HNF-36426

Revision 3

\title{
Slope Stability Evaluation and Equipment Setback Distances for Burial Ground Excavations
}

Prepared for the U.S. Department of Energy

Assistant Secretary for Environmental Management

Contractor for the U.S. Department of Energy under Contract DE-AC06-08RL14788

CH2MHILL

Plateau Remediation Company

P.O. Box 1600

Richland, Washington 99352 
HNF-36426

Revision 3

EDC \#: PRC-EDC-10-45817

\section{Slope Stability Evaluation and Equipment Setback Distances for Burial Ground Excavations}

Document Type: ES

Program/Project: WM

D. S. McShane

CH2M HILL Plateau Remediation Company

Date Published

March 2010

Prepared for the U.S. Department of Energy

Assistant Secretary for Environmental Management

Contractor for the U.S. Department of Energy

under Contract DE-AC06-08RL14788

CH2MHILL

Plateau Remediation Company

P.O. Box 1600

Richland, Washington

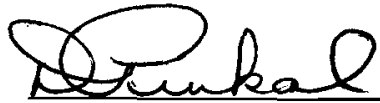

Release Approval

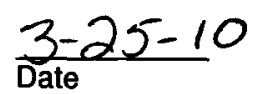

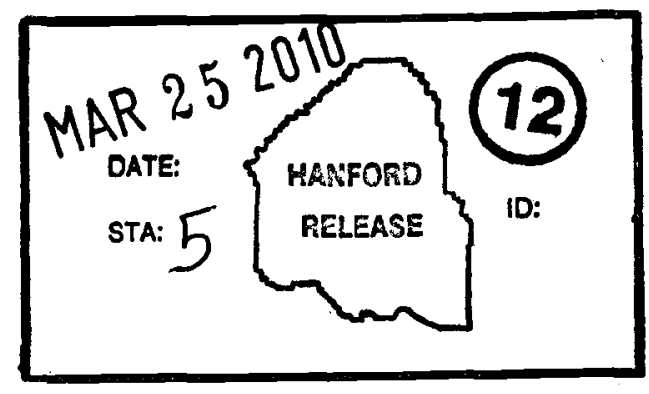

Release Stamp 
HNF-36426

Revision 3

TRADEMARK DISCLAIMER

Reference herein to any specific commercial product, process,

or service by trade name, trademark, manufacturer, or

otherwise, does not necessarily constitute or imply its

endorsement, recommendation, or favoring by the United

States Government or any agency thereof or its contractors or

subcontractors.

This report has been reproduced from the best available copy.

Printed in the United States of America

Total Pages:

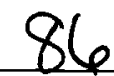

All trademarks contained within are the properties of the respective owners. 
(2) Title

Slope Stability Evaluation and Equipment Setback Distances for Burial Ground Excavations

Change Control Record

(3)

Revision

\begin{tabular}{|c|c|}
\hline 1 & $\begin{array}{l}\text { Page } 1 \text { Second Paragraph, add reference to Calculation } \\
300013-C-001 \text {. }\end{array}$ \\
\hline 1 & $\begin{array}{l}\text { Page } 3 \text { Section } 4.0 \text { revise first paragraph to account for all } \\
\text { heavy equipment used near the trenches. }\end{array}$ \\
\hline 1 & Add Attachement B \\
\hline 1 & Revistion 1 changes made per HNF-EDC-08-39923 \\
\hline 2 & Complete Revision per PRC-EDC-0943559 \\
\hline 3 & $\begin{array}{l}\text { Page } 3 \text { add Section } 2.3 \text { for setback distances was added as a } \\
\text { summary of the setback distances. }\end{array}$ \\
\hline 3 & Page 3 , what was section 2.3 was change to 2.4 . \\
\hline 3 & $\begin{array}{l}\text { Page } 6 \text { section } 2.4 .3 .2 \text { (changed from } 2.3 .3 .2 \text { ) the second } \\
\text { paragraph was added explaining the transitioning slopes. }\end{array}$ \\
\hline 3 & $\begin{array}{l}\text { On Pages } 4 \text { through } 11 \text { the text and figures were reformated due } \\
\text { to the additional text added on page } 3\end{array}$ \\
\hline $3 \mathbf{R S}$ & Revision 3 changes are made per PRC-EDC-10-45817 \\
\hline
\end{tabular}

Authorized for Release

(5) DATA Date

JRR

JRR

JRR

JRR

JRR

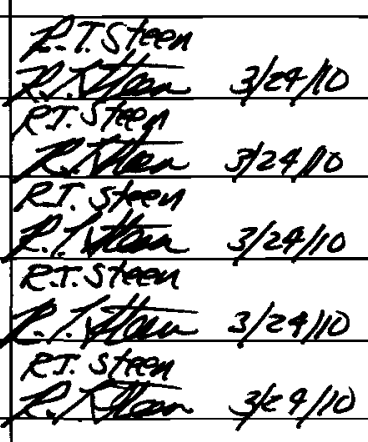




\section{Slope Stability Evaluation and Equipment Setback Distances \\ for \\ Burial Ground Excavations}

\subsection{Introduction}

After 1970 Transuranic (TRU) and suspect TRU waste was buried in the ground with the intention that at some later date the waste would be retrieved and processed into a configuration for long term storage. To retrieve this waste the soil must be removed (excavated). Sloping the bank of the excavation is the method used to keep the excavation from collapsing and to provide protection for workers retrieving the waste. The purpose of this paper is to document the minimum distance (setback) that equipment must stay from the edge of the excavation to maintain a stable slope. .

This evaluation examines the equipment setback distance by dividing the equipment into two categories, (1) equipment used for excavation and (2) equipment used for retrieval. The section on excavation equipment will also discuss techniques used for excavation including the process of benching. Calculations 122633-C-004, "Slope Stability Analysis" (Attachment A), and 300013-C-001, "Crane Stability Analysis" (Attachment B), have been prepared to support this evaluation. As shown in the calculations the soil has the following properties:

- Unit weight 110 pounds per cubic foot

- Friction Angle (natural angle of repose) $38^{\circ}$ or 1.28 horizontal to 1 vertical

Setback distances are measured from the top edge of the slope to the wheels/tracks of the vehicles and heavy equipment being utilized. The computer program utilized in the calculation uses the center of the wheel or track load for the analysis and this difference is accounted for in this evaluation.

\subsection{Excavating and Excavation Equipment:}

\subsection{Removal of Overburden}

Generally the waste trenches have four (4) to eight (8) feet of soil over the top of the waste containers. This soil layer (overburden) is provided to protect the environment from a release from the waste containers, protect the waste containers from the weather, and allow equipment traffic over the top of the trench. The overburden distributes the weight of the equipment to many containers which allows equipment traffic to pass over the trench safely. When excavation begins the confining effect from the overburden is removed and waste containers must be protected from the possibility of sliding or toppling into waste arrays. The protection is provided by keeping equipment back from the edge of the trench.

One of the load cases in the calculation determined the excavation equipment setback distance. This load case considered the weight of the heaviest piece of excavation equipment, the Komatsu® excavator, used for digging. Therefore, the results are applicable for all types of lesser weight equipment. In the calculation, the lateral soil pressure on the covered waste array was determined considering the excavator at different setback distances from the edge of the 
array. The calculation also determined the strength of a waste drum accounting for potential deterioration. When lateral pressure is compared to drum strength a setback distance of 3 feet- 6 inches (minimum) from the edge of the waste drum array yielded a factor of safety of 2.9 which is adequate. Figure 1 shows the configuration.

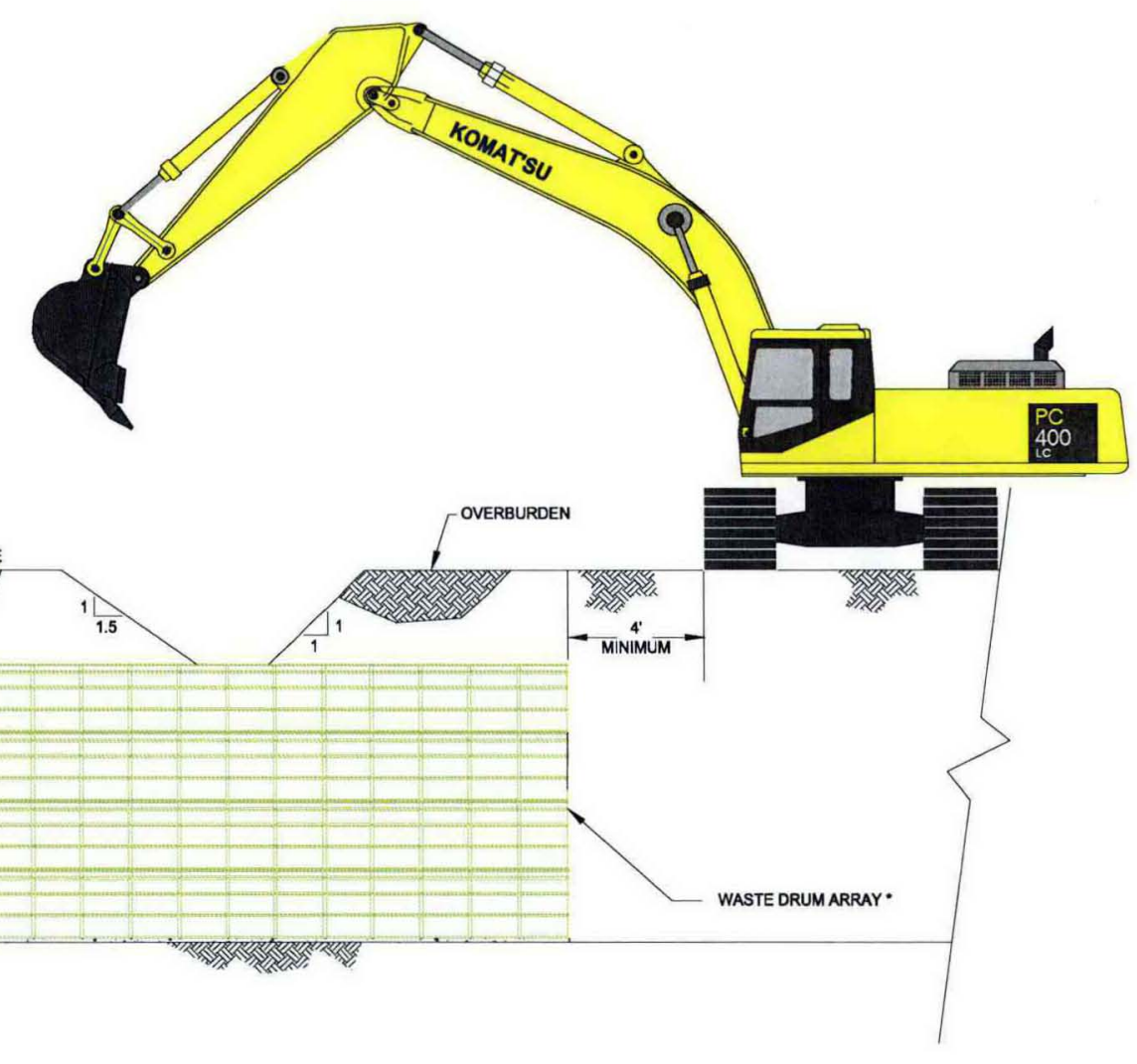

Figure 1

Removal of the Overburden

\subsection{Excavation for Retrieval:}

Once the overburden is removed and the waste array or containers are exposed, excavation begins to uncover the waste containers for retrieval. Since some of the waste containers are stacked on other containers excavation and retrieval may occur simultaneously. The depth of excavation can vary from 4 to 20 feet.

When excavating, the preferred method for slope stabilization is sloping with a side slope no steeper that a 1.5 horizontal to 1 vertical $(1.5 \mathrm{~h}$ to $1 \mathrm{v})$. Other methods of slope stabilization (i.e. shoring, shielding, etc.) could be used if necessary and will be evaluated on a case by case basis. The $1.5 \mathrm{~h}$ to $1 \mathrm{v}$ slope was selected because this is also the slope required for safe manned entry into the trench in accordance with OSHA criteria. When the side slope of a trench is shallower 
than or equal to $1.5 \mathrm{~h}$ to $1 \mathrm{v}$, manned entry is allowed in the trench at the same time that an excavator is working from the top of the trench.

Excavation to the deeper depths ( 12 feet to 20 feet) could require a steepened slope (as steep as $1 \mathrm{~h}$ to $1 \mathrm{v}$ ) for the excavator to reach the material to be removed. The calculation evaluated slope stability at different excavated depths and different slope angles. The results demonstrate that the equipment centerline should be behind the sloped line for the soil angle of repose. The natural angle of repose for the LLBG was determined by laboratory analysis as $38^{\circ}$ or $1.28 \mathrm{~h}$ to $1 \mathrm{v}$.

\subsection{Setback Distances}

To simplify development of excavation procedures for the Waste Retrieval Project, setback distances are limited to three conditions:

1. For the excavator when the tracks are perpendicular to the trench the setback distance is 0 feet for all slope angles (Maximum angle $1 \mathrm{~h}: 1 \mathrm{v}$ ).

2. For the excavator when the tracks are parallel to the trench the following is allowed:

- While excavating with a slope angle $1.5 \mathrm{~h}: 1 \mathrm{v}$ or shallower the set back distance is 0 feet from the edge of the track.

- While excavating with a slope angle steeper than $1.5 \mathrm{~h} \mathrm{:} 1 \mathrm{v}$ (maximum angle is $1 \mathrm{~h}: 1 \mathrm{v})$ the set back distance is 4 feet.

- When reducing the slope form $1 \mathrm{~h}: 1 \mathrm{v}$ (maximum) to a slope of $1.5 \mathrm{~h}: 1 \mathrm{v}$, the setback distance to the edge of the track shall start at 4 feet. During this transition the setback distance maybe reduce to 0 feet (edge of the track).

3. For all other equipment (i.e. water trucks, cranes, golf carts, etc.), the setback distance is 4 feet.

\subsection{Methodology Used to Determine Setback Distances}

The setback distances were selected based on the attached calculations. The calculations demonstrate that the setback distance is a function of the angle of the side slope and the natural angle of repose $\left(38^{\circ}\right)$. Figure 2 was developed to graphically show the relationship between the different angles evaluated. The slope that controls the slope stability is the natural angle of repose or $1.28 \mathrm{~h}: 1 \mathrm{v}\left(38^{\circ}\right)$. The setback distances are controlled by a slope of $1 \mathrm{~h}: 1 \mathrm{v}\left(45^{\circ}\right)$. The following sections explain the rational used to develop the setback distances. 


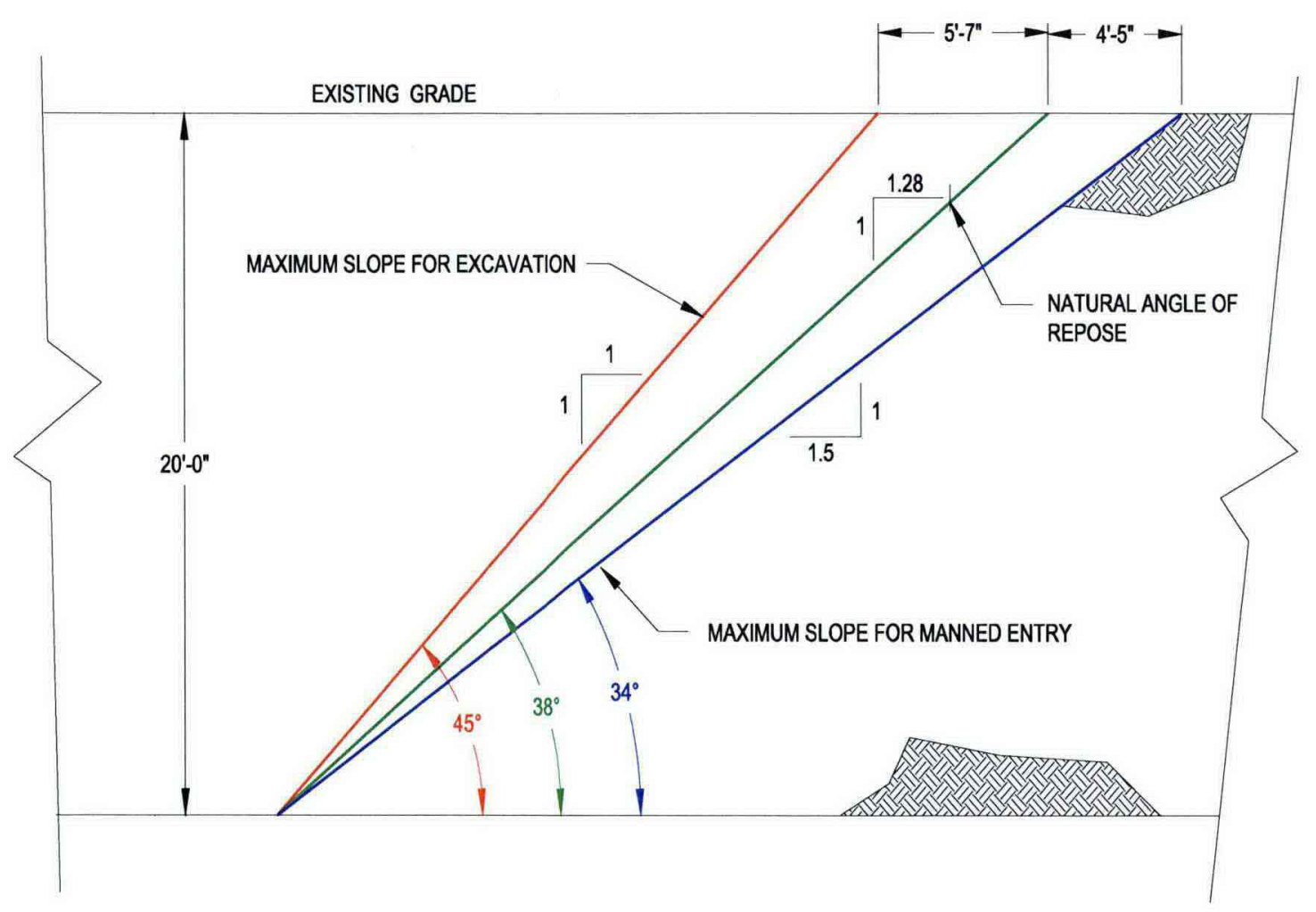

Figure 2

Comparison of Evaluated Slopes

\subsubsection{Side Slope 1.5 horizontal to 1 vertical}

The angle for a side slope $1.5 \mathrm{~h}$ to $1 \mathrm{v}\left(34^{\circ}\right)$ is less than the natural angle of repose (Figure 2) and is very stable. The calculation shows that the only effect any of the equipment has on a slope of this angle is some minor compaction of the top of the slope. When the tracks of the excavator are perpendicular they could extend over the top of the slope by two or three feet and the slope would still be stable.

\subsubsection{Natural Angle of Repose (38 $)$}

The natural angle of repose for this material is $38^{\circ}$ or $1.28 \mathrm{~h}$ to $1 \mathrm{v}$. The calculation shows that this angle controls the stability of the slope for this soil. Therefore the weight of the equipment should always stay behind this line. This angle will be used to calculate the setback distances.

\subsubsection{Side Slope 1 horizontal to 1 vertical $\left(45^{\circ}\right)$}

The slope of $1 \mathrm{~h}$ to $1 \mathrm{v}$ is the maximum slope needed for the excavator to reach depths to 20 feet. This slope only remains as long as necessary to achieve the trench depth required. Once the depth is obtained the side slopes are reduced to the $1.5 \mathrm{~h}$ to $1 \mathrm{v}$ for personnel entry. 


\subsubsection{Setback distance for the excavator when the tracks are perpendicular to the excavation:}

Figure 3 shows an example of this configuration. The calculation concludes that the center of the track should always be behind the slope for the natural angle of repose. In this configuration the center of the track is the center line of the excavator. Measuring to the center of the excavator can lead to confusion so to simplify, the setback distance will be measured from the top of the limiting slope $(1 \mathrm{~h}: 1 \mathrm{v})$ to the point where the track is closest to the excavation (see Figure 3 ). The setback is then determined as distance from the top edge of the $1 \mathrm{~h}$ tolv slope and top of the 1.28:1 slope ( 5 foot -7 inches) minus $1 / 2$ of the length of the track ( 17 foot- 7 inches $\div 2=8$ feet $-91 / 2$ inches) which is a negative distance. A negative distance will not be allowed so the setback distance will be 0 (the tracks can come right up to the trench edge on the limiting $1 \mathrm{~h}: 1 \mathrm{v}$ slope.

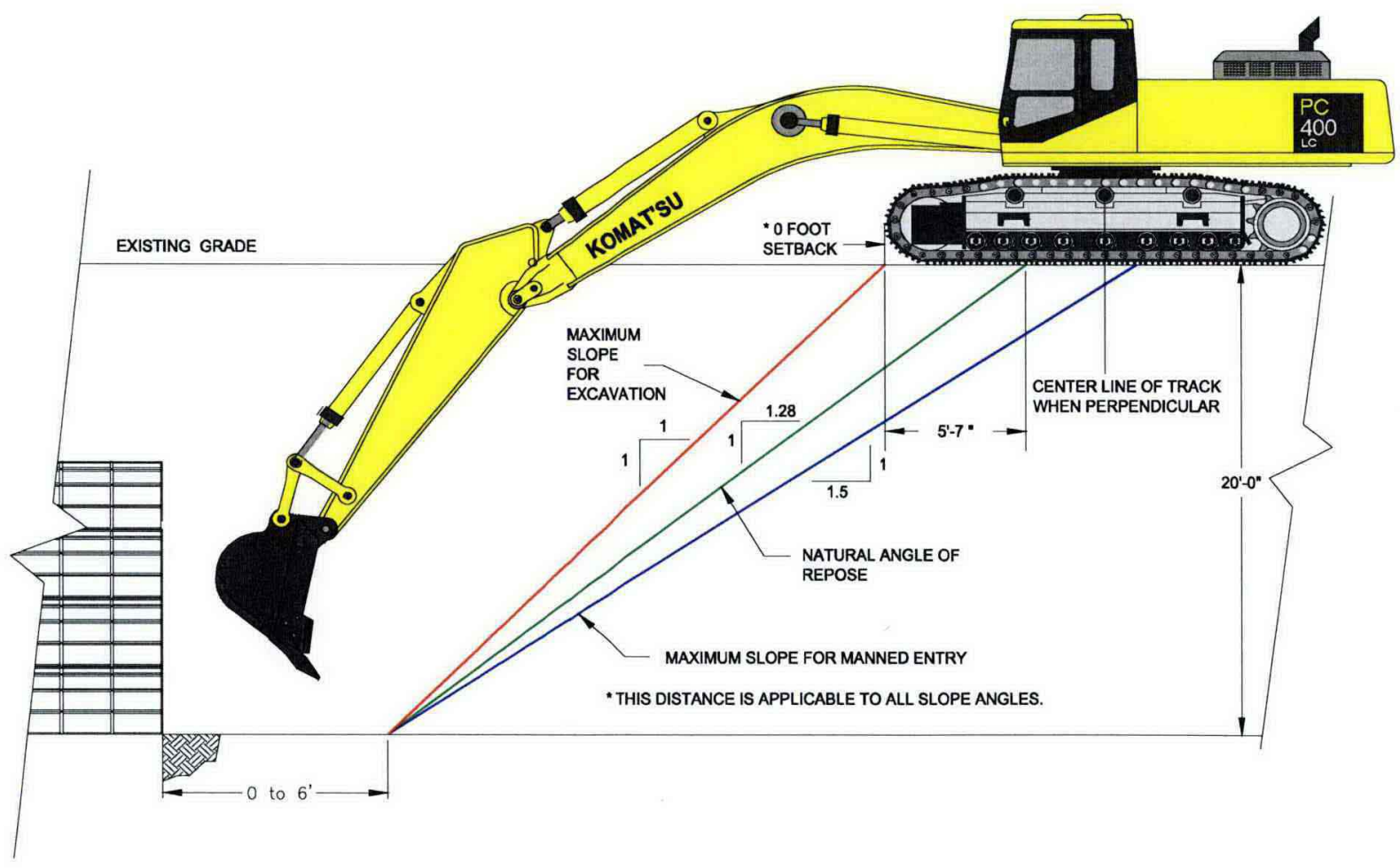

Figure 3

Excavation with the Excavator Tracks Perpendicular 


\subsubsection{Setback distance for the excavator when tracks are parallel to the excavation:}

Figure 4 shows an example of this configuration. The calculation concludes that the center of the track should always be behind the slope for the natural angle of repose. Measuring to the center of the track can lead to confusion so to simplify, the setback distance will be measured from the top of the limiting slope (1h tolv) to the edge of the track closest to the excavation. The setback distance is then the distance between the top of the $1 \mathrm{~h}$ to $1 \mathrm{v}$ slope and top of the $1.28 \mathrm{~h}$ to $1 \mathrm{v}$ slope ( 5 foot -7 inches) minus $1 / 2$ of the track width ( 3 foot $\div 2=1$ foot- 6 inches) which equals 4 foot- 1 inches (to simplify use 4 feet). For slopes with an angle shallower than the $1.28 \mathrm{~h}: 1 \mathrm{v}$ the set back distance for the parallel condition can be 0 feet.

Once the trench has been excavated to the desired depth the angle of the side slope is transitioned from the $1 \mathrm{~h}: 1 \mathrm{v}$, needed for excavation, to a slope of $1.5 \mathrm{~h}: 1 \mathrm{v}$ which is required for manned entry. As can be seen in Figure 4 the setback distance, for transition, can start at 4 feet from the top of slope to the edge of the closest track and be reduced to 0 feet (to the edge of the track) as the slope angle is reduced. This is acceptable since the center line of the track will always be at or behind the slope of the natural angle of repose ( $1.28 \mathrm{~h}$ to $1 \mathrm{v})$.

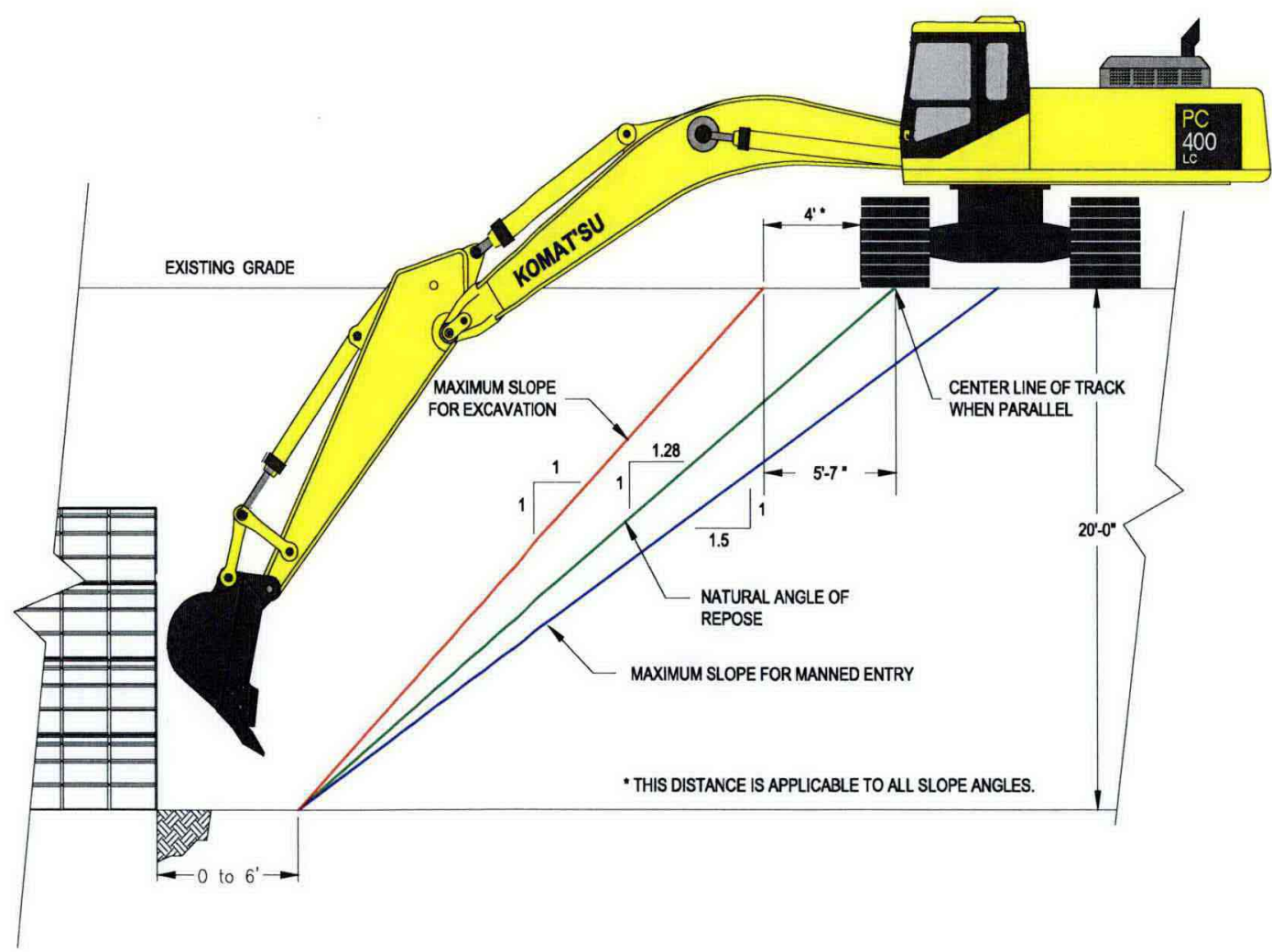

Figure 4

Excavating with the Excavator Tracks Parallel 
HNF-36426

Revision 3

\subsubsection{Other Equipment Used for Excavation}

There are several other pieces of equipment that are utilized during excavation (i.e. dump trucks, water trucks, front end loaders, etc.) The calculation concludes that these pieces of equipment should also stay behind the slope for the natural angle of repose. Due to the configuration of this type of equipment the setback distance is the same as whether the piece of equipment operates parallel or perpendicular to the trench. The setback is the distance between the top of the limiting 1:1 slope and top of the 1.28:1 slope (5 foot -7 inches) minus $1 / 2$ of the width or a set for dual tires similar to the rear tires on the water truck. ( 3 foot $\div 2=1$ foot-6 inches) which is approximately 4 feet (See figure 5).

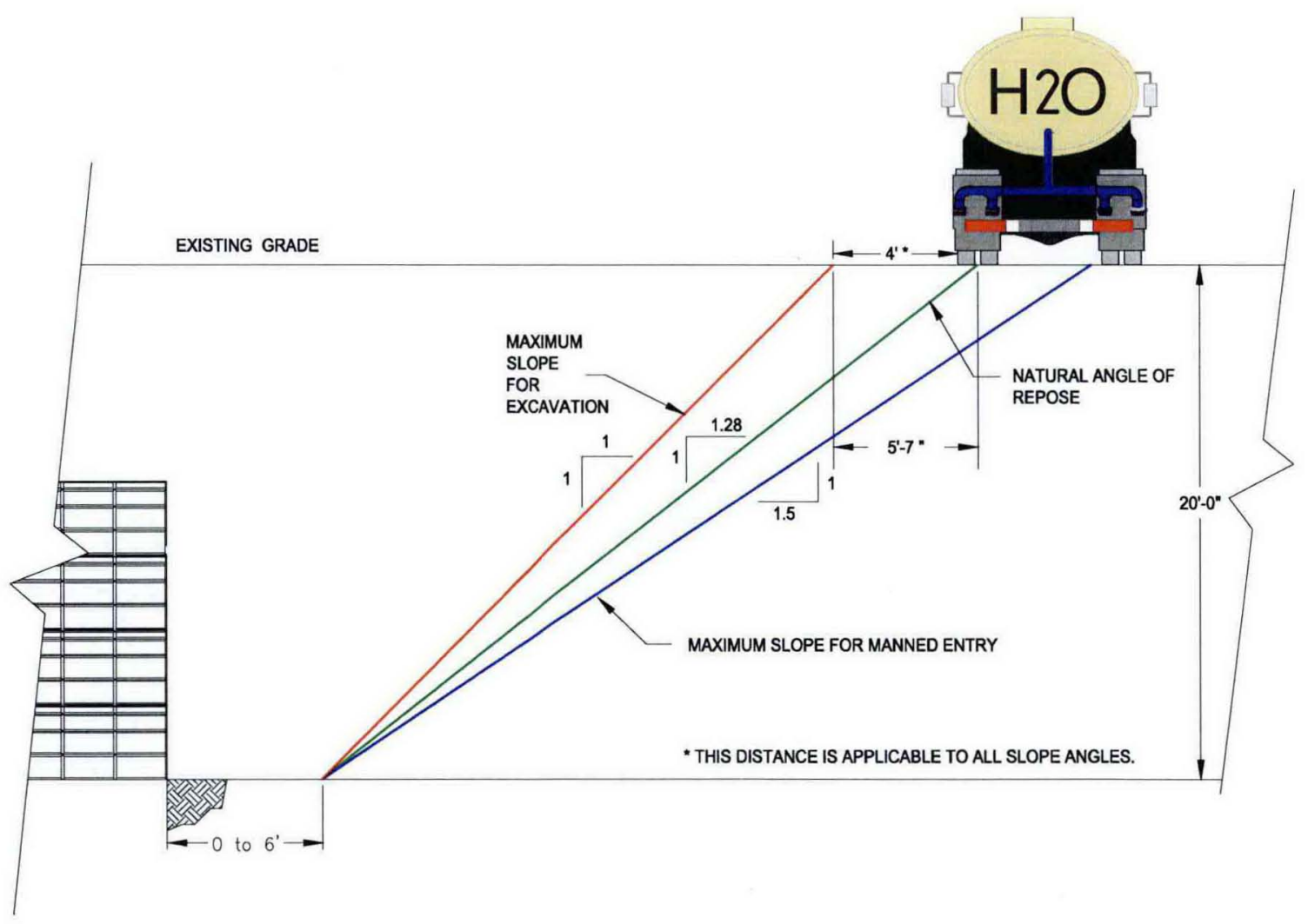

Figure 5

Setback Distance for All Other Type of Equipment 
HNF-36426

Revision 3

\subsubsection{Benching}

Benching is a technique used to maintain slope stability and allow an excavator to reach areas that are too deep for the size of the excavator from the top of the trench.

\subsubsection{Benching for slope stability}

This type of benching is common for slopes that are perpendicular to the center line of the trench. This technique is covered in the excavation standard, 29 CFR 1926.650 Subpart P. From this section the definition of benching is "a method of protecting employees from cave-ins by excavating the sides of an excavation to form one or a series of horizontal levels or steps, usually with a vertical or near vertical surfaces between levels". Figure 6, Section A-A shows how perpendicular benching is done. Note in the Section View that the slope ultimately is $1.5 \mathrm{~h}$ to $1 \mathrm{v}$.

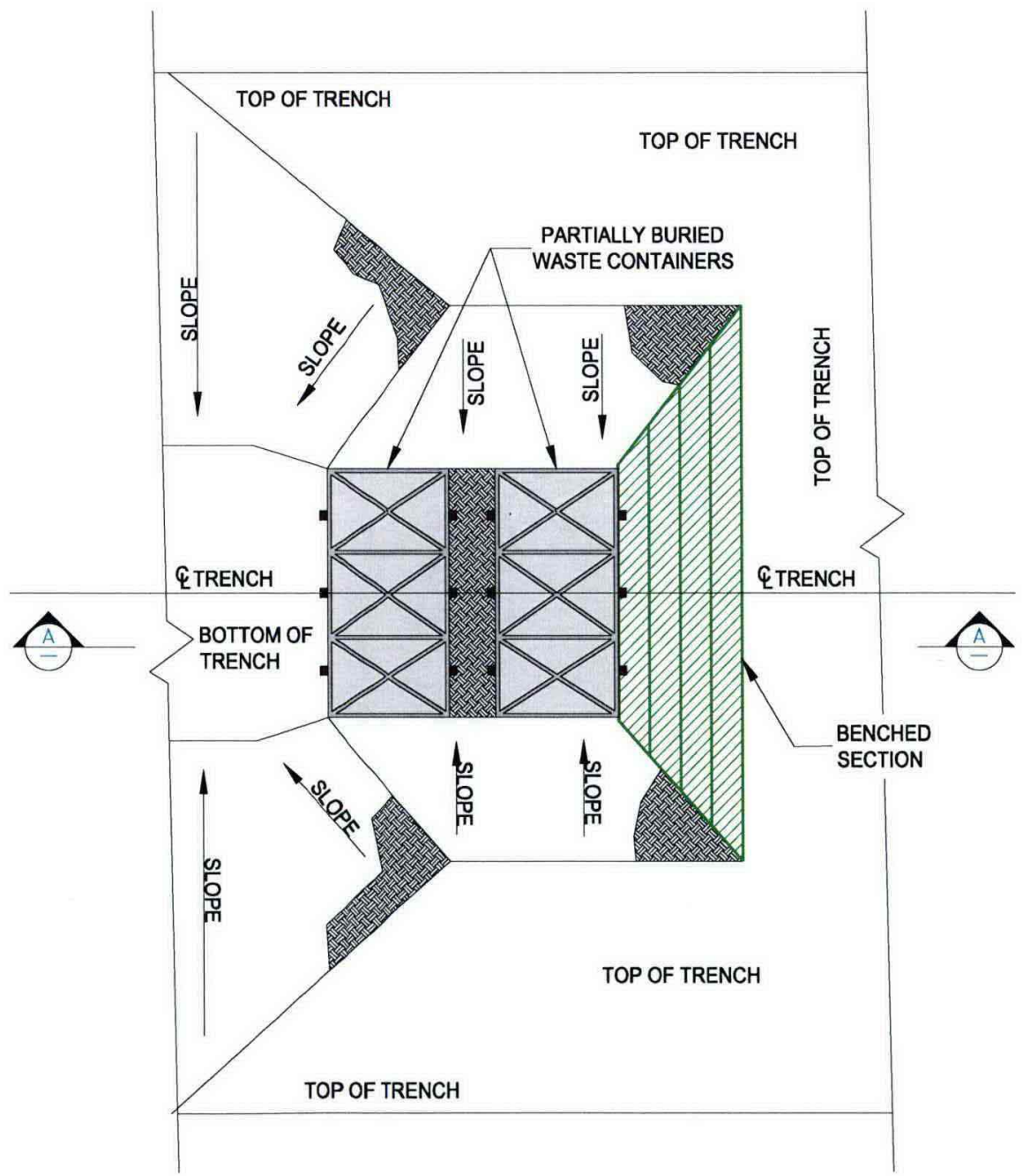

Figure 6 Perpendicular Benching 
HNF-36426

Revision 3

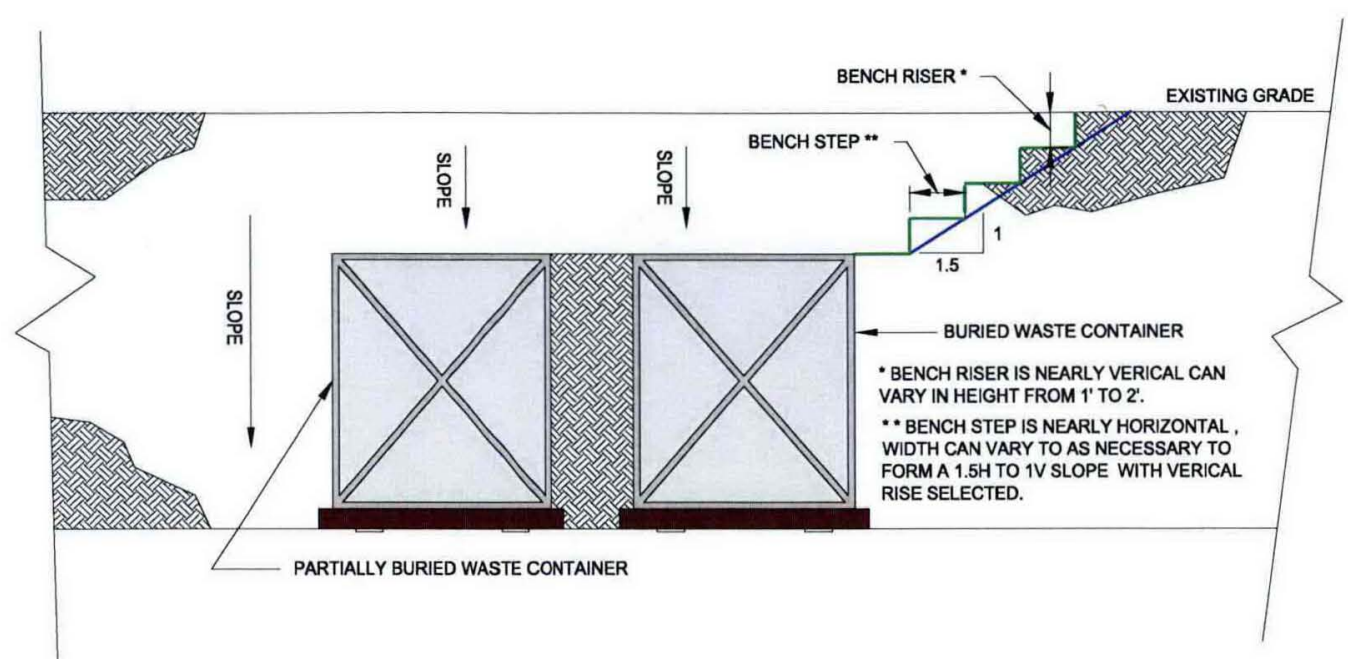

Figure 6 Perpendicular Benching continued

\subsubsection{Benching to aid in hard to reach areas}

This type of benching is when excavating at a steep slope (e.g. 1h to 1v) is not feasible. Generally this condition is present when manned entry is needed either to retrieve upper level waste containers or perform hand excavation. In this situation the benching lowers the level at which the excavator is placed allowing it to be closer to the work. Figures 7 and 8 have been prepared to illustrate benching. Note the excavator is shown operating from a level base. This is for reference only, the slope that the excavator operates from is limited by the capability of the excavator to operate on a sloped surface and not the stability of the side slope. The slope stability and setback distances are the same as the excavation when benching is not used. Note the slope at the back of the bench is a function of the depth of the bench. 
HNF-36426

Revision 3

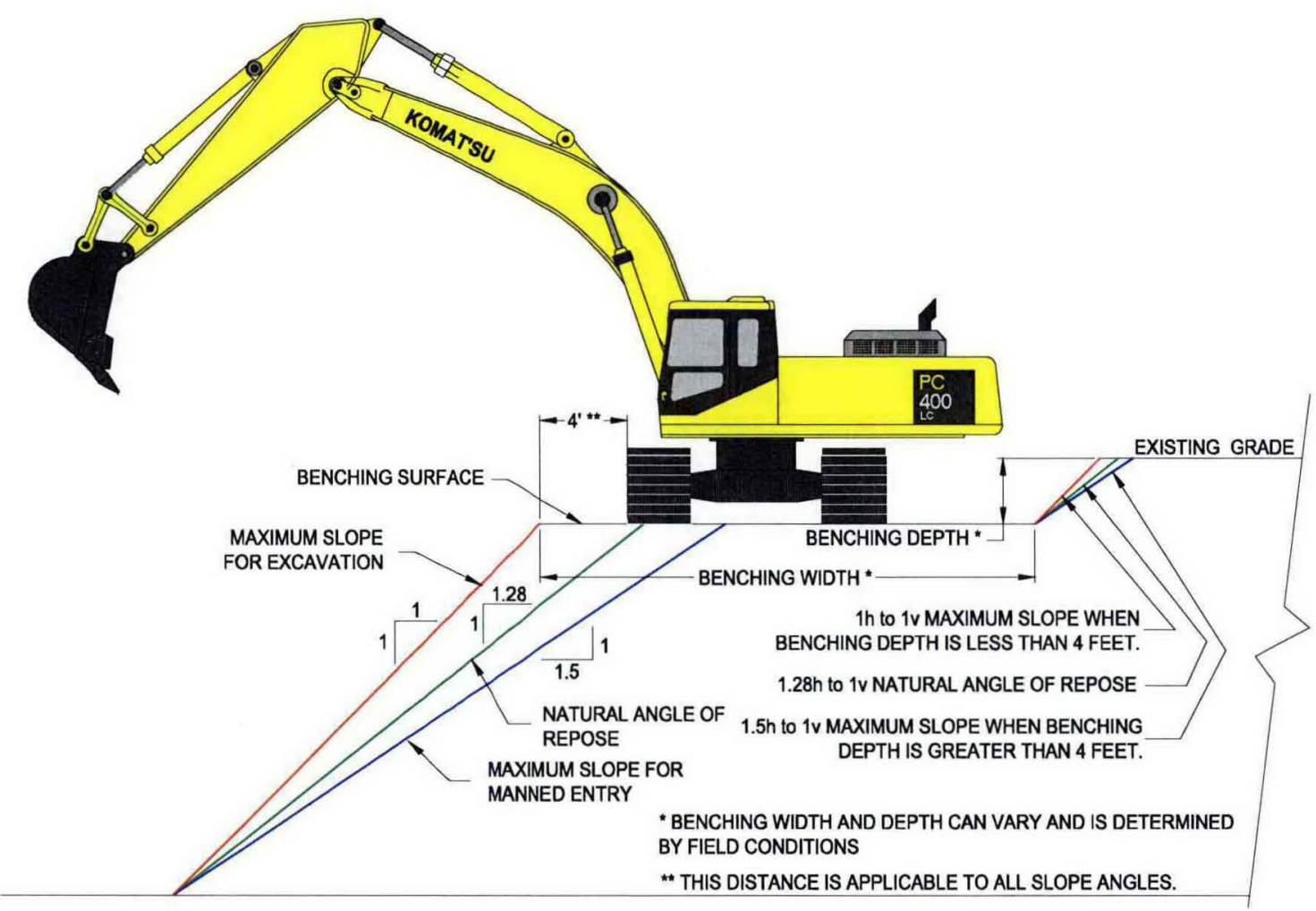

Figure 7

Benching with Excavator Tracks Parallel

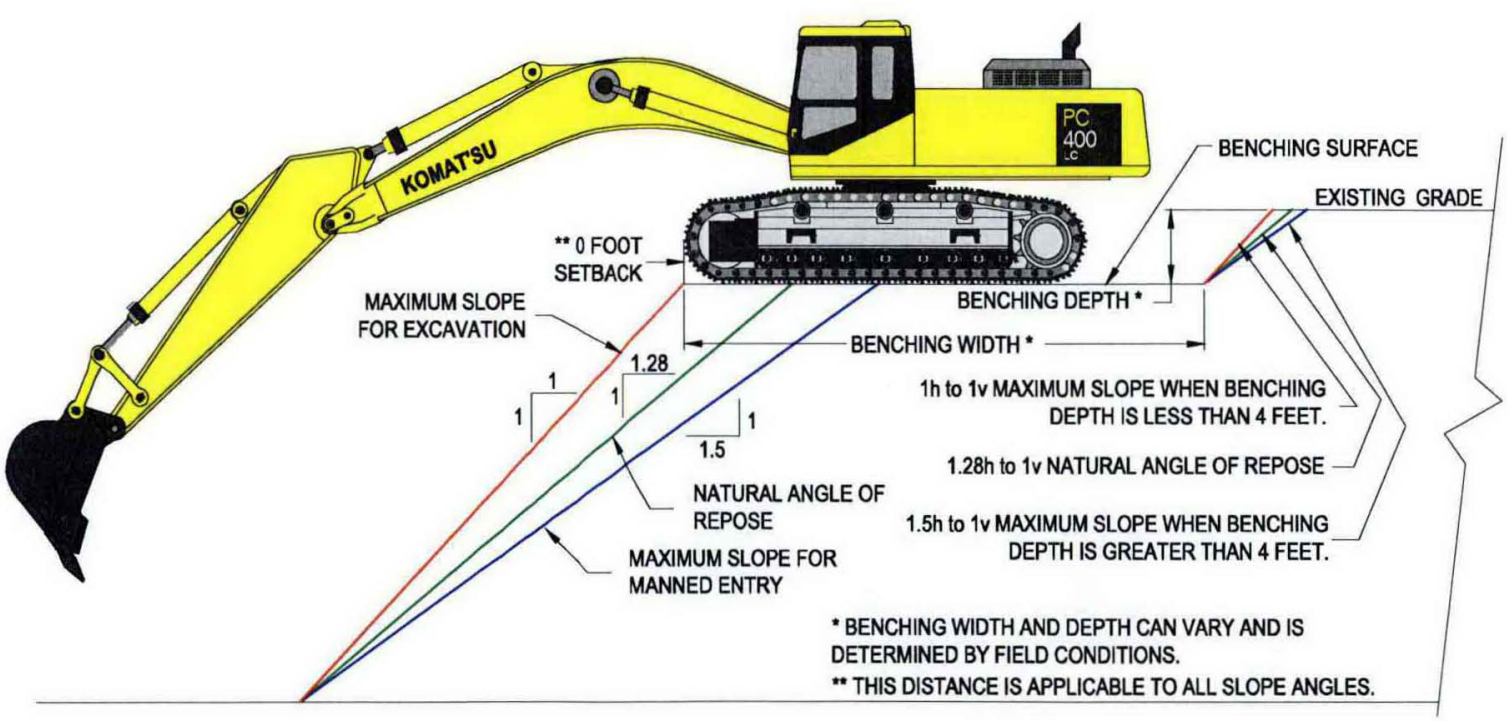

Figure 8

Benching with Excavator Tracks Perpendicular 


\subsubsection{Excavator stability associated with trench excavation}

The specifications for the Komatsu excavators operated in the burial grounds indicate that the excavators can climb or descend a $35^{\circ}$ slope (This is just slightly steeper than a $1.5 \mathrm{~h}$ : 1v slope). They recommend performing excavation operations on a slope of $30^{\circ}$ maximum. For conservatism it is recommended that excavators operate from an approximately level grade (when on a bench or otherwise). For ease of identification in the field, a slope of $\pm 5^{\circ}$, which corresponds to "visually level", would be adequate.

\subsection{Equipment Used for Retrieval}

Equipment used to retrieve waste containers vary from heavy cranes (tracked or rubber tired) to light weight golf carts. The calculations (Appendix A and B) demonstrate that from a slope stability aspect the $1.5 \mathrm{~h}$ to $1 \mathrm{v}$ slope, required for manned entry, would be stable if any of the equipment (i.e. water truck, front end loaders, track and rubber tire cranes, ect.) were to be operated directly at the top edge of the slope. The only affect on the soil would be some minor localized compaction at the top of the slope. However, from an industrial safety perspective (e.g. a worker exiting a vehicle and falling down the slope) the establishment of a setback distance is prudent. An example setback distance of 4 feet is shown in Figure 9; this example is not based on soil stability (for which no setback is required with the $1.5 \mathrm{H}: 1 \mathrm{~V}$ slope) but is based only on worker safety considerations.

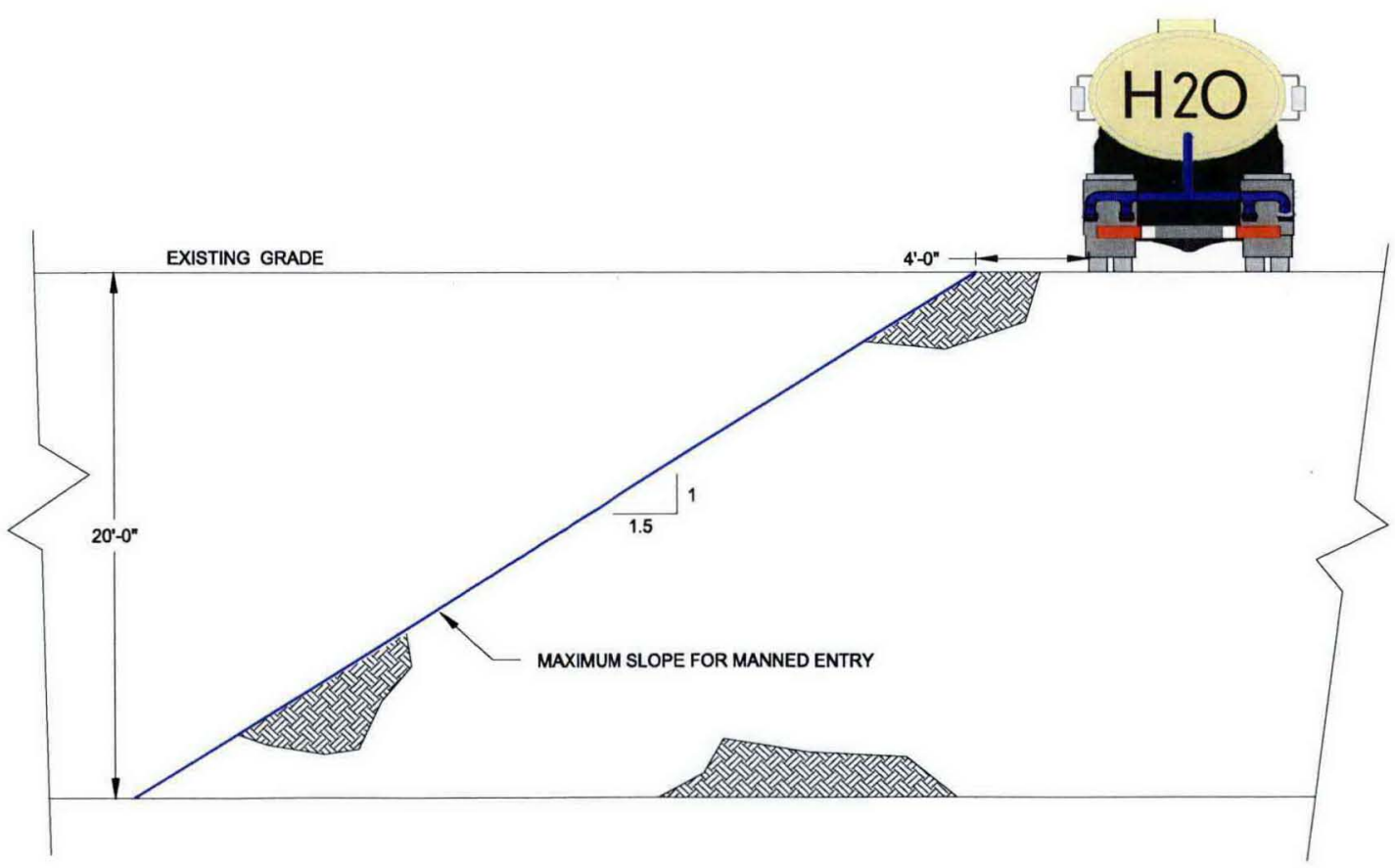

Figure 9

Equipment Setback Distance for Equipment used for Retrieval 
Attachment A

Calculation 122633-C-004 


\section{Calculation Cover Sheet and Revision Summary}

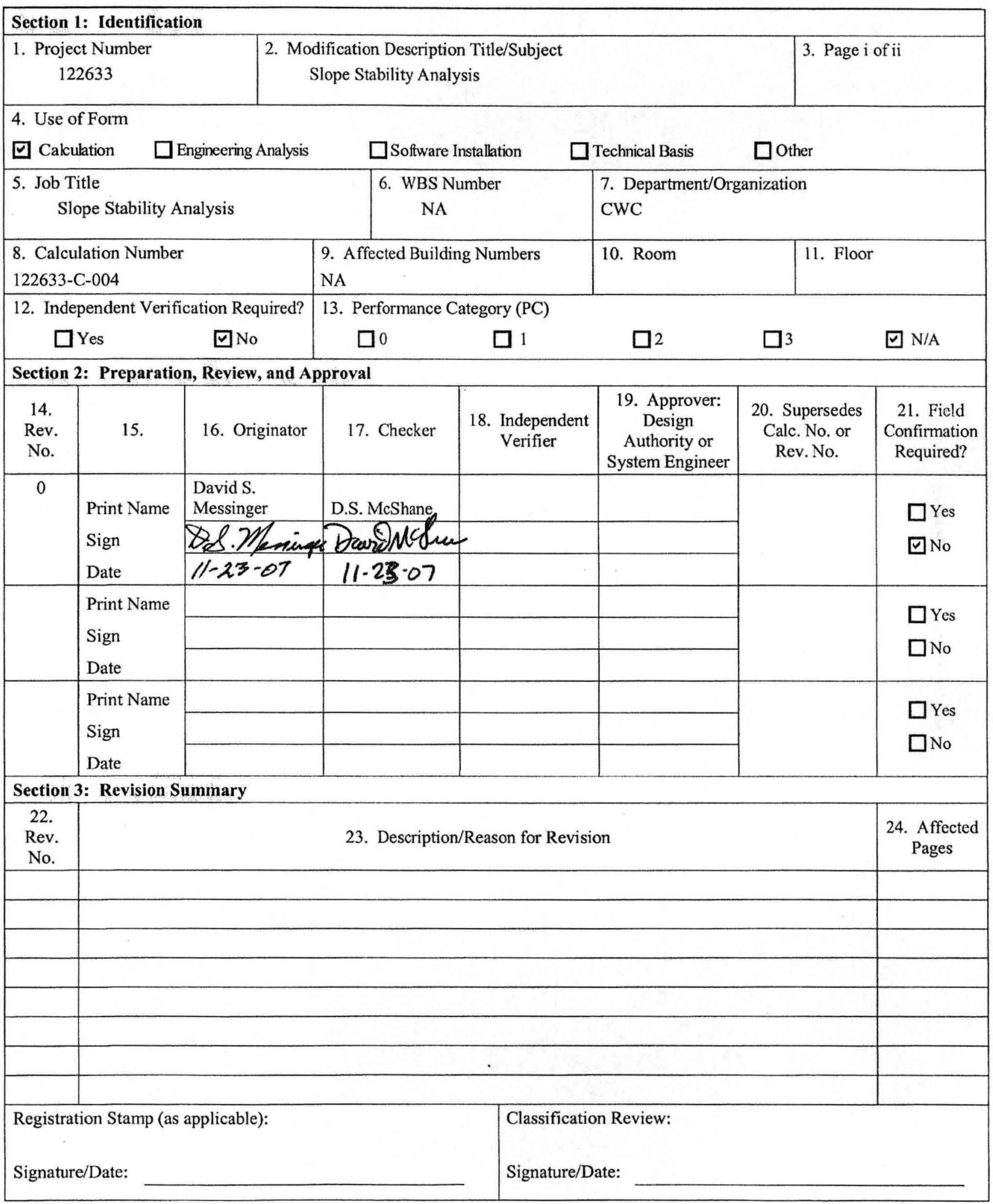




\section{Calculation/Technical Basis Sheet}

\begin{tabular}{|l|l|l|}
\hline Section 1: Identification & 3. Page ii \\
\hline $\begin{array}{l}\text { 1. Project Number } \\
\text { 122633 }\end{array}$ & $\begin{array}{l}\text { 2. Modification Description Title/Subject } \\
\text { Slope Stability Analysis }\end{array}$ & 5. Rev. No. \\
\hline $\begin{array}{l}\text { 4. Calculation Number } \\
\text { 122633-C-004 }\end{array}$ & \\
\hline Section 2: Scope, Objective, Method, Assumptions, Technical Basis & $\begin{array}{l}\text { 6. Scope and Objective } \\
\text { This calculation was performed to support safe excavation operations connected with drum retrieval in trenches at } \\
\text { the Central Waste Facility in the 200 West Area. There were six configurations presented with three different } \\
\text { loading situations to evaluate. The loadings are given in the assumption section below. The configurations are } \\
\text { shown in the figures. }\end{array}$
\end{tabular}

\section{Method}

Hand calculation using MathCad 14.0 MO11 and Slope stability analysis using the interactive computer program STB2006. STB2006 was developed at Delft University and Verified by FGG. This program uses Bishops simplified method to determine the minimum factor of safety. The approved for use form is included in the appendix.

8. Assumptions and Technical Basis

1. The soil weight is assumed to be about 110 pcf. This is a reasonable for the area of interest. The soils to be excavated contain gravel and are heavier than the sand from Ref. 1.

2. The angle of internal friction for the soil is 380 . (Ref. 1)

3. The dry soil is cohesionless but has an apparent cohesion of between $11 \mathrm{psf}$ and $14 \mathrm{psf}$ when freshly excavated allowing the newly excavated slope to stand at $1 \mathrm{H}: 1 \mathrm{~V}$.

4. The excavator tracks are 31.5 inches wide, spaced 7'-7" c-c and exert a ground loading of 3,300 lbs/ft of track length.

5. Assume the bulk Poisson ratio for the soil, $\mu:=0.33$ (Ref. 5 , Table 2-7).

6. Calculation was to determine equipment distances for $1: 1$ factors of safety. (1.1:1 minimum recommended)

Section 3: Design Inputs/References

\begin{tabular}{|l|l|}
\hline 9. Ref. No. & \multicolumn{1}{|c|}{ 10. Inputs/References (with Revision and/or Date or Source) } \\
\hline 1 & Site Investigation Report WHC-SD-W025-SE-001 \\
\hline 2 & Roark's Formulas for Stress and Strain, 7th Edition, McGraw Hill \\
\hline 3 & Advanced Soil Mechanics, 2nd Edition, Das, Taylor and Francis, New York, NY \\
\hline 4 & Foundation Analysis and Design, 5th Edition, Bowles, McGraw Hill \\
\hline \multicolumn{2}{|l|}{ Section 4: Conclusions }
\end{tabular}

1. (Load Case 1) The tracked excavator can operate with the edge of the closest track within $3.5^{\prime}$ of the face of the drum stack.

2. For the 4' and 7' deep excavation at 1:1 slope the excavator should be at least 3' from the top of the slope.

3. For the $10^{\prime}$ and $13^{\prime}$ deep excavation at $1: 1$ the excavator should be at least $4^{\prime}$ from the top of the slope.

4. For the $16^{\prime}$ deep excavation at 1:1 slope the excavator should be at least 5 ' from the top of the slope.

5. The $38 \mathrm{deg}$. angle of repose is a $1.28 \mathrm{H}: 1 \mathrm{~V}$ slope. The excavator should always be behind that slope line.

6. For the $16^{\prime}$ deep excavation sloped at $1.5 \mathrm{H}: 1 \mathrm{~V}$, the excavator should be at least 2 from the top of the slope.

7. The $\mathrm{H}-20$ tandem axle truck should not operate closer than $4^{\prime}$ from the top of the 1.5:1 slope. 
Fluor Hanford, Inc.

Client: Fluor Hanford

Subject: Slope Stability Analysis for

Exavation Work At CWC Trench

Location: CWC 200W

\section{ENGINEERING ANALYSIS}

Calc. No.:122633-C-004 Revision: 0

Page No.: 1 of 9

T.O./Job No.: 65400811.122633

\section{OBJECTIVE:}

This calculation was performed to support safe excavation operations connected with drum retrieval in trenchs at the Central Waste Facility in the 200 West Area. There were six configurations presented with three different loading situations to evaluate. The loadings are given in the assumption section below. The configurations are shown in the figures.

\section{REFERENCE:}

1. Site Investigation Report WHC-SD-W025-SE-001

2. Roark's Formulas for Stress and Strain, 7th Edition, McGraw Hill

3. Advanced Soil Mechanics, 2nd Edition, Das, Taylor and Francis, New York, NY

4. Foundation Analysis and Design, 5th Edition, Bowles, McGraw Hill

\section{METHOD:}

Hand calculation using MathCad 14.0 MO11 and Slope stability analysis using the interactive computer program STB2006. STB2006 was developed at Delft University and Verified by FGG. This program uses Bishops simplified method to determine the minimum factor of safety. The approved for use form is included in the appendix.

\section{ASSUMPTIONS AND LIMITATIONS:}

1. The soil weight is assumed to be about $110 \mathrm{pcf}$. This is a reasonable for the area of interest. The soils to be excavated contain gravel and are heavier than the sand from Ref. 1.

2. The angle of internal friction for the soil is $38^{\circ}$. (Ref. 1)

3. The dry soil is cohesionless but has an apparent cohesion of between $11 p s f$ and $14 p s f$ when freshly excavated allowing the newly excavated slope to stand at $1 \mathrm{H}: 1 \mathrm{~V}$.

4. The excavator tracks are 31.5 inches wide, spaced $7^{\prime}-7^{\prime \prime} \mathrm{c}-\mathrm{c}$ and exert a ground loading of $3,300 \mathrm{lbs} / \mathrm{ft}$ of track length.

5. Assume the bulk Poisson ratio for the soil, $\mu:=0.33$ (Ref. 5, Table 2-7).

6. Calculation was to determine equipment distances for $1: 1$ factors of safety. (1.1:1 minimum recommended)

\section{CONCLUSION:}

1. (Load Case 1) The tracked excavator can operate with the edge of the closest track within $3.5^{\prime}$ of the face of the drum stack.

2. For the 4' and $7^{\prime}$ deep excavation at 1:1 slope the excavator should be at least $3^{\prime}$ from the top of the slope.

3. For the $10^{\prime}$ and $13^{\prime}$ deep excavation at $1: 1$ the excavator should be at least $4^{\prime}$ from the top of the slope.

4. For the $16^{\prime}$ deep excavation at 1:1 slope the excavator should be at least $5^{\prime}$ from the top of the slope.

5. The $38 \mathrm{deg}$. angle of repose is a $1.28 \mathrm{H}: 1 \mathrm{~V}$ slope. The excavator should always be behind that slope line.

6. For the $16^{\prime}$ deep excavation sloped at $1.5 \mathrm{H}: 1 \mathrm{~V}$, the excavator should be at least 2 ' from the top of the slope.

7. The $\mathrm{H}-20$ tandem axle truck should not operate closer than 4 ' from the top of the 1.5:1 slope.

\section{CALCULATIONS:}

\section{Definitions of Terms:}

Track half-width, $\mathrm{b}:=\frac{31.5}{2}$ in

Soil unit weight, $\gamma:=110 \mathrm{pcf}$
Excavator ground pressure, $q:=\frac{3300 \frac{\mathrm{lbf}}{\mathrm{ft}}}{2 \cdot \mathrm{b}}=8.73 \cdot \mathrm{psi}$

Internal friction angle of soil, $\phi:=38 \mathrm{deg}$ 
Fluor Hanford, Inc.

Client: Fluor Hanford Subject: Slope Stability Analysis for Exavation Work At CWC Trench Location: CWC 200W
ENGINEERING

ANALYSIS
Calc. No.:122633-C-004

Revision: 0

Page No.: 2 of 9

Originated by: D.S. Messinger, P.E.DSAMeingen Date: $11-13.07$ Checked by: David S. McShane, P.E. D.S.MC Heee Date: $1(-23 \cdot 0)$

Active earth pressure coefficient, $\mathrm{K}_{\mathrm{A}}:=\tan \left(45 \mathrm{deg}-\frac{\phi}{2}\right)^{2}=0.238$

At Rest earth pressure coefficient, $\mathrm{K}_{0}:=1-\sin (\phi)=0.384$

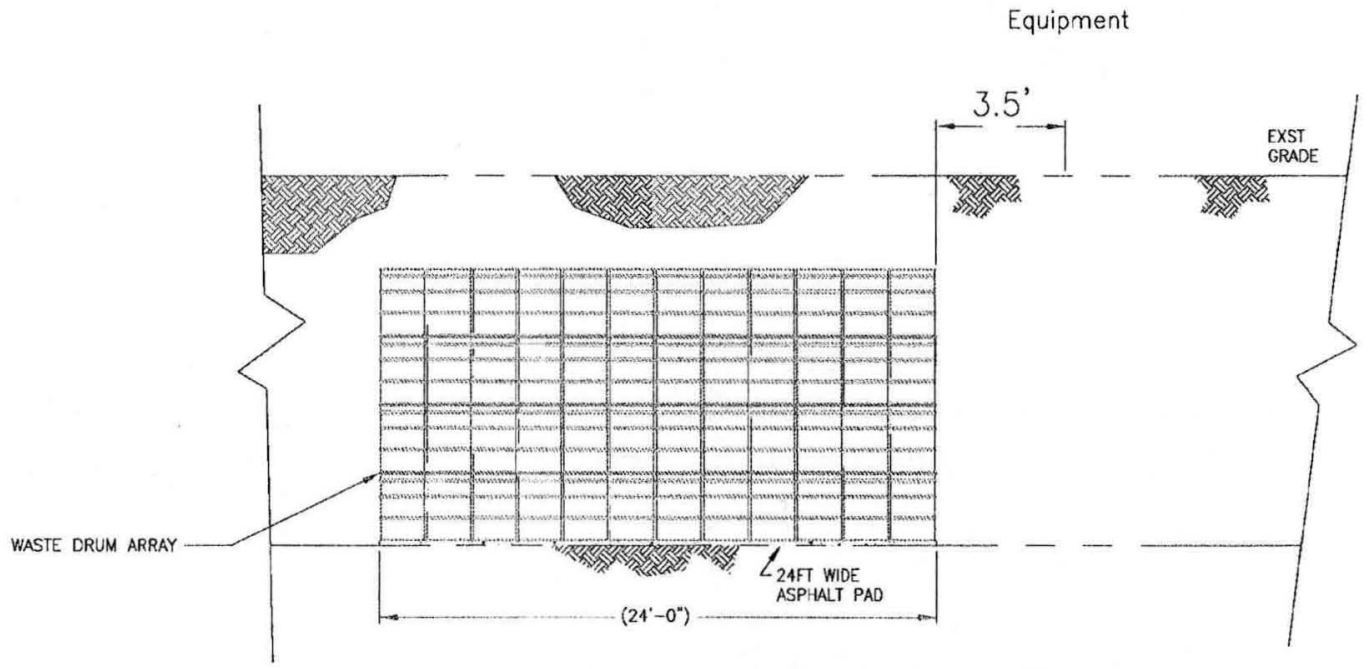

LOAD CASE 1 BEGIN EXCAVATION OF TRENCH OVERBURDEN

Load case 1 is to determine the safe lateral distance from the drum stack for excavation equipment.

The Boussinesq equation for a point load can be written as $\sigma_{r}:=\frac{P}{2 P}\left(\frac{3 r^{2} z}{R^{5}}-\frac{1-2 \mu}{R(R+z)}\right)$. For a strip loading condition, the plane strain Poisson ratio is used rather than the bulk Poisson ratio. The expression for the plane strain Poisson ratio is $\mu^{\prime}:=\frac{\mu}{1-\mu}=0.493 \quad 1-2 \mu^{\prime}=0.015$ or nearly zero and can be ignored in the following functions. (Ref. 4, Eq. 11-20a.)

Expressions for the vertical and horizontal soil pressure, are shown below as functions.

$$
\begin{array}{ll}
\sigma_{z}(x, z):=2 \frac{q}{\pi} \cdot \int_{-b}^{b} \frac{z^{3}}{\left[(x-s)^{2}+z^{2}\right]^{2}} d s \quad \sigma_{z}(5 f t, 4 f t)=86.032 \cdot p s f \\
\sigma_{x}(x, z):=\frac{2 q}{\pi} \cdot \int_{-b}^{b} \frac{(x-s)^{2} \cdot z}{\left[(x-s)^{2}+z^{2}\right]^{2}} d s & \sigma_{x}(5 f t, 4 f t)=123.029 \cdot p s f
\end{array}
$$




\section{Fluor Hanford, Inc.}

Client: Fluor Hanford

Subject: Slope Stability Analysis for

Exavation Work At CWC Trench

Location: CWC 200W
ENGINEERING ANALYSIS
Calc. No.:122633-C-004

Revision: 0

Page No.: 3 of 9

T.O./Job No.: 65400811.122633

Originated by: D.S. Messinger, P.E.D. D. PPJensine Date: $1 /-23.07$

Checked by: David S. McShane, P.E. Dand MCdue Date: $11.23-07$

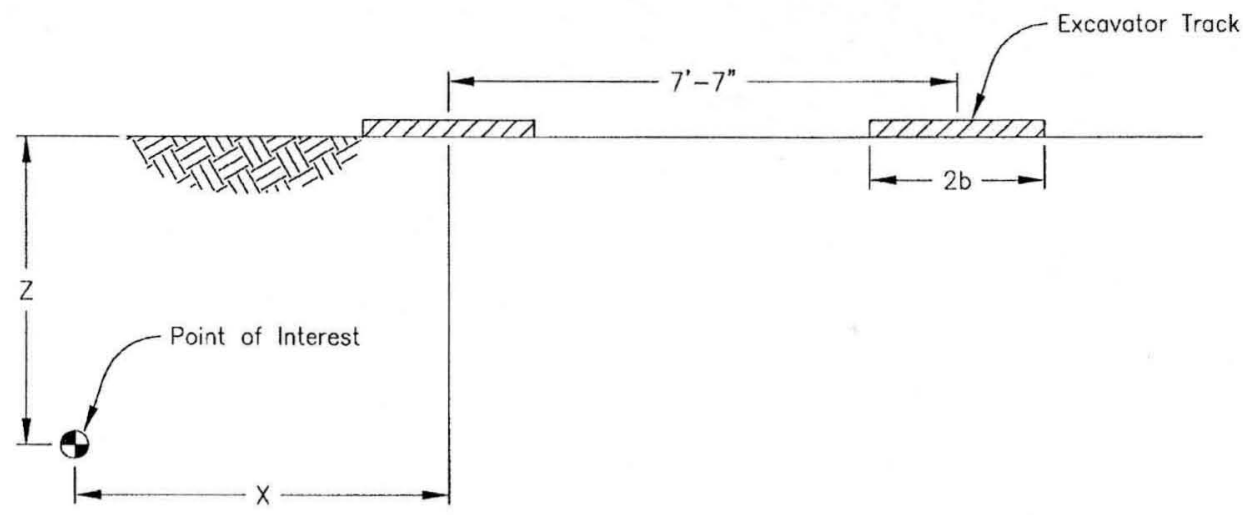

Excavator Track Configuration

Plot the lateral soil pressure for depth ranging from $0-16$ feet and track offsets from $5-20$ feet.

$\mathrm{z}:=0 \mathrm{ft}, .1 \mathrm{ft} . .16 \mathrm{ft} \quad \mathrm{x}:=5 \mathrm{ft}, 10 \mathrm{ft} . .20 \mathrm{ft}$

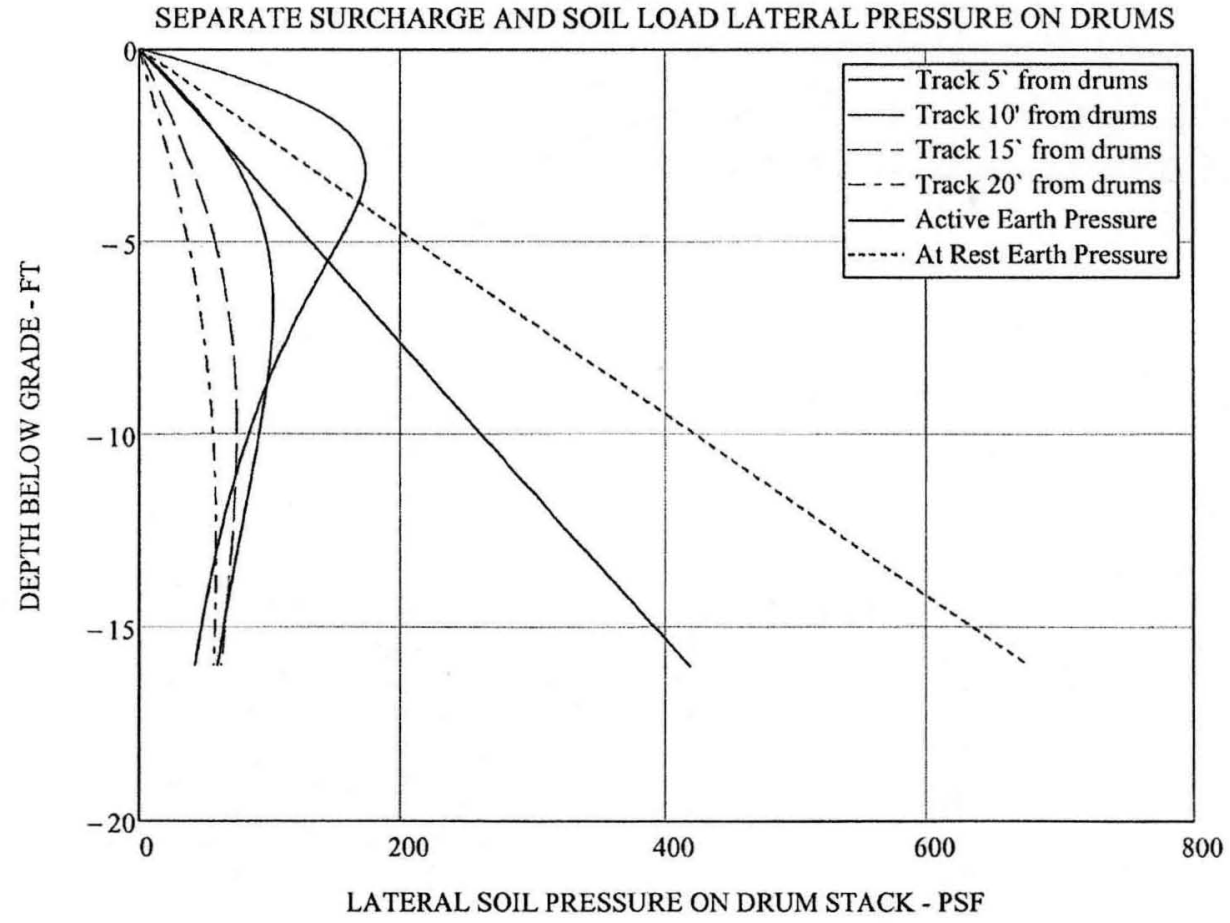


Fluor Hanford, Inc.

Client: Fluor Hanford Subject: Slope Stability Analysis for Exavation Work At CWC Trench Location: CWC 200W

\section{ENGINEERING ANALYSIS}

Calc. No.:122633-C-004

Revision: 0

Page No.: 4 of 9

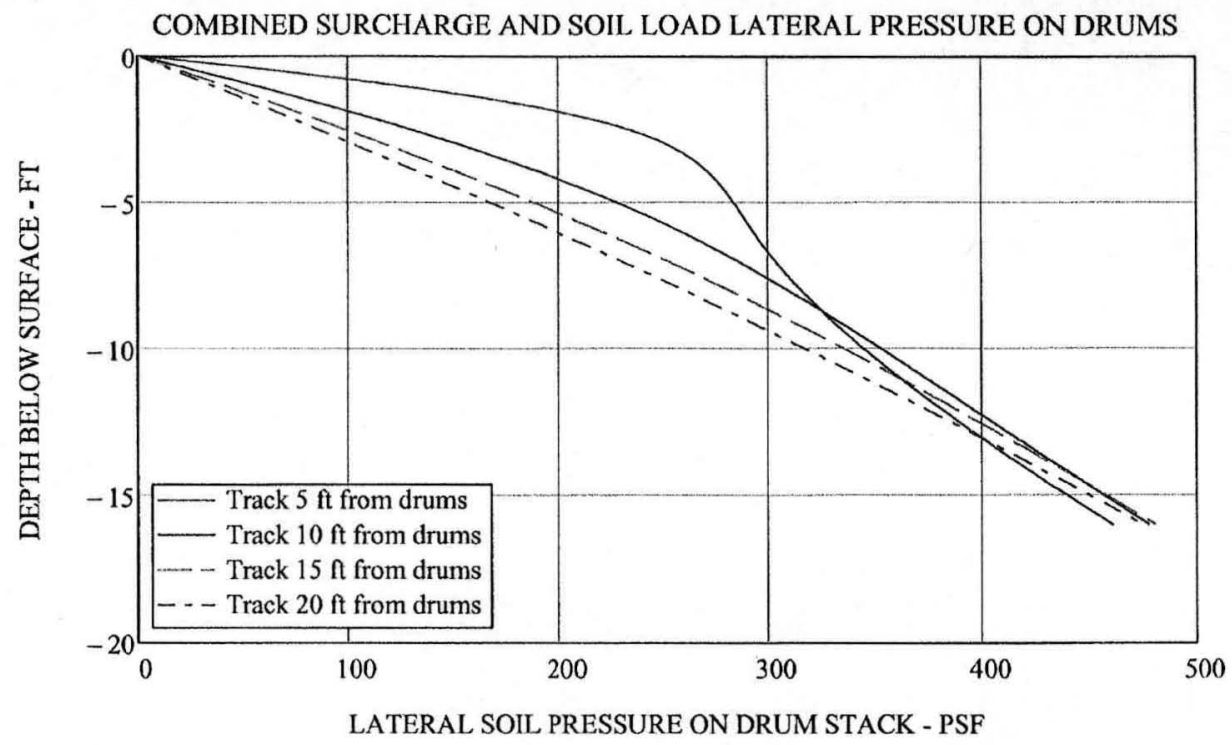

No information could be found on drum collaps from external pressure so a lower limit pressure was determined $b$ assuming the stiffening rings on the drum provided no increase in support against external pressure.

Assume 18 gage carbon steel drum:

Drum shell thickness, $t:=0.0478$ in Drum diameter, $D:=23.5$ in Drum height, $L_{d}:=34.5$ in

Youngs modulus for the steel, $\mathrm{E}:=29000 \mathrm{ksi}$ Poissons ratio for the steel, $v:=0.3$

Drum radius, $r:=\frac{D}{2}=11.75 \cdot$ in $\quad 4.9 \cdot r \cdot \sqrt{\frac{r}{t}}=75.224 \mathrm{ft} \quad$ Use short tube formula

$\mathrm{q}^{\prime}:=0.807 \cdot \frac{\mathrm{E} \cdot \mathrm{t}^{2}}{\mathrm{~L}_{\mathrm{d}} \cdot \mathrm{r}} \cdot \sqrt[4]{\left(\frac{1}{1-v^{2}}\right)^{3} \cdot \frac{\mathrm{t}^{2}}{\mathrm{r}^{2}}}=1.3 \times 10^{3} \cdot \mathrm{psf}$

Roark Table 15.2 - Case 19

$60<\left(\frac{L_{d}}{r}\right)^{2} \cdot\left(\frac{r}{t}\right)<2.5 \cdot\left(\frac{r}{t}\right)^{2}=1 \quad q^{\prime \prime}:=\frac{0.92 E}{\left(\frac{L_{d}}{r}\right) \cdot\left(\frac{r}{t}\right)^{2.5}}=1.381 \times 10^{3} \cdot p s f$

Roark Table 15.2 - Case 20 


\section{Fluor Hanford, Inc.}

Client: Fluor Hanford Subject: Slope Stability Analysis for Exavation Work At CWC Trench Location: CWC $200 \mathrm{~W}$
ENGINEERING ANALYSIS
Calc. No.:122633-C-004

Revision: 0

Page No.: 5 of 9

T.O./Job No.: 65400811.122633

Originated by: D.S. Messinger, P.E. A.Menger Date: $/ 1-23-07$

Checked by: David S. McShane, P.EDS h C due Date: $11.23-07$

Factors of Safety for Drum Collapse using Active Earth Pressure (Recommended)

$\mathrm{FS}_{\mathrm{q}^{\prime}}:=\frac{\mathrm{q}^{\prime}}{\left(\sigma_{\mathrm{x}}(15 \mathrm{ft}, 16 \mathrm{ft})+\sigma_{\mathrm{x}}(22.6 \mathrm{ft}, 16 \mathrm{ft})+\gamma \cdot 16 \mathrm{ft} \cdot \mathrm{K}_{\mathrm{A}}\right)}=2.706$
$\mathrm{FS}_{\mathrm{q}^{\prime \prime}}:=\frac{\mathrm{q}^{\prime \prime}}{\left(\sigma_{\mathrm{x}}(15 \mathrm{ft}, 16 \mathrm{ft})+\sigma_{\mathrm{x}}(22.6 \mathrm{ft}, 16 \mathrm{ft})+\gamma \cdot 16 \mathrm{ft} \cdot \mathrm{K}_{\mathrm{A}}\right)}=2.875$

Factors of Safety for Drum Collapse using At Rest Earth Pressure

$\mathrm{FS}_{\mathrm{q}^{\prime}}:=\frac{\mathrm{q}^{\prime}}{\left(\sigma_{\mathrm{x}}(15 \mathrm{ft}, 16 \mathrm{ft})+\sigma_{\mathrm{x}}(22.6 \mathrm{ft}, 16 \mathrm{ft})+\gamma \cdot 16 \mathrm{ft} \cdot \mathrm{K}_{0}\right)}=1.761$
$\mathrm{FS}_{\mathrm{q}^{\prime \prime}}:=\frac{\mathrm{q}^{\prime \prime}}{\left(\sigma_{\mathrm{x}}(15 \mathrm{ft}, 16 \mathrm{ft})+\sigma_{\mathrm{x}}(22.6 \mathrm{ft}, 16 \mathrm{ft})+\gamma \cdot 16 \mathrm{ft} \cdot \mathrm{K}_{0}\right)}=1.871$

Following are the slope stability analysis by STB2006.

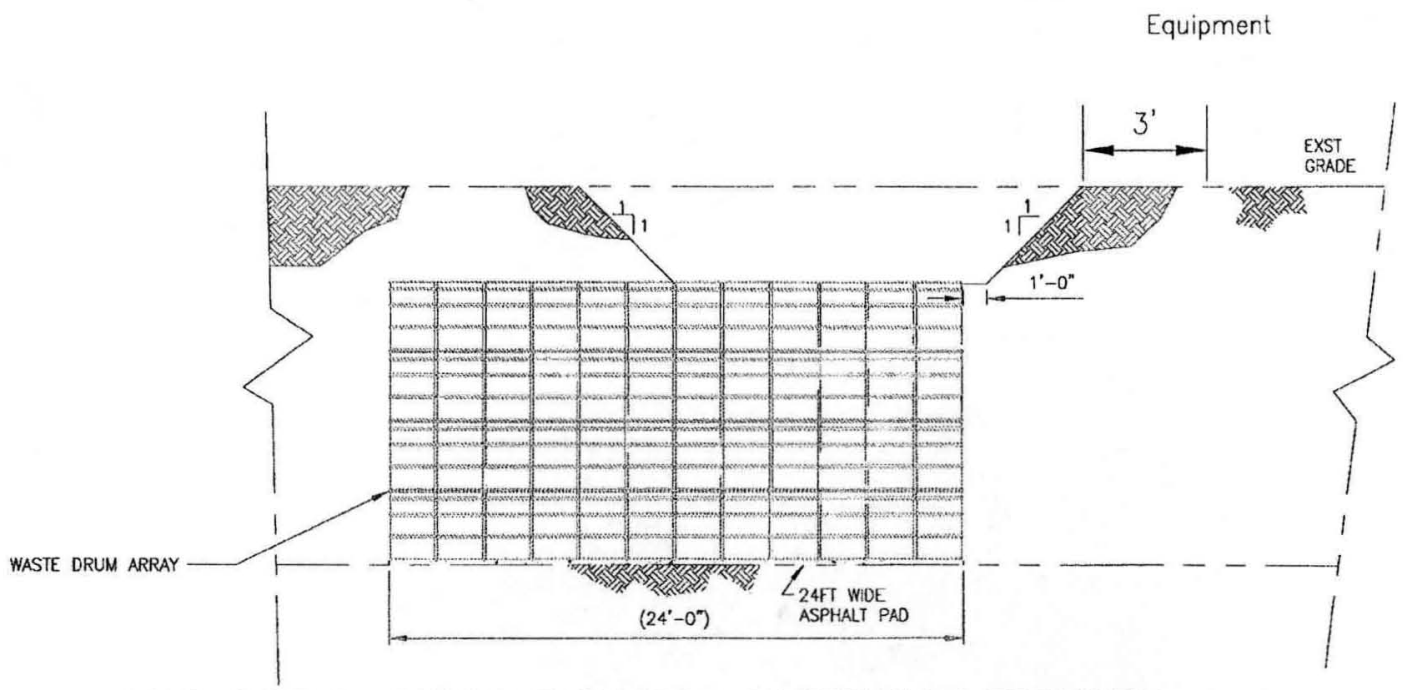

LOAD CASE 2 DURING EXCAVATION OF TRENCH OVERBURDEN 
Fluor Hanford, Inc.

Client: Fluor Hanford Subject: Slope Stability Analysis for Exavation Work At CWC Trench Location: CWC $200 \mathrm{~W}$
ENGINEERING

ANALYSIS
Calc. No.:122633-C-004

Revision: 0

Page No.: 6 of 9

T.0./Job No.: 65400811.122633

Originated by: D.S. Messinger, P.E Q. \&.1123.07 Checked by: David S. McShane, P.E.d) .SMc Shue Date: 11.23 .07
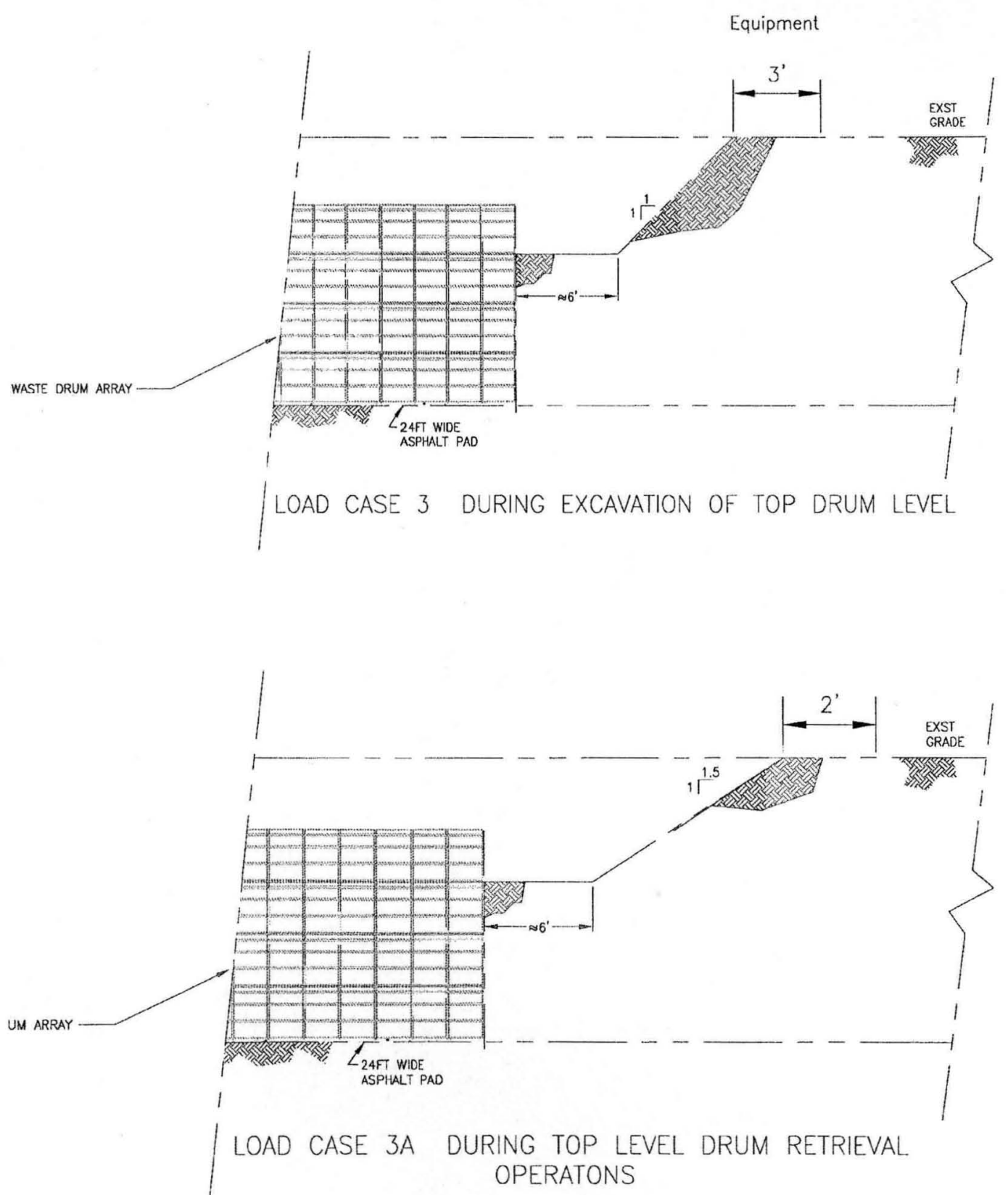
Fluor Hanford, Inc.

Client: Fluor Hanford Subject: Slope Stability Analysis for Exavation Work At CWC Trench Location: CWC 200W
ENGINEERING ANALYSIS
Calc. No.:122633-C-004

Revision: 0

Page No.: 7 of 9

T.O./Job No.: 65400811.122633

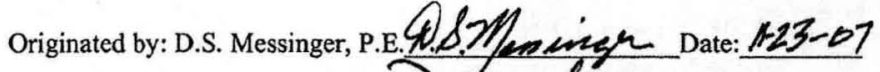
Checked by: David S. McShane, P.E.DSMCSlue Date: $11,23.07$

Equipment
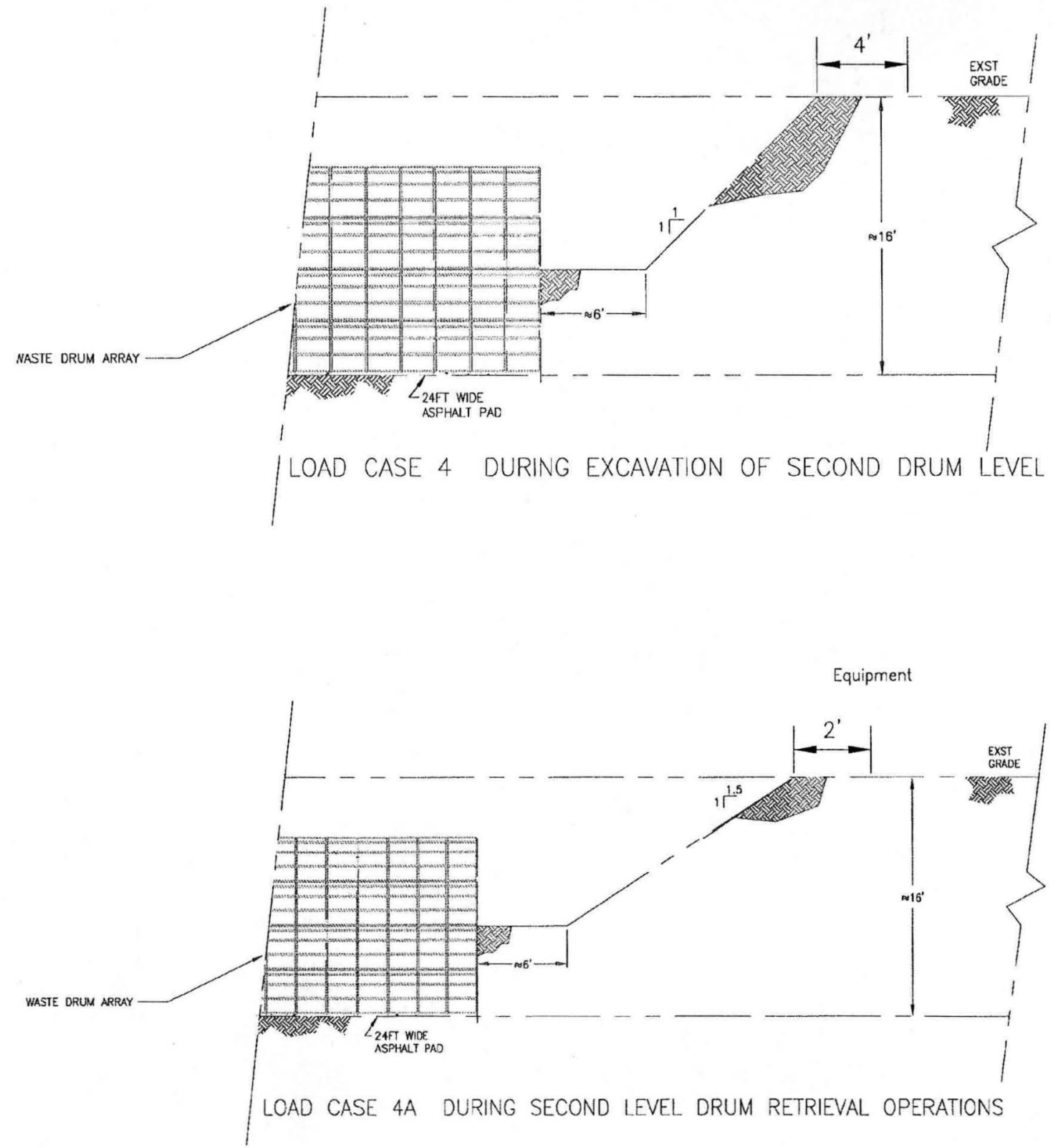
Fluor Hanford, Inc.

Client: Fluor Hanford Subject: Slope Stability Analysis for Exavation Work At CWC Trench Location: CWC 200W
ENGINEERING

ANALYSIS
Calc. No.:122633-C-004

Revision: 0

Page No.: 8 of 9

T.O./Job No.: 65400811.122633

Originated by: D.S. Messinger, P.E. D. \&.MPeninger Date: $11-23.07$ Checked by: David S. McShane, P.E. DS. MC he Date: $11.23-07$

Equipment
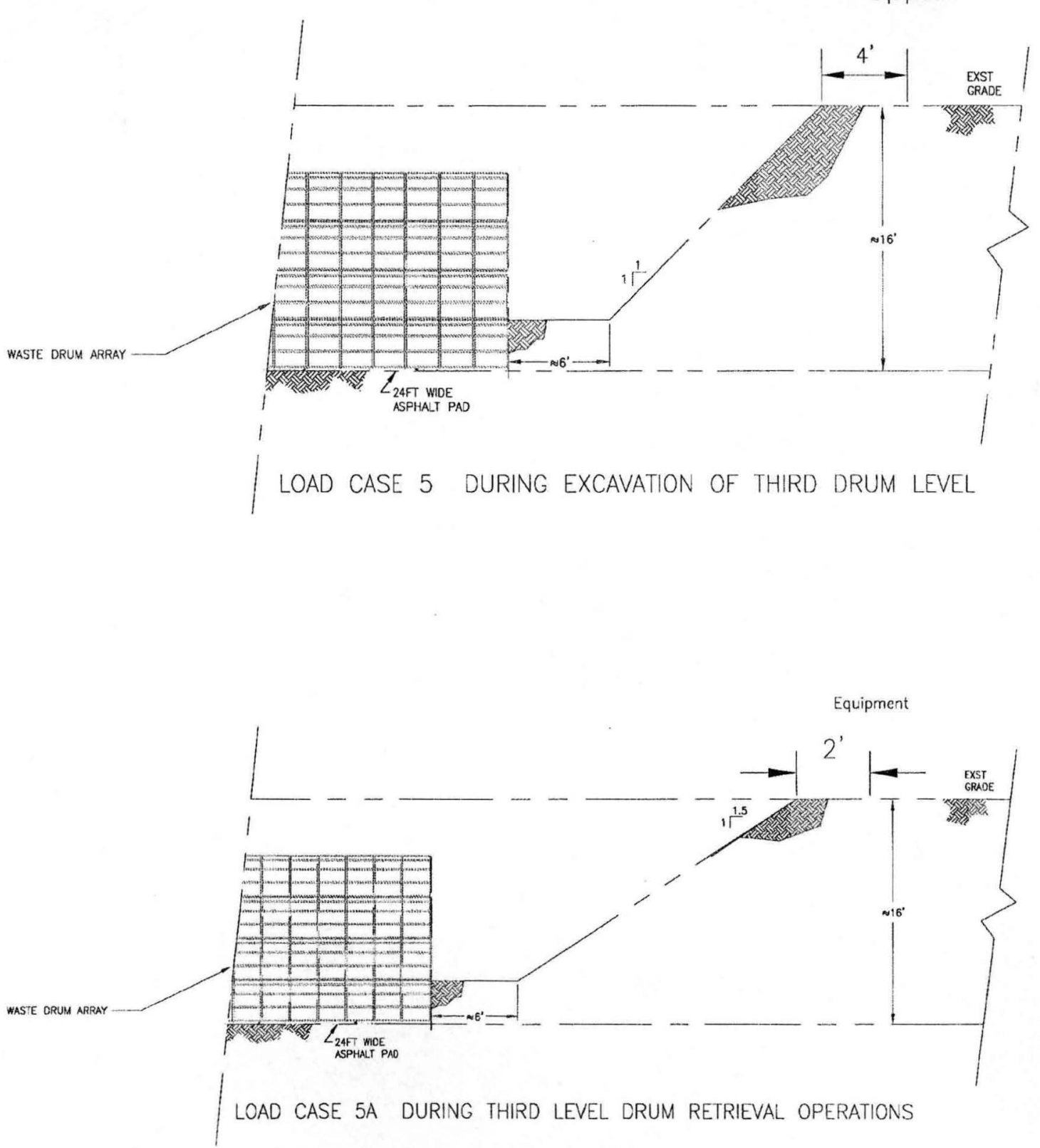
Fluor Hanford, Inc.

Client: Fluor Hanford

Subject: Slope Stability Analysis for

Exavation Work At CWC Trench

Location: CWC 200W
ENGINEERING

ANALYSIS
Calc. No.:122633-C-004

Revision: 0

Page No.: 9 of 9

Originated by: D.S. Messinger, P.E. $9.1 .71 / 23-07$ Checked by: David S. McShane, P.E. I) SMC Date: $1-23-07$

Equipment
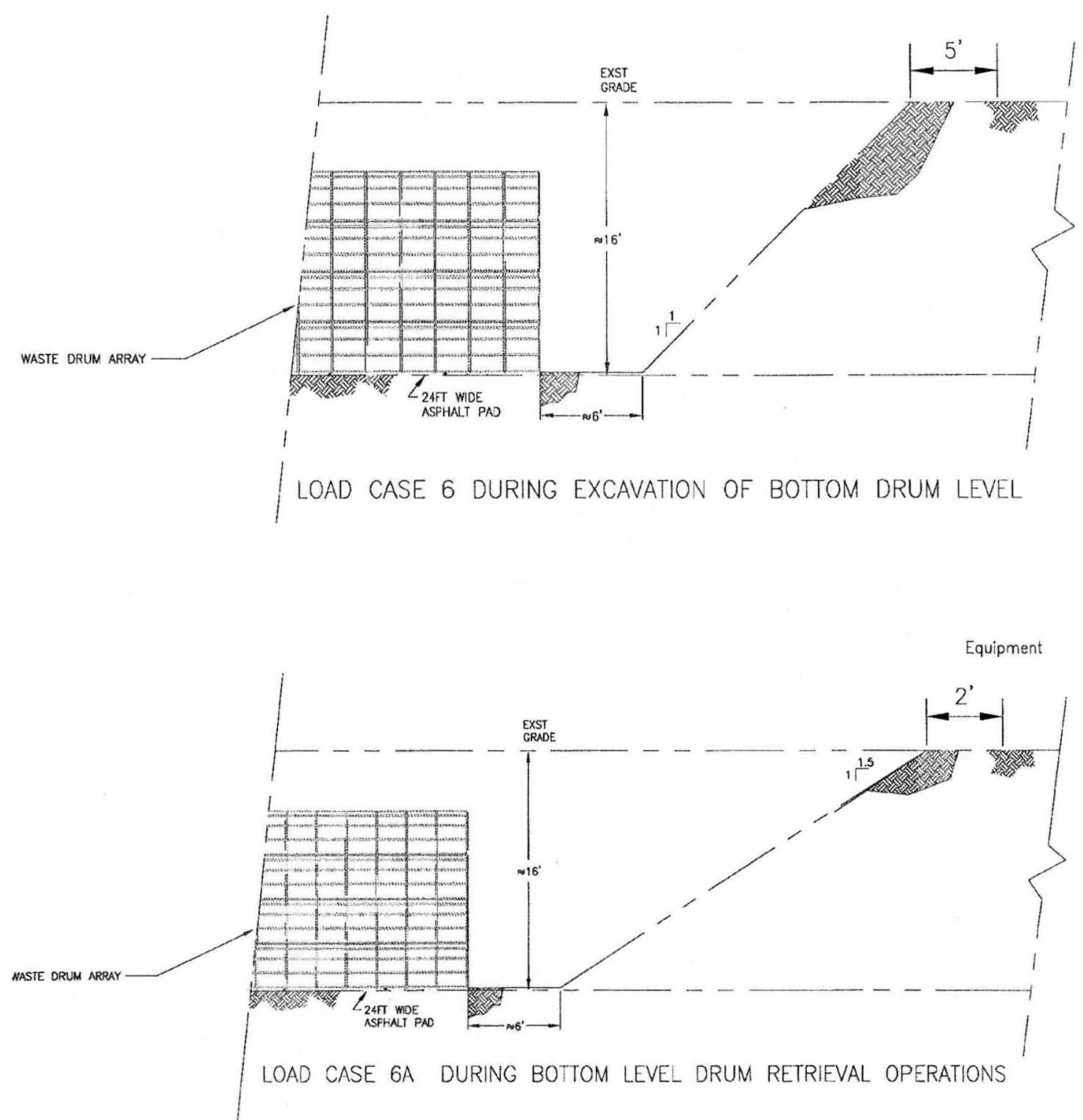
APPENDIX A

CALC. NO. 122633-C-004

Appendix Page 1 of 43

APPENDIX A

(STB2006 SOLUTIONS) 


\section{ENGINEERING COMPUTER PROGRAM APPROVED FOR USE}

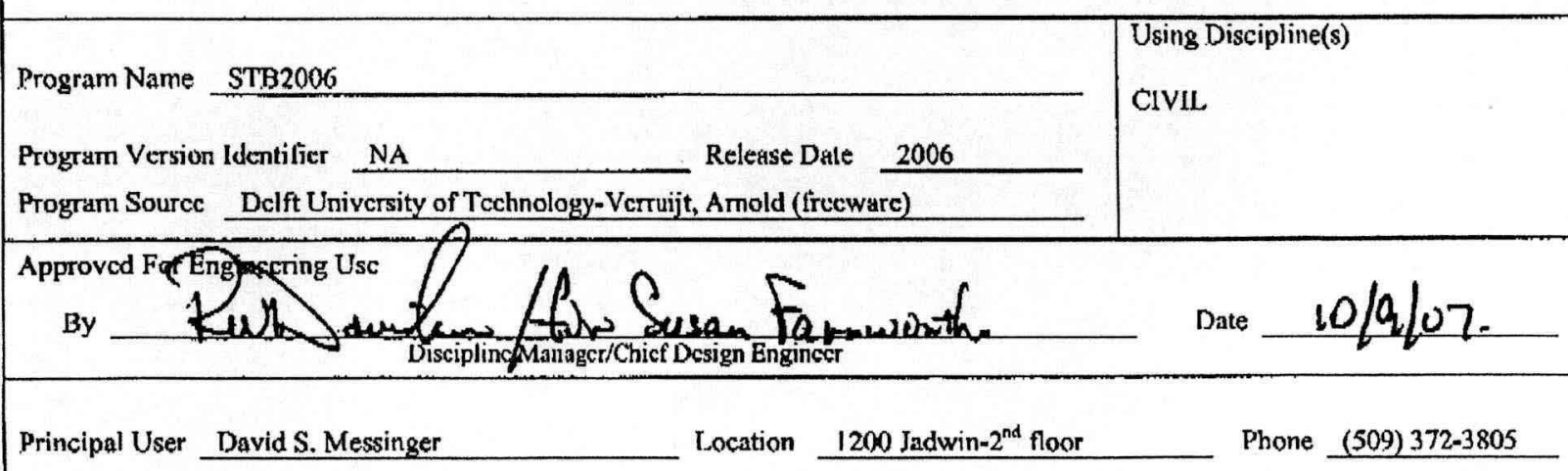

Program Abstract

STB2006 is a revised version of the approved program STB2004. There is no noticable difference in the "look and feel" of the two programs. Both SIB2006 and STB2004 have a tendency to lock up or freeze if certain improper graphical inputs are made to the problem, such as placing the center of the failure circle in a position that can not present a rational solution to the problem. Verification of the current version is based on re-running the same set of problems used in the verification and validation of S'I32004. C.opies of the hand solved problems from the S'ri32004 V\&V package are included as a part of this V\&V package.

SIB is a program for the analysis of stability of a slope, using Bishop's simplified method, with some modifications introduced at GeoDelft and the Delft University. In this manual the various parts of the program are described, together with the basic methods and the definitions of the parameters. The manual catn also be printed, by clicking the I'IIN'T button of the screen 'Manual'. The program can bc downloaded free of charge from the intemest, from the page $<$ http://geon.verruijt.net:. Updated versions of the program will bc announccd on this page. The program may be used, copied and distributed without limitation, provided that it is not modified in any way. No responsibility is accepted by the author or the distributor of the program for any errors or for losses or damages incurred by using the program.

In Bishop's method the safety factor of a slope is determined by comparing the moment of the weight of a soil wedge about the center of a slip circle, with the resisting moment provided by the shear stresses along the slip surface. The two moments are calculated by subdividing the sliding wedge into a large number of vertical slices. It is assumed that on the vertical side planes ol the slices only horizontal (normal) stresses are acting, and no shcar stresses. The lirst basic equation is Coulomb's cquation for the shear stress along the lower part of a slice, $t=\left[c+(s-p)^{*} \tan (p h i)\right] / F$, here $t$ is the shear stress, $c$ is the cohcsion, $s$ is the total stress normal to the sliding planc, $p$ is the porc water pressurc, phi is the angle of internal fiction, and $F$ is the safety factor. The sccond busic cquation is the cquation of verticul equilibrium of a slice, which gives $W^{*} h=s+t^{*} \tan (a l p h a)$, where $W$ is the (average) unit weight of the slice, $h$ is its height, and alpha is the slope of the slip surface at the slice considered.

Equilibrium of noments with respect to the center of the circle lcads to a formula from which the safety factor can bc calculatcd, iteratively. The program STB2006 also contains the threc refincments of Bishop's method.

1- The first refinement is that care is taken that the dircetion of the shear stress along the slip surface is always opposing the sliding mechanism. This is achicved by cutting off the valuc of alpha at a minimum value of phi/2-pi/4. This refinement is duc to A. W. Koppejan of GeoDelft.

2- The second refinement is that the shearing resistance is reduccd if the cocfficicnt of ncutral horizontal strcss is so small that slip would occur along a plane perpendicular to the slip surface, combined with a local rotation, in agreement with a double sliding model, as suggested by $\mathrm{G}$, de Josselin de Jong. This refinement is effective only if the coefficient of neutral horizontal stress (Ko) is smaller than 1.

3 - The third refinement is that it is possible to introduce a horizontal body force, away from the slope. This may be used to simulate the stability of the slope during an earthquake. The horizontal forces acting on the slices increases the moment of the weight of the slices with respect to the center of the slip circle, thus reducing the stability factor.

(See Appendix Sheets for linitations, verification problens and hard copy of the manual.) 
APPENDIX A

CALC. NO. 122633-C-004

\section{ENGINEERING COMPUTER PROGRAM APPROVED FOR USE}

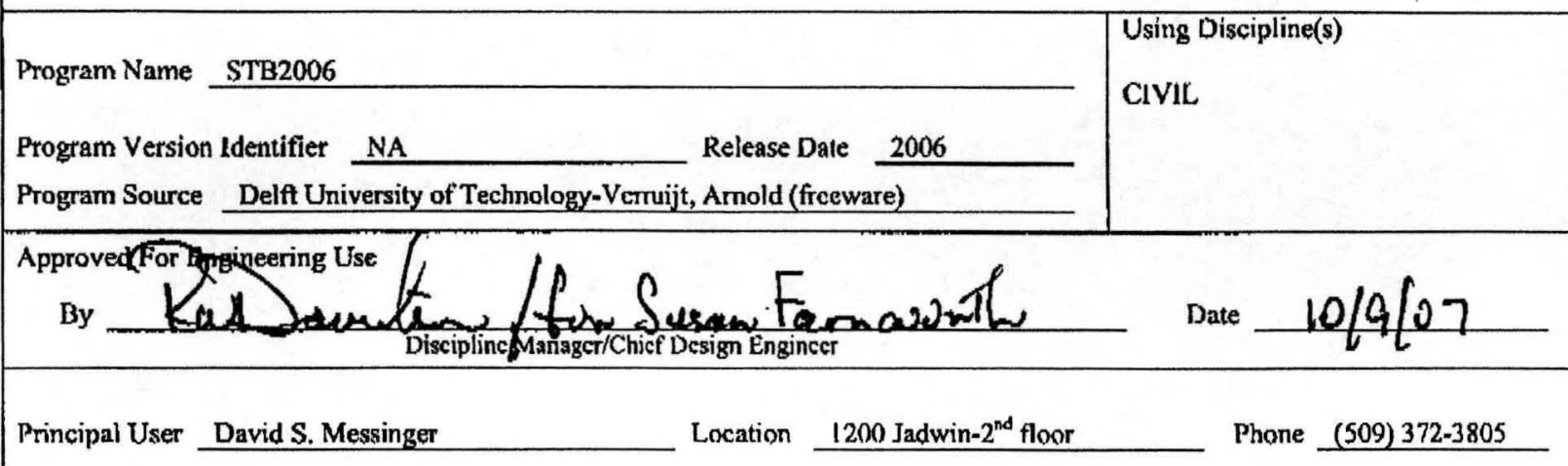

Program Abstract

(Continued from page 1)

L,imitations: The program limitations may be found within the programs help files and embedded electronic manual.

Verification: Three verification test problems are supplied with the software. These problems are listed as test 1 through test 3 and demonstrate the various capabilities of the program, In addition, the FGG verifier (David S. Messinger, P.E.) produced five additional test problems based on publislred slope stability problems and answers. These additional verification problems were worked by hand, during the verification of STB2004 compared to the published answers and compared to the program generated output for S'T(32006. The program generated acceptable results in all cases. The verification problems are attached.

STB2006 is authorized for use only after verification by each user on stand-alone personal computers. Authorization is granted only on the specific petsonal computers on which the verification have been run. Verification must be documented on the ACCEPTANCE TEST RECORD form and submitted to the FGG STB2006 Principal User.

STB2006 is authorized for use by professional engineers who possess an understanding of soil mechanics. Users must verify the accuracy and applicability of the results. 
STB2006 - Slope Stability

Copyright $@ 2006$ by A. Verruijt
APPENDIX A

CALC. NO. 122633-C-004
Appendix Page 4 of 43

Page 1

David S. Messinger, P.E., Load Case 2

General Data

Licensed User

File Name

Problem Name

Number of Slices

Number of Nodes

0.000000

Number of Soil Polygons : 3

\section{Definition Figure}

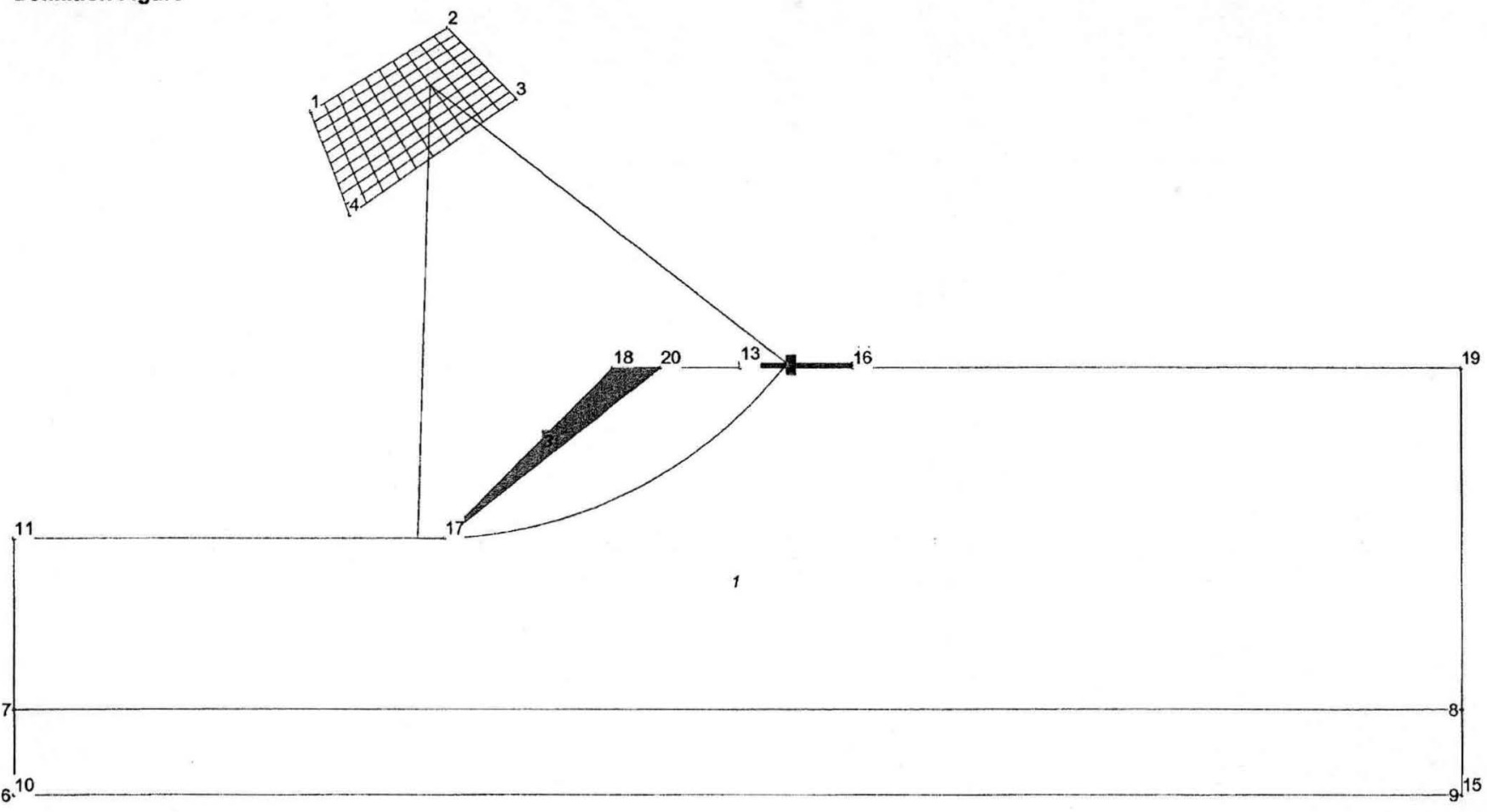

Input Data

Coordinates of Nodes

$\begin{array}{ccc}\text { Node } & x & y \\ 1 & 6.828 & 16.020 \\ 2 & 10.092 & 17.985 \\ 3 & 11.724 & 16.320 \\ 4 & 7.761 & 13.589 \\ 5 & 10.000 & 6.000 \\ 6 & 0.000 & 0.000 \\ 7 & 0.000 & 2.000 \\ 8 & 33.974 & 2.000 \\ 9 & 33.974 & 0.000 \\ 10 & 0.000 & 0.000 \\ 11 & 0.000 & 6.000 \\ 12 & 16.986 & 10.000 \\ 13 & 16.986 & 10.100 \\ 14 & 19.611 & 10.100 \\ 15 & 33.974 & 0.000 \\ 16 & 19.611 & 10.000 \\ 17 & 10.000 & 6.000 \\ 18 & 14.000 & 10.000 \\ 19 & 33.974 & 10.000 \\ 20 & 15.120 & 10.000\end{array}$

Structure of Polygons

Window of centers of slip circles

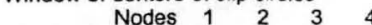

Fixed point of all slip circles

Water Pode

$\begin{array}{cccccc}\text { Nodes } & 6 & 7 & 8 & 9\end{array}$

$\begin{array}{lllllllll}1: & \text { Nodes } & 10 & 11 & 17 & 20 & 12 & 19 & 15 \\ 2: & \text { Nodes } & 12 & 13 & 14 & 16 & & & \end{array}$

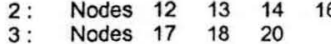


STB2006 - Slope Stability

David S. Messinger, P.E., Load Case 2

Properties of Soils

$\begin{array}{ccccccccc}\text { Soil } & \begin{array}{c}W d \\ \mathrm{kN} / \mathrm{m}^{3}\end{array} & \begin{array}{c}W \mathrm{Ws} \\ \mathbf{k N} / \mathrm{m}^{3}\end{array} & \begin{array}{c}\mathrm{Ko} \\ -\end{array} & \begin{array}{c}\mathrm{c} \\ \mathrm{kN} / \mathrm{m}^{2}\end{array} & \begin{array}{c}\text { phi } \\ \text { degrees }\end{array} & \mathrm{P} / \mathrm{F} & \begin{array}{c}\mathrm{p}=0 \\ \mathrm{~m}\end{array} & \begin{array}{c}\text { cap } \\ \mathrm{m}\end{array} \\ 1 & 110.000 & 110.000 & 1.000 & 0.000 & 38.000 & \mathrm{P} & & 0.000 \\ 2 & 12571.430 & 12571.430 & 1.000 & 0.000 & 0.000 & \mathrm{P} & & 0.000 \\ 3 & 110.000 & 110.000 & 1.000 & 0.000 & 38.000 & \mathrm{P} & & 0.000\end{array}$

\section{Output Data}

\section{Safety Factors}

$\begin{array}{lllllllllll}1.241 & 1.247 & \mathbf{1 . 2 5 5} & 1.262 & 1.274 & 1.283 & 1.318 & 1.347 & \mathbf{1 . 3 7 9} & 1.412 & 1.447 \\ 1.202 & 1.208 & \mathbf{1 . 2 1 3} & 1.218 & 1.223 & 1.234 & 1.240 & 1.247 & 1.254 & 1.266 & 1.274 \\ 1.173 & 1.176 & \mathbf{1 . 1 7 9} & 1.183 & 1.187 & 1.190 & 1.199 & 1.202 & 1.207 & 1.212 & 1.217 \\ 1.169 & 1.168 & \mathbf{1 . 1 6 9} & 1.169 & 1.165 & 1.167 & 1.171 & 1.172 & 1.180 & 1.181 & 1.184 \\ 1.194 & \mathbf{1 . 1 9 0} & \mathbf{1 . 1 8 8} & 1.185 & 1.184 & 1.184 & 1.186 & 1.187 & 1.187 & 1.188 & 1.190 \\ 1.319 & \mathbf{1 . 3 1 5} & \mathbf{1 . 3 0 5} & \mathbf{1 . 2 8 9} & 1.285 & 1.282 & 1.282 & 1.284 & 1.287 & 1.287 & 1.294 \\ 1.483 & \mathbf{1 . 4 7 2} & \mathbf{1 . 4 6 3} & \mathbf{1 . 4 5 6} & 1.451 & 1.448 & 1.447 & 1.447 & 1.449 & 1.453 & 1.458 \\ 1.468 & \mathbf{1 . 4 4 8} & \mathbf{1 . 4 2 9} & \mathbf{1 . 4 1 3} & 1.398 & 1.385 & 1.373 & 1.364 & 1.356 & 1.349 & 1.345 \\ 1.495 & \mathbf{1 . 4 6 7} & 1.439 & 1.413 & 1.389 & 1.366 & 1.344 & 1.324 & 1.305 & 1.288 & 1.272 \\ 1.581 & 1.545 & 1.511 & 1.477 & 1.444 & 1.413 & 1.382 & 1.352 & 1.324 & 1.296 & 1.270 \\ 1.746 & \mathbf{1 . 7 0 8} & 1.670 & 1.633 & 1.596 & 1.560 & 1.525 & 1.491 & 1.457 & 1.424 & 1.392\end{array}$

Critical slip circle

Center: $x=9.682, y=16.638$, Radius: $10.642, F=1.165$

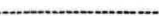

APPENDIX A

CALC. NO. 122633-C-004 
David S. Messinger, P.E., Load Case 2A

General Data

$$
\begin{array}{ll}
\text { Licensed User } & : \text { David S. Messinger, P.E. } \\
\text { File Name } & : \text { CWC02A.stb } \\
\text { Problem Name } & : \text { Load Case 2A } \\
\text { Number of Slices } & : 1000 \\
\text { Relative Horizontal Force: } 0.000000 & : 20 \\
\text { Number of Nodes } & : 20 \\
\text { Number of Soil Polygons }: 3
\end{array}
$$

Figure with critical slip circle

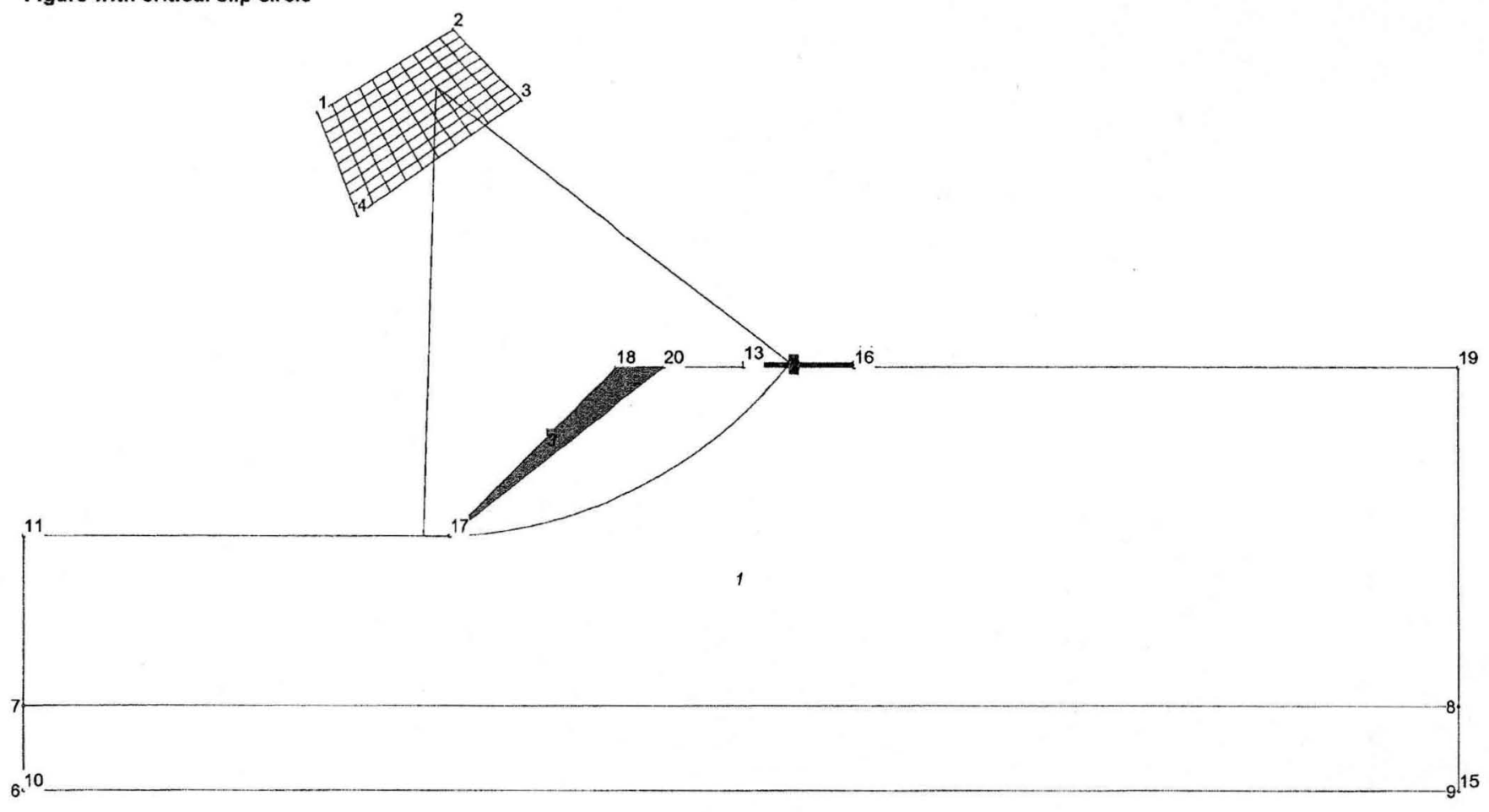

$F=1.165$

\section{Input Data}

\section{Coordinates of Nodes}

$\begin{array}{ccc}\text { Node } & x & y \\ 1 & 6.828 & 16.020 \\ 2 & 10.092 & 17.985 \\ 3 & 11.724 & 16.320 \\ 4 & 7.761 & 13.589 \\ 5 & 10.000 & 6.000 \\ 6 & 0.000 & 0.000 \\ 7 & 0.000 & 2.000 \\ 8 & 33.974 & 2.000 \\ 9 & 33.974 & 0.000 \\ 10 & 0.000 & 0.000 \\ 11 & 0.000 & 6.000 \\ 12 & 16.986 & 10.000 \\ 13 & 16.986 & 10.100 \\ 14 & 19.611 & 10.100 \\ 15 & 33.974 & 0.000 \\ 16 & 19.611 & 10.000 \\ 17 & 10.000 & 6.000 \\ 18 & 14.000 & 10.000 \\ 19 & 33.974 & 10.000 \\ 20 & 15.120 & 10.000\end{array}$


STB2006 - Slope Stability

David S. Messinger, P.E., Load Case 2A

\section{Structure of Polygons}

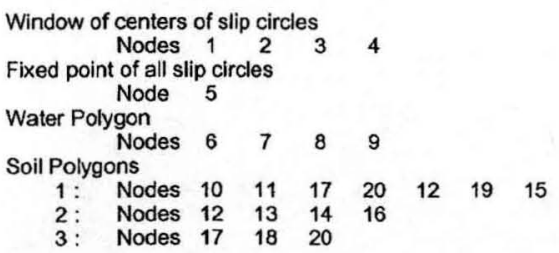

Properties of Solls

$\begin{array}{ccccccccc}\text { Soil } & \begin{array}{c}W d \\ \mathrm{kN} / \mathrm{m}^{3}\end{array} & \begin{array}{c}\mathrm{Ws} \\ \mathrm{kN} / \mathrm{m}^{3}\end{array} & \begin{array}{c}\mathrm{Ko} \\ \end{array} & \begin{array}{c}\mathrm{c} \\ \mathrm{kN} / \mathrm{m}^{2}\end{array} & \begin{array}{c}\text { phi } \\ \text { degrees }\end{array} & \begin{array}{c}\mathrm{P} / \mathrm{F} \\ \mathrm{p}=0\end{array} & \begin{array}{c}\text { cap } \\ \mathrm{m}\end{array} \\ 1 & 110.000 & 110.000 & 1.000 & 0.000 & 38.000 & \mathrm{P} & & 0.000 \\ 2 & 12571.430 & 12571.430 & 1.000 & 0.000 & 0.000 & \mathrm{P} & & 0.000 \\ 3 & 110.000 & 110.000 & 1.000 & 0.000 & 38.000 & \mathrm{P} & & 0.000\end{array}$

\section{Output Data}

\section{Safety Factors}

\begin{tabular}{|c|c|c|c|c|c|c|c|c|c|c|}
\hline 1.241 & 1.247 & 1.255 & 1.262 & 1.274 & 1.283 & 1.318 & 1.347 & 1.379 & 1.412 & 1.446 \\
\hline 1.202 & 1.208 & 1.213 & 1.218 & 1.223 & 1.233 & 1.240 & 1.247 & 1.254 & 1.266 & 1.274 \\
\hline 1.173 & 1.176 & 1.179 & 1.183 & 1.187 & 1.190 & 1.199 & 1.203 & 1.207 & 1.212 & 1.217 \\
\hline 1.169 & 1.168 & 1.169 & 1.169 & 1.165 & 1.167 & 1.171 & 1.172 & 1.180 & 1.181 & 1.184 \\
\hline 1.194 & 1.190 & 1.188 & 1.185 & 1.184 & 1.184 & 1.186 & 1.187 & 1.187 & 1.188 & 1.190 \\
\hline 1.319 & 1.315 & 1.305 & 1.289 & 1.285 & 1.282 & 1.282 & 1.284 & 1.288 & 1.287 & 1.294 \\
\hline 1.483 & 1.472 & 1.463 & 1.456 & 1.451 & 1.448 & 1.447 & 1.447 & 1.449 & 1.453 & 1.458 \\
\hline 1.468 & 1.448 & 1.429 & 1.413 & 1.398 & 1.385 & 1.373 & 1.364 & 1.356 & 1.350 & 1.345 \\
\hline 1.495 & 1.467 & 1.439 & 1.413 & 1.389 & 1.366 & 1.344 & 1.324 & 1.305 & 1.288 & 1.272 \\
\hline 1.58 & 1.545 & 1.511 & 1.477 & 1.444 & 1.413 & 1.382 & 1.352 & 1.323 & 1.296 & 1.270 \\
\hline .746 & 1.708 & 1.670 & 1.633 & 1.596 & 1.560 & 1.525 & 1.491 & 1.457 & 1.424 & 1.392 \\
\hline
\end{tabular}

Critical slip circle

APPENDIX A

CALC. NO. 122633-C-004
Appendix Page 7 of 43

Page 2

Center: $x=9.682, y=16.638$, Radius: $10.642, F=1.165$ 
STB2006 - Slope Stability

APPENDIX A

CALC. NO. 122633-C-004
Appendix Page 8 of 43

Page 1

David S. Messinger, P.E., Load Case 2B

\section{General Data}

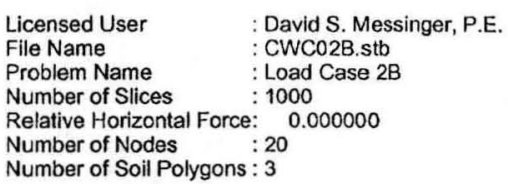

Number of Soil Polygons : 3

Figure with critical slip circle

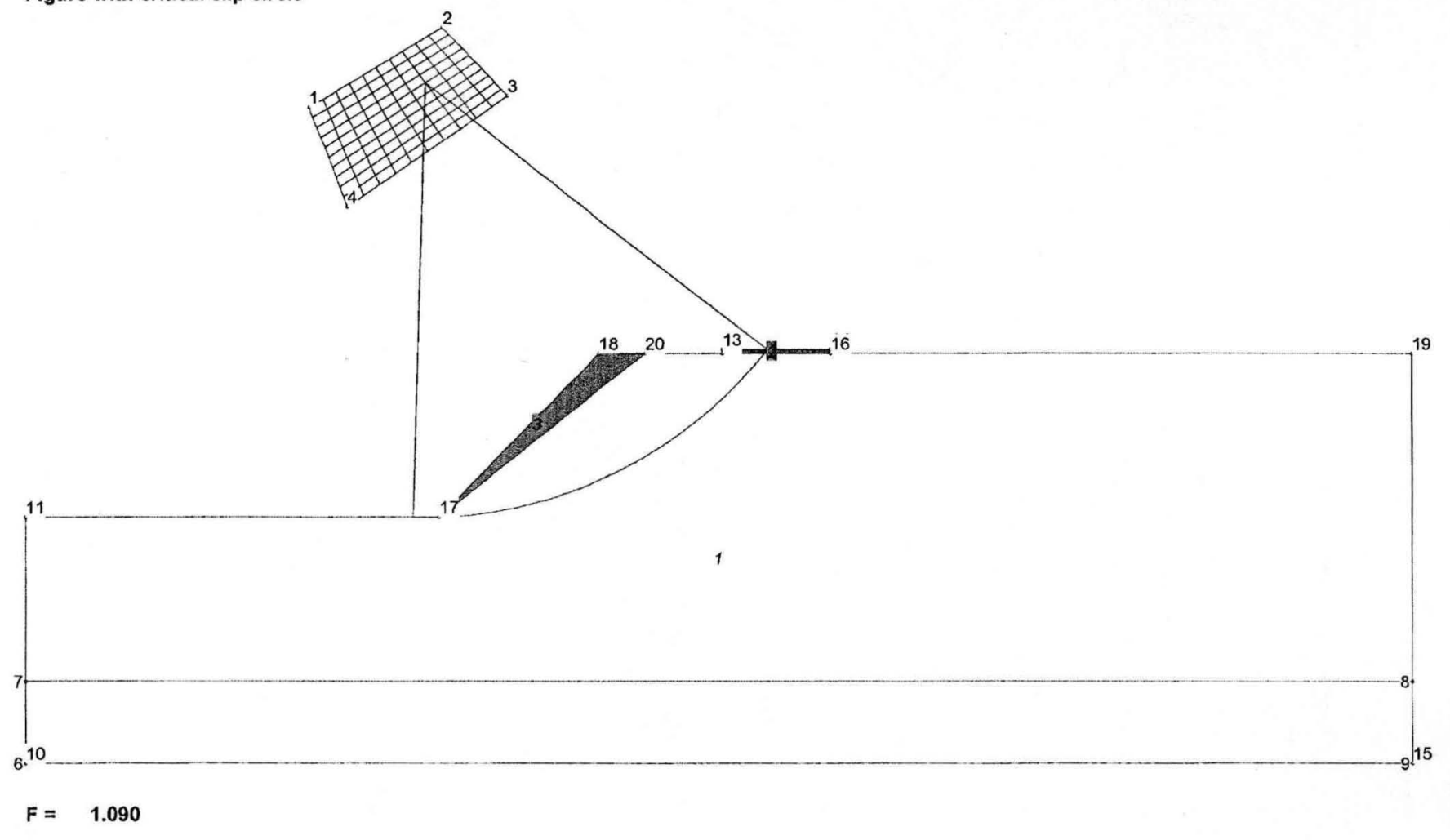

Input Data

Coordinates of Nodes

$\begin{array}{ccc}\text { Node } & \mathrm{x} & \mathrm{y} \\ 1 & 6.828 & 16.020 \\ 2 & 10.092 & 17.985 \\ 3 & 11.724 & 16.320 \\ 4 & 7.761 & 13.589 \\ 5 & 10.000 & 6.000 \\ 6 & 0.000 & 0.000 \\ 7 & 0.000 & 2.000 \\ 8 & 33.974 & 2.000 \\ 9 & 33.974 & 0.000 \\ 10 & 0.000 & 0.000 \\ 11 & 0.000 & 6.000 \\ 12 & 16.986 & 10.000 \\ 13 & 16.986 & 10.100 \\ 14 & 19.611 & 10.100 \\ 15 & 33.974 & 0.000 \\ 16 & 19.611 & 10.000 \\ 17 & 10.000 & 6.000 \\ 18 & 14.000 & 10.000 \\ 19 & 33.974 & 10.000 \\ 20 & 15.120 & 10.000\end{array}$


STB2006 - Slope Stability

David S. Messinger, P.E., Load Case 2B

\section{Structure of Polygons}

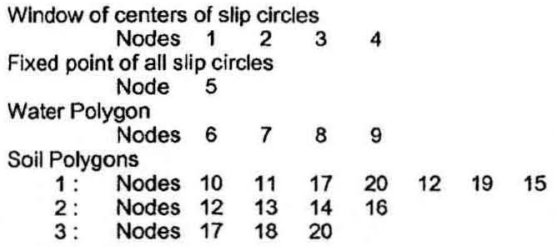

Propertles of Soils

\begin{tabular}{|c|c|c|c|c|c|c|c|c|}
\hline Soil & $\begin{array}{l}\mathrm{Wd} \\
\mathrm{kN} / \mathrm{m}^{3}\end{array}$ & $\begin{array}{l}\mathrm{Ws} \\
\mathrm{kN} / \mathrm{m}^{3}\end{array}$ & Ko & $\underset{\mathrm{kN} / \mathrm{m}^{2}}{\mathrm{c}}$ & $\begin{array}{c}\text { phi } \\
\text { degrees }\end{array}$ & P/F & $\begin{array}{l}p=0 \\
m\end{array}$ & $\begin{array}{c}\text { cap } \\
\mathrm{m}\end{array}$ \\
\hline 1 & 110.000 & 110.000 & 1.000 & 0.000 & 38.000 & $\mathrm{P}$ & & 0.000 \\
\hline 2 & 12571.430 & 12571.430 & 1.000 & 0.000 & 0.000 & $\mathrm{P}$ & & 0.000 \\
\hline 3 & 0.000 & 10.000 & 1.000 & 0.000 & 0.000 & P & & 0.000 \\
\hline
\end{tabular}

\section{Output Data}

\section{Safety Factors}

\begin{tabular}{|c|c|c|c|c|c|c|c|c|c|c|}
\hline 1.183 & 1.189 & 1.196 & 1.204 & 1.217 & 1.225 & 1.260 & 1.288 & 1.318 & 1.349 & 1.383 \\
\hline 1.140 & 1.146 & 1.151 & 1.156 & 1.161 & 1.172 & 1.178 & 1.185 & 1.192 & 1.205 & 1.213 \\
\hline 1.105 & 1.108 & 1.112 & 1.116 & 1.120 & 1.123 & 1.132 & 1.136 & 1.140 & 1.145 & 1.151 \\
\hline 1.094 & 1.093 & 1.094 & 1.095 & 1.090 & 1.092 & 1.096 & 1.097 & 1.106 & 1.107 & 1.109 \\
\hline 1.111 & 1.107 & 1.105 & 1.101 & 1.100 & 1.100 & 1.102 & 1.103 & 1.103 & 1.104 & 1.106 \\
\hline 1.239 & 1.232 & 1.221 & 1.200 & 1.195 & 1.191 & 1.190 & 1.191 & 1.194 & 1.193 & 1.199 \\
\hline 1.457 & 1.441 & 1.428 & 1.417 & 1.408 & 1.401 & 1.397 & 1.395 & 1.395 & 1.397 & 1.400 \\
\hline 1.481 & 1.454 & 1.429 & 1.407 & 1.387 & 1.369 & 1.354 & 1.340 & 1.329 & 1.320 & 1.314 \\
\hline 1.576 & 1.539 & 1.503 & 1.469 & 1.438 & 1.408 & 1.380 & 1.355 & 1.331 & 1.310 & 1.291 \\
\hline 1.782 & 1.738 & 1.695 & 1.653 & 1.613 & 1.575 & 1.538 & 1.503 & 1.469 & 1.438 & 1.408 \\
\hline 2.175 & 2.136 & 2.099 & 2.063 & 2.030 & 1.999 & 1.970 & 1.941 & 1.911 & 1.881 & 1.850 \\
\hline
\end{tabular}

Critical slip circle

Center: $x=9.682, y=16.638$, Radius: $10.642, F=1.090$
APPENDIX A
NO. $122633-\mathrm{C}-004$
Page 2 
STB2006 - Slope Stability

APPENDIX A

CALC. NO. 122633-C-004

David S. Messinger, Load Case 3

General Data
Licensed User $\quad$ : David S. Messinge
Problem Name
Number of Slices : Load Case 3
: 1000
Relative Horizontal
Number of Nodes : $: 20$

Figure with critical slip circle

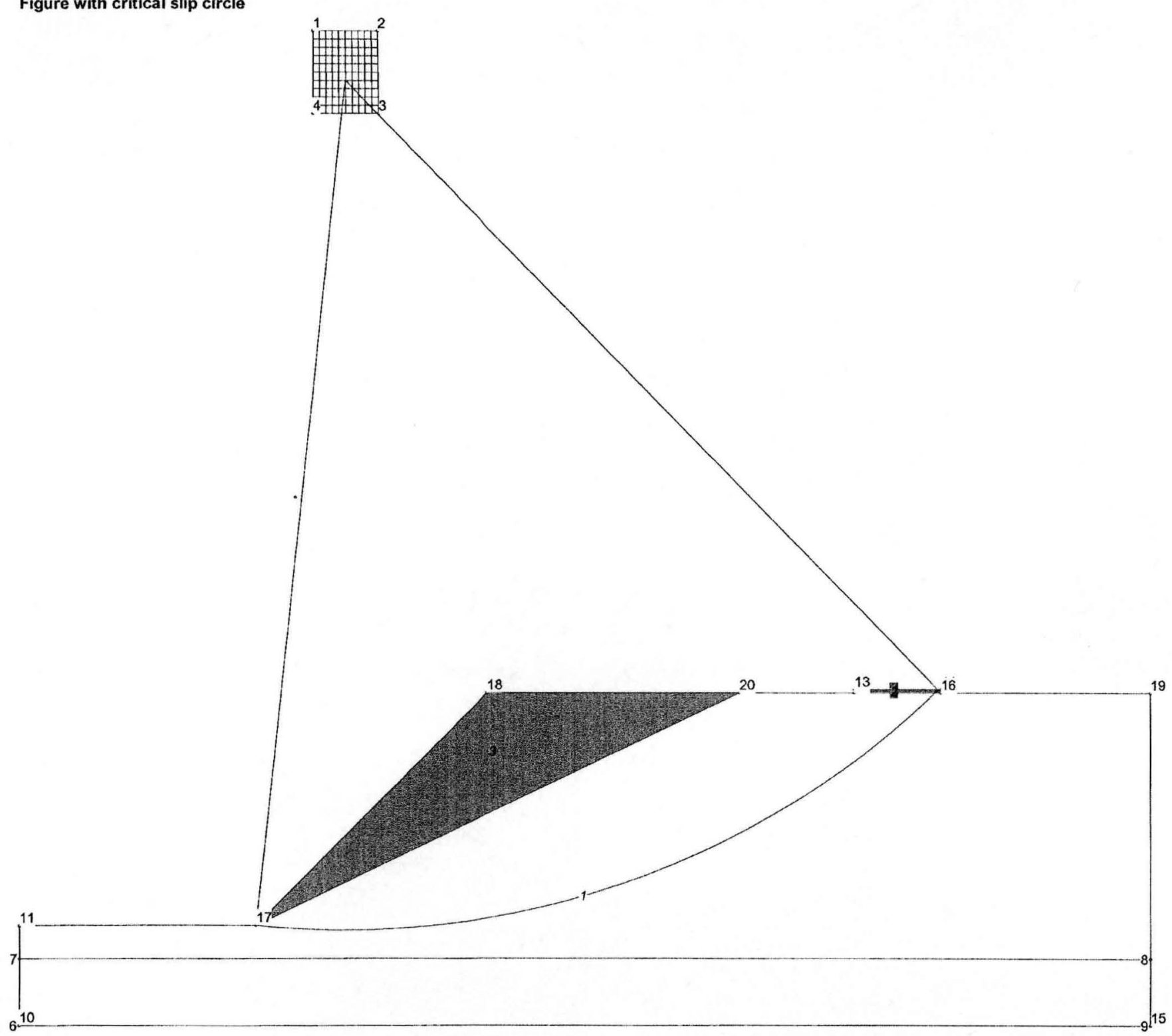

$F=1.332$

Input Data

Coordinates of Nodes

$\begin{array}{ccc}\text { Node } & x & y \\ 1 & 8.711 & 29.877 \\ 2 & 10.668 & 29.877 \\ 3 & 10.708 & 27.390 \\ 4 & 8.711 & 27.390\end{array}$


STB2006 - Slope Stability

David S. Messinger, Load Case 3

$\begin{array}{ccc}5 & 7.000 & 3.000 \\ 6 & 0.000 & 0.000 \\ 7 & 0.000 & 2.000 \\ 8 & 33.974 & 2.000 \\ 9 & 33.974 & 0.000 \\ 10 & 0.000 & 0.000 \\ 11 & 0.000 & 3.000 \\ 12 & 24.986 & 10.000 \\ 13 & 24.986 & 10.100 \\ 14 & 27.611 & 10.100 \\ 15 & 33.974 & 0.000 \\ 16 & 27.611 & 10.000 \\ 17 & 7.000 & 3.000 \\ 18 & 14.000 & 10.000 \\ 19 & 33.974 & 10.000 \\ 20 & 21.560 & 10.000\end{array}$

Structure of Polygons

Window of centers of slip circles

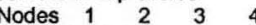

Fixed point of all slip circles

Water Polygon

$$
\text { Nodes }
$$

Soil Polygons

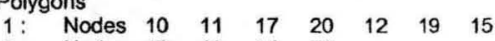

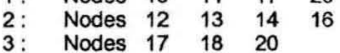

Properties of Soils

$\begin{array}{rcccccccc}\text { Soil } & \begin{array}{c}W d \\ \mathrm{kN} / \mathrm{m}^{3}\end{array} & \begin{array}{c}\mathrm{Ws} \\ \mathrm{kN} / \mathrm{m}^{3}\end{array} & \begin{array}{c}\mathrm{Ko} \\ \end{array} & \begin{array}{c}\mathrm{c} \\ \mathrm{kN} / \mathrm{m}^{2}\end{array} & \begin{array}{c}\mathrm{phl} \\ \text { degrees }\end{array} & \mathrm{P} / \mathrm{F} & \begin{array}{c}\mathrm{p}=0 \\ \mathrm{~m}\end{array} & \begin{array}{c}\text { cap } \\ \mathrm{m}\end{array} \\ 1 & 110.000 & 110.000 & 1.000 & 0.000 & 32.000 & \mathrm{P} & & 0.000 \\ 2 & 12571.430 & 12571.430 & 1.000 & 0.000 & 0.000 & \mathrm{P} & & 0.000 \\ 3 & 0.000 & 10.000 & 1.000 & 0.000 & 0.000 & \mathrm{P} & & 0.000\end{array}$

\section{Output Data}

Safety Factors

\begin{tabular}{|c|c|c|c|c|c|c|c|c|c|c|}
\hline 1.546 & 1.535 & 1.522 & 1.510 & 1.502 & 1.489 & 1.476 & 1.463 & 1.453 & 1.442 & 1.432 \\
\hline 1.516 & 1.503 & 1.492 & 1.480 & 1.469 & 1.459 & 1.446 & 1.436 & 1.422 & 1.410 & 1.397 \\
\hline 1.486 & 1.474 & 1.463 & 1.451 & 1.440 & 1.427 & 1.416 & 1.404 & 1.391 & 1.380 & 1.367 \\
\hline 1.458 & 1.445 & 1.432 & 1.421 & 1.409 & 1.398 & 1.385 & 1.375 & 1.362 & 1.341 & 1.337 \\
\hline 1.427 & 1.414 & 1.404 & 1.393 & 1.380 & 1.370 & 1.357 & 1.334 & 1.338 & 1.338 & 1.339 \\
\hline 1.399 & 1.389 & 1.376 & 1.363 & 1.346 & 1.336 & 1.332 & 1.332 & 1.339 & 1.340 & 1.342 \\
\hline 1.370 & 1.359 & 1.336 & 1.333 & 1.333 & 1.333 & 1.334 & 1.335 & 1.338 & 1.339 & 1.344 \\
\hline 1.335 & 1.333 & 1.333 & 1.333 & 1.333 & 1.336 & 1.337 & 1.339 & 1.343 & 1.345 & 1.351 \\
\hline 1.333 & 1.333 & 1.335 & 1.336 & 1.337 & 1.341 & 1.342 & 1.347 & 1.350 & 1.356 & 1.363 \\
\hline 1.335 & 1.336 & 1.337 & 1.341 & 1.342 & 1.347 & 1.350 & 1.356 & 1.362 & 1.367 & 1.375 \\
\hline 1.337 & 1.341 & 1.343 & 1.347 & 1.350 & 1.356 & 1.362 & 1.367 & 1.375 & 1.384 & 1.395 \\
\hline
\end{tabular}

Critical slip circle

Center: $x=9.701, y=28.385$, Radius: $25.528, F=1.332$
APPENDIX A

CALC. NO. 122633-C-004 


\section{David S. Messinger, P.E., Load Case 3}

\section{General Data}

\section{Licensed User}

File Name

Problem Name

Number of Slices

Relative Horizontal Force: 1000

Number of Nodes : 20

Number of Soil Polygons : 3

Figure with critical slip circle

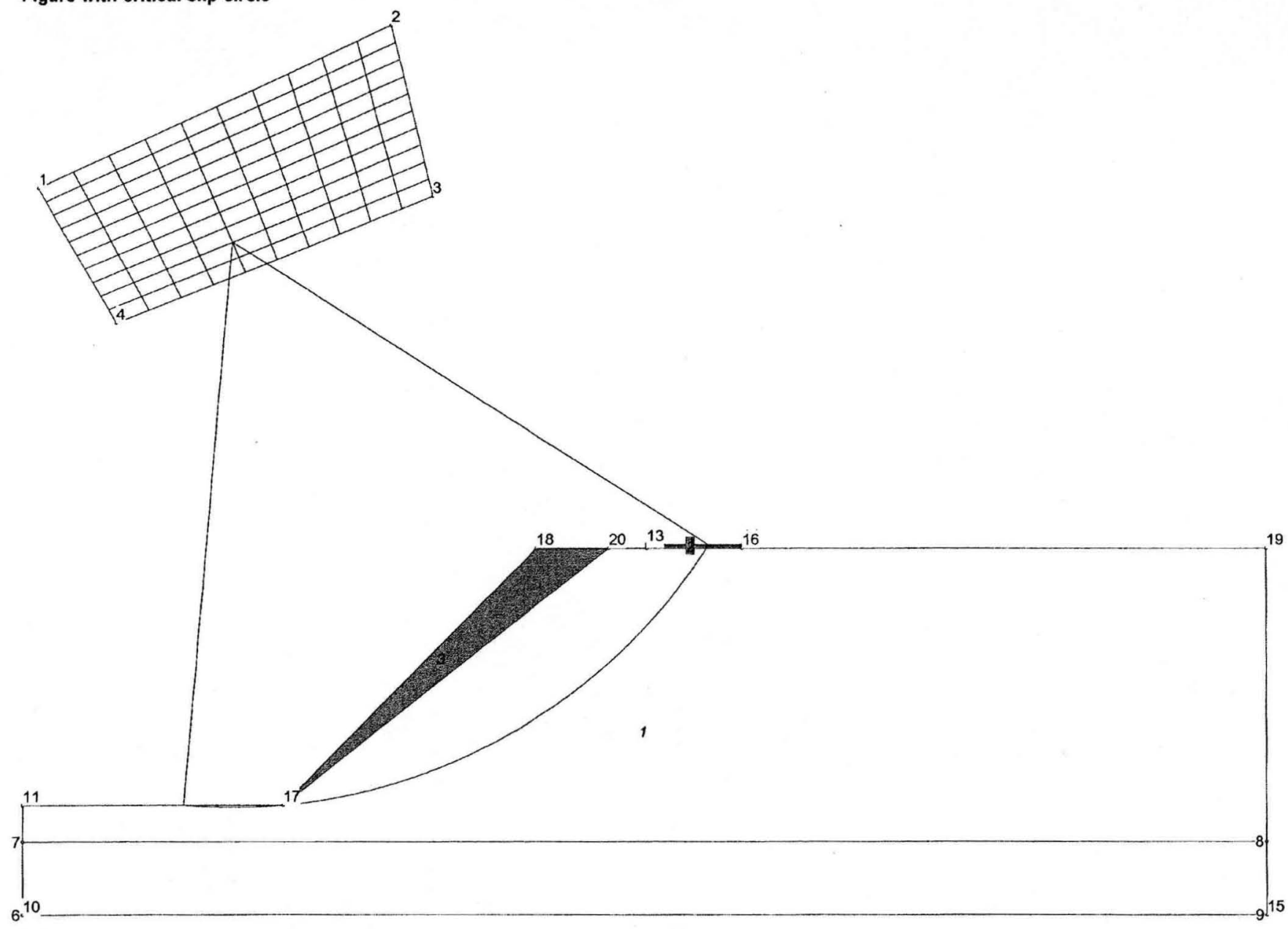

$F=1.076$

Input Data

Coordinates of Nodes

$\begin{array}{ccc}\text { Node } & \mathrm{x} & \mathrm{y} \\ 1 & 0.461 & 19.840 \\ 2 & 10.044 & 24.292 \\ 3 & 11.176 & 19.613 \\ 4 & 2.574 & 16.142 \\ 5 & 7.000 & 3.000 \\ 6 & 0.000 & 0.000 \\ 7 & 0.000 & 2.000 \\ 8 & 33.974 & 2.000 \\ 9 & 33.974 & 0.000 \\ 10 & 0.000 & 0.000 \\ 11 & 0.000 & 3.000 \\ 12 & 16.986 & 10.000 \\ 13 & 16.986 & 10.100 \\ 14 & 19.611 & 10.100 \\ 15 & 33.974 & 0.000\end{array}$


STB2006 - Slope Stability

David S. Messinger, P.E., Load Case 3

$\begin{array}{lll}16 & 19.611 & 10.000 \\ 17 & 7.000 & 3.000 \\ 18 & 14.000 & 10.000 \\ 19 & 33.974 & 10.000 \\ 20 & 15.959 & 10.000\end{array}$

Structure of Polygons

Window of centers of slip circles

$$
\text { Nodes } \begin{array}{llll}
1 & 2 & 3 & 4
\end{array}
$$

Fixed point of all slip circles

Node 5

Water Polygon

Nodes $\begin{array}{lllll}6 & 7 & 8 & 9\end{array}$

Soil Polygons

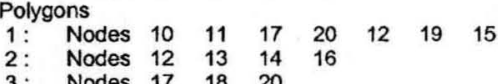

3: Nodes $17 \quad 18 \quad 20$

Properties of Soils

$\begin{array}{ccccccccc}\text { Soil } & \begin{array}{c}\text { Wd } \\ \mathrm{kN} / \mathrm{m}^{3}\end{array} & \begin{array}{c}\mathrm{Ws} \\ \mathrm{kN} / \mathrm{m}^{3}\end{array} & \begin{array}{l}\mathrm{Ko} \\ \end{array} & \begin{array}{c}\mathrm{C} \\ \mathrm{kN} / \mathrm{m}^{2}\end{array} & \begin{array}{c}\mathrm{phi} \\ \text { degrees }\end{array} & \mathrm{P} / \mathrm{F} & \begin{array}{c}\mathrm{p}=0 \\ \mathrm{~m}\end{array} & \begin{array}{c}\text { cap } \\ \mathrm{m}\end{array} \\ 1 & 110.000 & 110.000 & 1.000 & 0.000 & 38.000 & \mathrm{P} & & 0.000 \\ 2 & 12571.430 & 12571.430 & 1.000 & 0.000 & 0.000 & \mathrm{P} & & 0.000 \\ 3 & 110.000 & 110.000 & 1.000 & 0.000 & 38.000 & \mathrm{P} & & 0.000\end{array}$

CALC. NO. 122633-C-004
Appendix Page 13 of 43

Page 2

Output Data

Safety Factors

$\begin{array}{lllllllllll}2.394 & 2.389 & 2.387 & 2.383 & 2.381 & 2.378 & 2.375 & 2.372 & 2.373 & 2.372 & 2.370 \\ 2.102 & 2.098 & 2.092 & 2.087 & 2.082 & 2.080 & 2.076 & 2.069 & 2.066 & 2.063 & 2.061 \\ 1.843 & 1.836 & 1.830 & 1.824 & 1.818 & 1.811 & 1.805 & 1.800 & 1.794 & 1.790 & 1.784 \\ 1.609 & 1.602 & 1.594 & 1.587 & 1.581 & 1.572 & 1.565 & 1.559 & 1.552 & 1.544 & 1.537 \\ 1.400 & 1.393 & 1.385 & 1.376 & 1.367 & 1.360 & 1.350 & 1.342 & 1.335 & 1.327 & 1.318 \\ 1.219 & 1.209 & 1.198 & 1.189 & 1.179 & 1.169 & 1.160 & 1.151 & 1.141 & 1.124 & 1.125 \\ 1.106 & 1.100 & 1.094 & 1.088 & 1.084 & 1.081 & 1.079 & 1.077 & 1.076 & 1.078 & 1.079 \\ 1.125 & 1.115 & 1.109 & 1.103 & 1.098 & 1.095 & 1.092 & 1.093 & 1.095 & 1.099 & 1.107 \\ 1.290 & 1.293 & 1.296 & 1.322 & 1.325 & 1.353 & 1.336 & 1.312 & 1.290 & 1.269 & 1.250 \\ 1.498 & 1.488 & 1.476 & 1.463 & 1.449 & 1.432 & 1.413 & 1.392 & 1.367 & 1.340 & 1.309 \\ 1.577 & 1.577 & 1.576 & 1.574 & 1.571 & 1.565 & 1.556 & 1.546 & 1.533 & 1.517 & 1.498\end{array}$

Critical slip circle

Center: $x=$ 5.671, $y=18.349$, Radius: $15.406, F=1.076$ 
David S. Messinger, P.E., Load Case 3

\section{General Data}

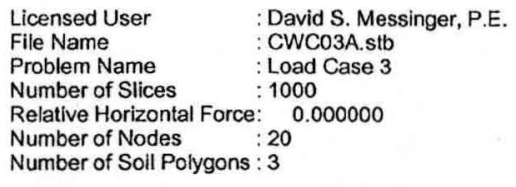

Figure with critical slip circle

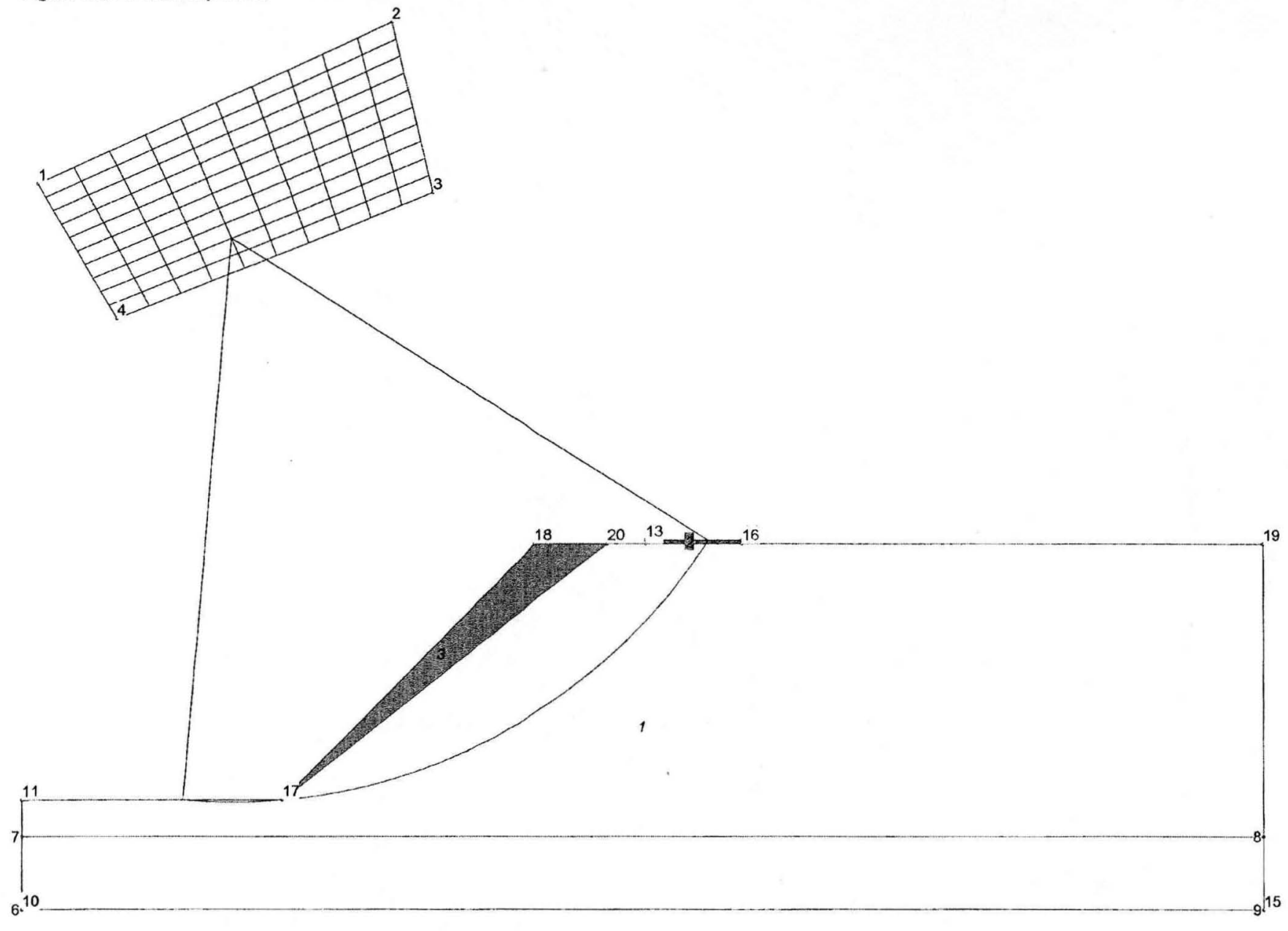

$F=1.076$

Input Data

\section{Coordinates of Nodes}

$\begin{array}{ccc}\text { Node } & \mathrm{x} & \mathrm{y} \\ 1 & 0.461 & 19.840 \\ 2 & 10.044 & 24.292 \\ 3 & 11.176 & 19.613 \\ 4 & 2.574 & 16.142 \\ 5 & 7.000 & 3.000 \\ 6 & 0.000 & 0.000 \\ 7 & 0.000 & 2.000 \\ 8 & 33.974 & 2.000 \\ 9 & 33.974 & 0.000 \\ 10 & 0.000 & 0.000 \\ 11 & 0.000 & 3.000 \\ 12 & 16.986 & 10.000 \\ 13 & 16.986 & 10.100 \\ 14 & 19.611 & 10.100 \\ 15 & 33.974 & 0.000\end{array}$


STB2006 - Slope Stability

David S. Messinger, P.E., Load Case 3

$\begin{array}{lll}16 & 19.611 & 10.000 \\ 17 & 7.000 & 3.000 \\ 18 & 14.000 & 10.000 \\ 19 & 33.974 & 10.000 \\ 20 & 15.959 & 10.000\end{array}$

Structure of Polygons

Window of centers of slip circles

$$
\text { Nodes } \begin{array}{llll}
1 & 2 & 3 & 4
\end{array}
$$

Fixed point of all slip circles$$
\text { Node }
$$

Water Polys

$$
\text { Nodes }
$$

Soil Polygons

$\begin{array}{lllll}6 & 7 & 8 & 9\end{array}$

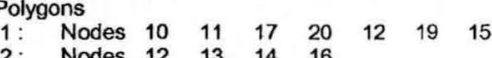

$\begin{array}{llllll}2: & \text { Nodes } & 12 & 13 & 14 & 16 \\ \text { 3: } & \text { Nodes } & 17 & 18 & 20 & \end{array}$

Properties of Soils

$\begin{array}{ccccccccc}\text { Soil } & \begin{array}{c}W d \\ \mathrm{kN} / \mathrm{m}^{3}\end{array} & \begin{array}{c}W \mathrm{WN} \\ \mathrm{kN} / \mathrm{m}^{3}\end{array} & \begin{array}{c}\mathrm{Ko} \\ \end{array} & \begin{array}{c}\mathrm{c} \\ \mathrm{kN} / \mathrm{m}^{2}\end{array} & \begin{array}{c}\mathrm{phi} \\ \text { degrees }\end{array} & \mathrm{P} / \mathrm{F} & \begin{array}{c}\mathrm{p}=0 \\ \mathrm{~m}\end{array} & \begin{array}{c}\text { cap } \\ \mathrm{m}\end{array} \\ 1 & 110.000 & 110.000 & 1.000 & 0.000 & 38.000 & \mathrm{P} & & 0.000 \\ 2 & 12571.430 & 12571.430 & 1.000 & 0.000 & 0.000 & \mathrm{P} & & 0.000 \\ 3 & 110.000 & 110.000 & 1.000 & 0.000 & 38.000 & \mathrm{P} & & 0.000\end{array}$

\section{Output Data}

\section{Safety Factors}

$\begin{array}{lllllllllll}2.394 & 2.389 & 2.387 & 2.383 & 2.381 & 2.378 & 2.375 & 2.372 & 2.373 & 2.372 & 2.370 \\ 2.102 & 2.098 & 2.092 & 2.087 & 2.082 & 2.080 & 2.076 & 2.069 & 2.066 & 2.063 & 2.061 \\ 1.843 & \mathbf{1 . 8 3 6} & 1.830 & 1.824 & 1.818 & 1.811 & 1.805 & 1.800 & 1.794 & 1.790 & 1.784 \\ 1.609 & \mathbf{1 . 6 0 2} & 1.594 & 1.587 & 1.581 & 1.572 & 1.565 & 1.559 & 1.552 & 1.544 & 1.537 \\ 1.400 & 1.393 & 1.385 & 1.376 & 1.367 & 1.360 & 1.350 & 1.342 & 1.335 & 1.327 & 1.318 \\ 1.219 & 1.209 & 1.198 & 1.189 & 1.179 & 1.169 & 1.160 & 1.151 & 1.141 & 1.124 & 1.125 \\ 1.106 & 1.100 & 1.094 & 1.088 & 1.084 & 1.081 & 1.079 & 1.077 & 1.076 & 1.078 & 1.079 \\ 1.125 & 1.115 & 1.109 & 1.103 & 1.098 & 1.095 & 1.092 & 1.093 & 1.095 & 1.099 & 1.107 \\ 1.290 & 1.293 & 1.296 & 1.322 & 1.325 & 1.353 & 1.336 & 1.312 & 1.290 & 1.269 & 1.250 \\ 1.498 & 1.488 & 1.476 & 1.463 & 1.449 & 1.432 & 1.413 & 1.392 & 1.367 & 1.340 & 1.309 \\ 1.577 & 1.577 & 1.576 & 1.574 & 1.571 & 1.565 & 1.556 & 1.546 & 1.533 & 1.517 & 1.498\end{array}$

Critical slip circle

Center: $x=$ 5.671, $y=18.349$, Radius: $15.406, F=1.076$
APPENDIX A

CALC. NO. 122633-C-004
Appendix Page 15 of 43

Page 2 
STB2006 - Slope Stability

Copyright $\odot 2006$ by A. Verruijt

\section{APPENDIX A}

CALC. NO. 122633-C-004
Appendix Page 16 of 43

Page 1

David S. Messinger, P.E., Load Case 3B

General Data

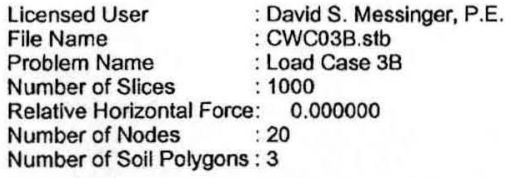

Figure with critical slip circle

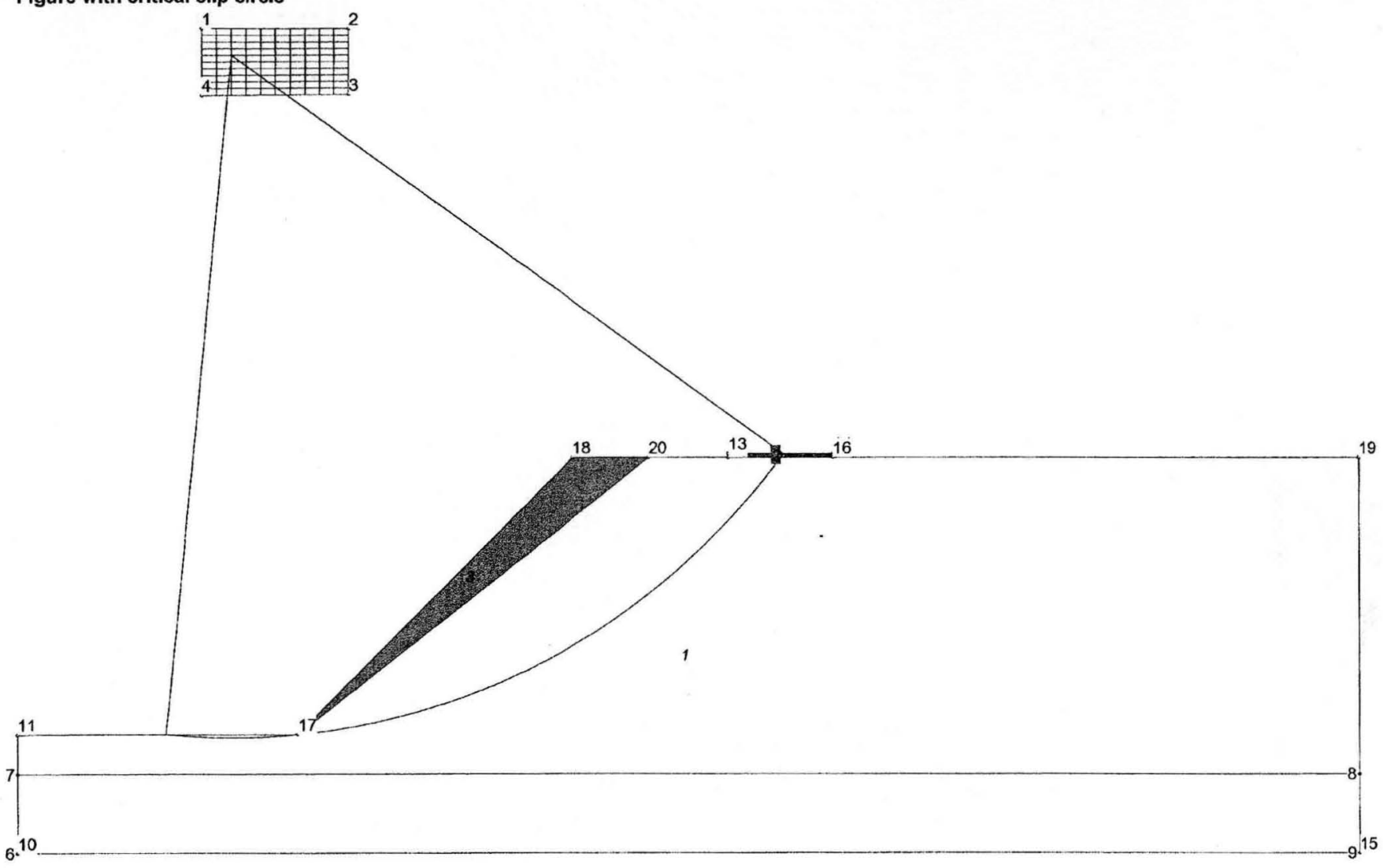

$F=1.104$

Input Data

Coordinates of Nodes

$\begin{array}{ccc}\text { Node } & x & y \\ 1 & 4.596 & 20.897 \\ 2 & 8.327 & 20.897 \\ 3 & 8.327 & 19.231 \\ 4 & 4.596 & 19.198 \\ 5 & 7.000 & 3.000 \\ 6 & 0.000 & 0.000 \\ 7 & 0.000 & 2.000 \\ 8 & 33.974 & 2.000 \\ 9 & 33.974 & 0.000 \\ 10 & 0.000 & 0.000 \\ 11 & 0.000 & 3.000 \\ 12 & 17.986 & 10.000 \\ 13 & 17.986 & 10.100 \\ 14 & 20.611 & 10.100 \\ 15 & 33.974 & 0.000 \\ 16 & 20.611 & 10.000 \\ 17 & 7.000 & 3.000 \\ 18 & 14.000 & 10.000 \\ 19 & 33.974 & 10.000 \\ 20 & 15.959 & 10.000\end{array}$




\section{STB2006 - Slope Stability}

David S. Messinger, P.E., Load Case 3B

\section{Structure of Polygons}

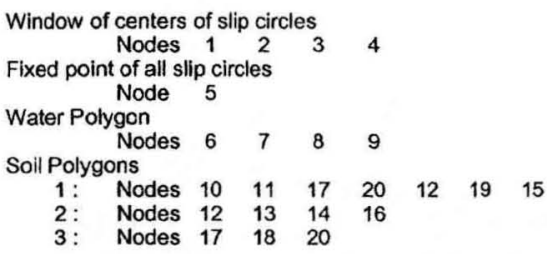

Properties of Solls

$\begin{array}{ccccccccc}\text { Soil } & \begin{array}{c}W d \\ \mathrm{kN} / \mathrm{m}^{3}\end{array} & \begin{array}{c}\mathrm{Ws} \\ \mathrm{kN} / \mathrm{m}^{3}\end{array} & \begin{array}{c}\mathrm{Ko} \\ \end{array} & \begin{array}{c}\mathrm{c} \\ \mathrm{kN} / \mathrm{m}^{2}\end{array} & \begin{array}{c}\mathrm{phi} \\ \text { degrees }\end{array} & \begin{array}{c}\mathrm{P} / \mathrm{F} \\ \mathrm{p}=0\end{array} & \begin{array}{c}\text { cap } \\ \mathrm{m}\end{array} \\ 1 & 110.000 & 110.000 & 1.000 & 0.000 & 38.000 & \mathrm{P} & & 0.000 \\ 2 & 12571.430 & 12571.430 & 1.000 & 0.000 & 0.000 & \mathrm{P} & & 0.000 \\ 3 & 0.000 & 10.000 & 1.000 & 0.000 & 0.000 & \mathrm{P} & & 0.000\end{array}$

\section{Output Data}

Safety Factors

\begin{tabular}{|c|c|c|c|c|c|c|c|c|c|c|}
\hline 1.511 & 1.499 & 1.484 & 1.470 & 1.456 & 1.442 & 1.428 & 1.414 & 1.400 & 1.386 & 1.371 \\
\hline 1.437 & 1.423 & 1.409 & 1.395 & 1.381 & 1.368 & 1.353 & 1.339 & 1.324 & 1.311 & 1.296 \\
\hline 1.365 & 1.352 & 1.339 & 1.324 & 1.310 & 1.296 & 1.282 & 1.268 & 1.254 & 1.240 & 1.226 \\
\hline 1.298 & 1.284 & 1.271 & 1.257 & 1.242 & 1.228 & 1.214 & 1.200 & 1.187 & 1.173 & 1.149 \\
\hline 1.234 & 1.219 & 1.206 & 1.193 & 1.179 & 1.165 & 1.143 & 1.139 & 1.135 & 1.131 & 1.128 \\
\hline 1.172 & 1.152 & 1.139 & 1.134 & 1.130 & 1.126 & 1.122 & 1.125 & 1.122 & 1.119 & 1.117 \\
\hline 1.133 & 1.129 & 1.125 & 1.122 & 1.119 & 1.116 & 1.113 & 1.111 & 1.109 & 1.109 & 1.108 \\
\hline 1.118 & 1.114 & 1.111 & 1.109 & 1.107 & 1.106 & 1.105 & 1.104 & 1.104 & 1.106 & 1.107 \\
\hline 1.108 & 1.107 & 1.104 & 1.104 & 1.104 & 1.104 & 1.105 & 1.107 & 1.111 & 1.115 & 1.122 \\
\hline 1.106 & 1.106 & 1.108 & 1.110 & 1.113 & 1.116 & 1.121 & 1.127 & 1.133 & 1.142 & 1.155 \\
\hline 1.116 & 1.120 & 1.125 & 1.129 & 1.136 & 1.144 & 1.155 & 1.167 & 1.186 & 1.204 & 1.224 \\
\hline
\end{tabular}

Critical slip circle

Center: $x=5.343, y=20.220$, Radius: $17.300, F=1.104$
Page 2 
STB2006 - Slope Stability

APPENDIX A

Copyright (c) 2006 by A. Verruijt

CALC. NO. 122633-C-004

Page 1

David S. Messinger, Load Case 4

General Data

Licensed User $\quad$ : David S. Messinger

File Name :CWC04.stb

Problem Name $\quad$ : Load Case 4

Number of Slices $\quad: 1000$

Relative Horizontal Force: 0.000000

Number of Nodes $: 20$

Number of Soil Polygons : 3

Figure with critical slip circle

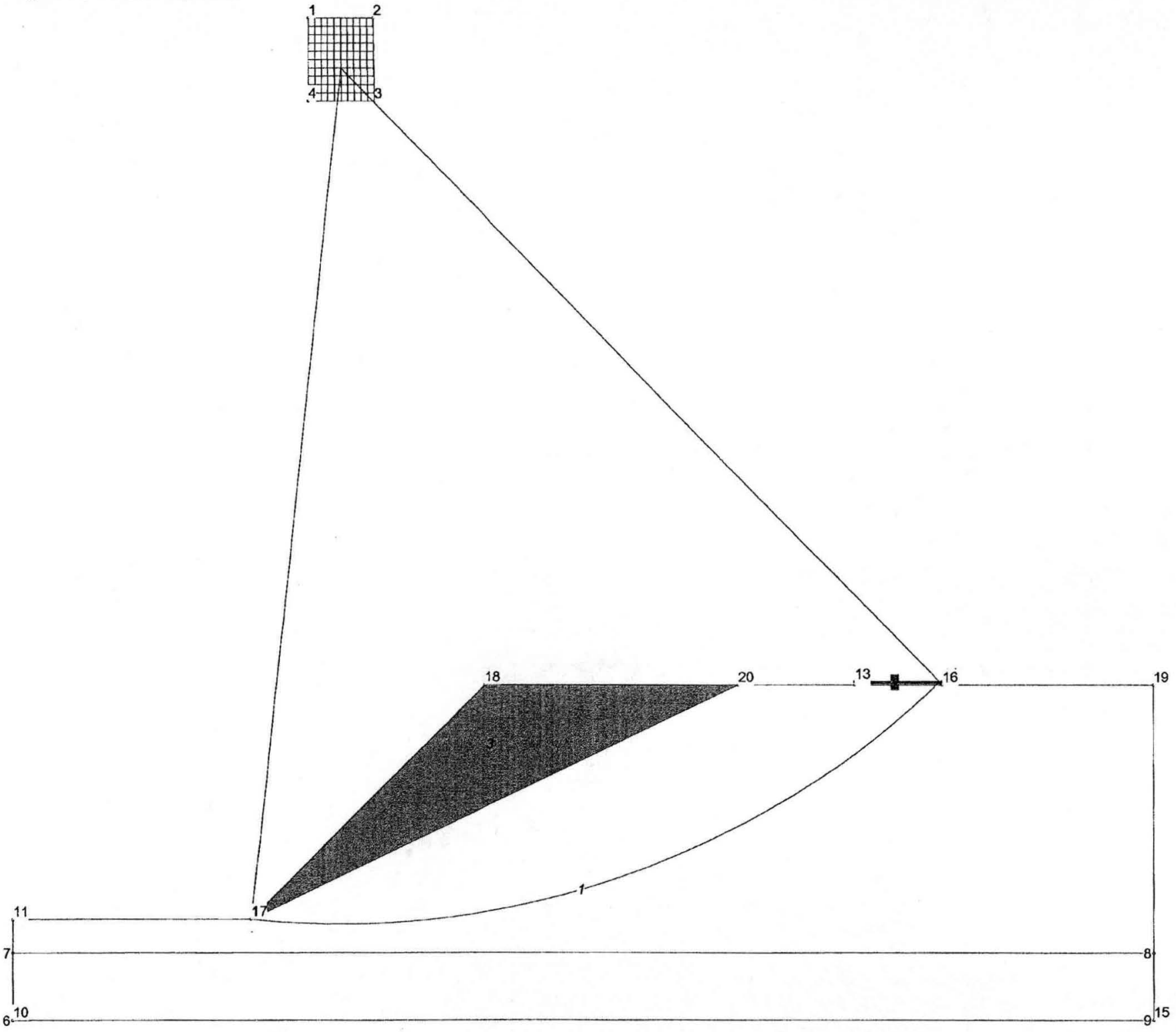

$F=1.332$

Input Data

Coordinates of Nodes

$\begin{array}{ccc}\text { Node } & x & y \\ 1 & 8.711 & 29.877 \\ 2 & 10.668 & 29.877 \\ 3 & 10.708 & 27.390 \\ 4 & 8.711 & 27.390\end{array}$


STB2006 - Slope Stability

David S. Messinger, Load Case 4

$\begin{array}{ccc}5 & 7.000 & 3.000 \\ 6 & 0.000 & 0.000 \\ 7 & 0.000 & 2.000 \\ 8 & 33.974 & 2.000 \\ 9 & 33.974 & 0.000 \\ 10 & 0.000 & 0.000 \\ 11 & 0.000 & 3.000 \\ 12 & 24.986 & 10.000 \\ 13 & 24.986 & 10.100 \\ 14 & 27.611 & 10.100 \\ 15 & 33.974 & 0.000 \\ 16 & 27.611 & 10.000 \\ 17 & 7.000 & 3.000 \\ 18 & 14.000 & 10.000 \\ 19 & 33.974 & 10.000 \\ 20 & 21.560 & 10.000\end{array}$

\section{Structure of Polygons}

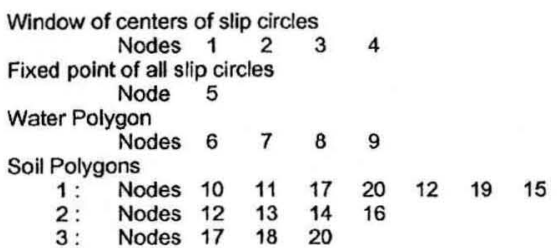

Properties of Soils

$\begin{array}{ccccccccc}\text { Soil } & \begin{array}{c}W d \\ \mathrm{kN} / \mathrm{m}^{3}\end{array} & \begin{array}{c}\mathrm{Ws} \\ \mathrm{kN} / \mathrm{m}^{3}\end{array} & \begin{array}{c}\mathrm{Ko} \\ \end{array} & \begin{array}{c}\mathrm{c} \\ \mathrm{kN} / \mathrm{m}^{2}\end{array} & \begin{array}{c}\mathrm{phi} \\ \text { degrees }\end{array} & \mathrm{P} / \mathrm{F} & \begin{array}{c}\mathrm{p}=0 \\ \mathrm{~m}\end{array} & \begin{array}{c}\text { cap } \\ \mathrm{m}\end{array} \\ 1 & 110.000 & 110.000 & 1.000 & 0.000 & 32.000 & \mathrm{P} & & 0.000 \\ 2 & 12571.430 & 12571.430 & 1.000 & 0.000 & 0.000 & \mathrm{P} & & 0.000 \\ 3 & 0.000 & 10.000 & 1.000 & 0.000 & 0.000 & \mathrm{P} & & 0.000\end{array}$

\section{Output Data}

\section{Safety Factors}

$\begin{array}{lllllllllll}1.546 & 1.535 & 1.522 & 1.510 & 1.502 & 1.489 & 1.476 & 1.465 & 1.453 & 1.442 & 1.432 \\ 1.516 & 1.503 & 1.492 & 1.480 & 1.469 & 1.459 & 1.446 & 1.436 & 1.422 & 1.410 & 1.397 \\ 1.486 & 1.474 & 1.463 & 1.451 & 1.440 & 1.427 & 1.416 & 1.404 & 1.391 & 1.380 & 1.367 \\ 1.458 & \mathbf{1 . 4 4 5} & 1.432 & 1.421 & 1.409 & 1.398 & 1.385 & 1.375 & 1.362 & 1.341 & 1.337 \\ 1.427 & 1.414 & 1.404 & 1.393 & 1.380 & 1.370 & 1.357 & 1.334 & 1.338 & 1.338 & 1.339 \\ 1.399 & 1.389 & 1.376 & 1.363 & 1.346 & 1.336 & 1.332 & 1.332 & 1.339 & 1.340 & 1.342 \\ 1.370 & 1.359 & 1.336 & 1.333 & 1.333 & 1.333 & 1.334 & 1.335 & 1.338 & 1.339 & 1.344 \\ 1.335 & 1.333 & 1.333 & 1.333 & 1.333 & 1.336 & 1.337 & 1.339 & 1.343 & 1.345 & 1.351 \\ 1.333 & 1.333 & 1.335 & 1.336 & 1.337 & 1.341 & 1.342 & 1.347 & 1.350 & 1.356 & 1.363 \\ 1.335 & 1.336 & 1.337 & 1.341 & 1.342 & 1.347 & 1.350 & 1.356 & 1.362 & 1.367 & 1.375 \\ 1.337 & 1.341 & 1.343 & 1.347 & 1.350 & 1.356 & 1.362 & 1.367 & 1.375 & 1.384 & 1.395\end{array}$

Critical slip circle

Center: $x=9.702, y=28.385$, Radius: $25.528, F=1.332$ 
STB2006 - Slope Stability Copyright $\odot 2006$ by A. Verrujitt

David S. Messinger, P.E., Load Case 4A

\title{
General Data
}

Licensed User File Name

Problem Name

Number of Slices

CWC04A.stb

: Load Case 4A

Number of Nodes

0.000000

Number of Soil Polygons : 3

\begin{abstract}
Figure with critical slip circle
\end{abstract}
APPENDIX A

CALC. NO. 122633-C-004
Appendix Page 20 of 43

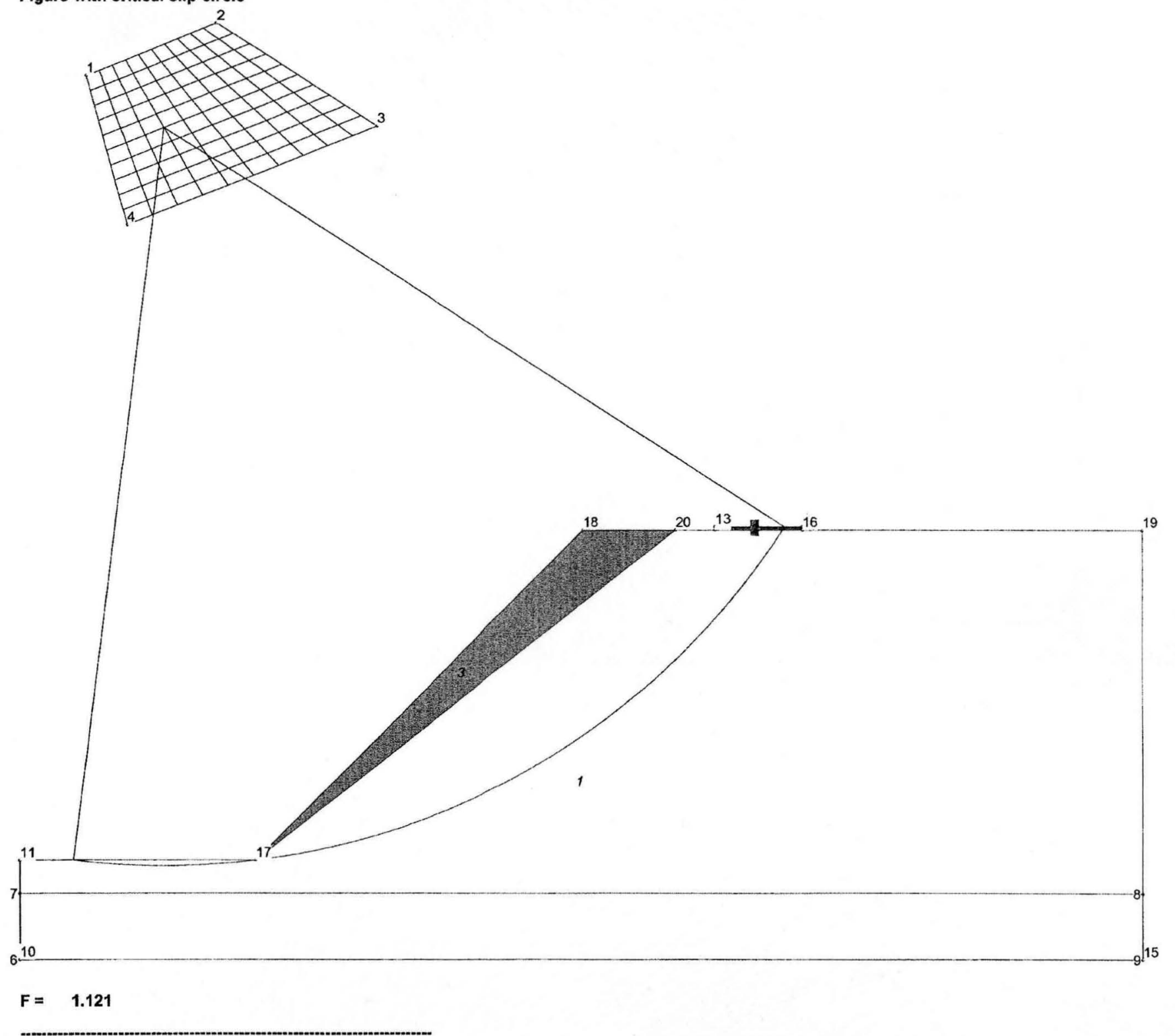

Input Data

\section{Coordinates of Nodes}

$\begin{array}{ccc}\text { Node } & x & y \\ 1 & 2.000 & 26.734 \\ 2 & 5.868 & 28.333 \\ 3 & 10.702 & 25.228 \\ 4 & 3.207 & 22.212 \\ 5 & 7.000 & 3.000 \\ 6 & 0.000 & 0.000 \\ 7 & 0.000 & 2.000\end{array}$


STB2006 - Slope Stability

David S. Messinger, P.E., Load Case 4A

APPENDIX A

CALC. NO. 122633-C-004
Appendix Page 21 of 43

Page 2

$\begin{array}{ccc}8 & 34.000 & 2.000 \\ 9 & 34.000 & 0.000 \\ 10 & 0.000 & 0.000 \\ 11 & 0.000 & 3.000 \\ 12 & 21.000 & 13.000 \\ 13 & 21.000 & 13.100 \\ 14 & 23.625 & 13.100 \\ 15 & 34.000 & 0.000 \\ 16 & 23.625 & 13.000 \\ 17 & 7.000 & 3.000 \\ 18 & 17.000 & 13.000 \\ 19 & 34.000 & 13.000 \\ 20 & 19.799 & 13.000\end{array}$

\section{Structure of Polygons}

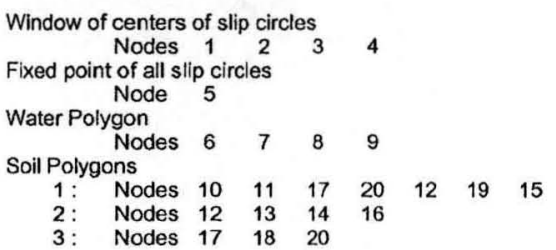

Properties of Soils

$\begin{array}{ccccccccc}\text { Soil } & \begin{array}{c}W d \\ \mathbf{k N} / \mathrm{m}^{3}\end{array} & \begin{array}{c}\mathrm{Ws} \\ \mathrm{kN} / \mathrm{m}^{3}\end{array} & \begin{array}{c}\mathrm{Ko} \\ \end{array} & \begin{array}{c}\mathrm{c} \\ \mathbf{k N} / \mathrm{m}^{2}\end{array} & \begin{array}{c}\mathrm{phi} \\ \text { degrees }\end{array} & \begin{array}{c}\mathrm{P} / \mathrm{F} \\ \mathrm{p}=0\end{array} & \begin{array}{c}\text { cap } \\ \mathrm{m}\end{array} \\ 1 & 110.000 & 110.000 & 1.000 & 0.000 & 38.000 & \mathrm{P} & & 0.000 \\ 2 & 12571.430 & 12571.430 & 1.000 & 0.000 & 0.000 & \mathrm{P} & & 0.000 \\ 3 & 110.000 & 110.000 & 1.000 & 0.000 & 38.000 & \mathrm{P} & & 0.000\end{array}$

\section{Output Data}

\section{Safety Factors}

$\begin{array}{lllllllllll}1.423 & 1.464 & 1.510 & 1.558 & 1.609 & 1.664 & 1.719 & 1.780 & 1.846 & 1.915 & 1.989 \\ 1.370 & 1.403 & 1.440 & 1.479 & 1.522 & 1.566 & 1.612 & 1.661 & 1.716 & 1.771 & 1.831 \\ 1.319 & 1.344 & 1.373 & 1.404 & 1.438 & 1.473 & 1.509 & 1.549 & 1.592 & 1.635 & 1.683 \\ 1.270 & 1.288 & 1.310 & 1.333 & 1.358 & 1.384 & 1.412 & 1.442 & 1.474 & 1.508 & 1.544 \\ 1.223 & 1.235 & 1.249 & 1.264 & 1.280 & 1.299 & 1.320 & 1.341 & 1.364 & 1.389 & 1.414 \\ 1.181 & 1.186 & 1.194 & 1.200 & 1.210 & 1.221 & 1.233 & 1.247 & 1.260 & 1.276 & 1.291 \\ 1.136 & 1.133 & 1.133 & 1.135 & 1.140 & 1.149 & 1.152 & 1.157 & 1.164 & 1.170 & 1.178 \\ 1.133 & 1.129 & 1.132 & 1.129 & 1.122 & 1.121 & 1.121 & 1.122 & 1.124 & 1.125 & 1.129 \\ 1.136 & 1.133 & 1.137 & 1.135 & 1.132 & 1.131 & 1.128 & 1.129 & 1.132 & 1.133 & 1.136 \\ 1.146 & 1.145 & 1.152 & 1.154 & 1.154 & 1.158 & 1.161 & 1.165 & 1.171 & 1.179 & 1.191 \\ 1.161 & 1.166 & 1.174 & 1.190 & 1.203 & 1.218 & 1.235 & 1.262 & 1.256 & 1.244 & 1.231\end{array}$

Critical slip circle

Center: $x=4.308, y=25.165$, Radius: $22.328, F=1.121$ 
STB2006 - Slope Stability

APPENDIX A

Copyright $\$ 2006$ by A. Verruijt

David S. Messinger, P.E., Load Case 4B

\section{General Data}

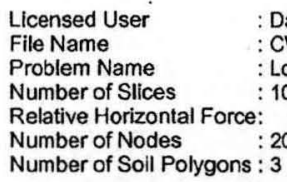

Licensed User File Name

Problem Name

Number of Slices

Relative Horizonta

Number of Soil Polygons : 3

Figure with critical slip circle

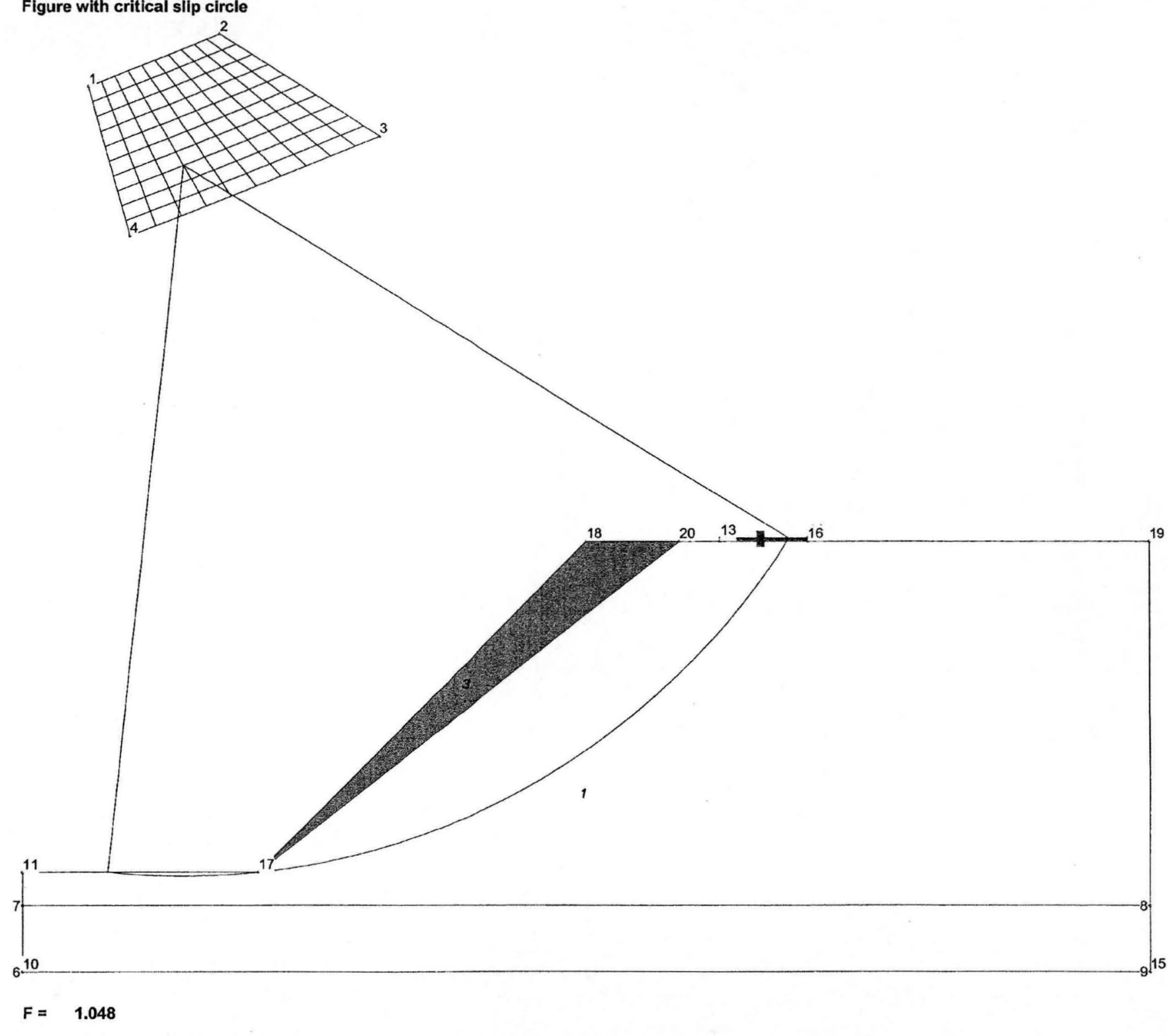

Input Data

Coordinates of Nodes

$\begin{array}{ccc}\text { Node } & x & y \\ 1 & 2.000 & 26.734 \\ 2 & 5.868 & 28.333 \\ 3 & 10.702 & 25.228 \\ 4 & 3.207 & 22.212 \\ 5 & 7.000 & 3.000 \\ 6 & 0.000 & 0.000 \\ 7 & 0.000 & 2.000\end{array}$


STB2006 - Slope Stability

David S. Messinger, P.E., Load Case 4B

$\begin{array}{ccc}8 & 34.000 & 2.000 \\ 9 & 34.000 & 0.000 \\ 10 & 0.000 & 0.000 \\ 11 & 0.000 & 3.000 \\ 12 & 21.000 & 13.000 \\ 13 & 21.000 & 13.100 \\ 14 & 23.625 & 13.100 \\ 15 & 34.000 & 0.000 \\ 16 & 23.625 & 13.000 \\ 17 & 7.000 & 3.000 \\ 18 & 17.000 & 13.000 \\ 19 & 34.000 & 13.000 \\ 20 & 19.799 & 13.000\end{array}$

Structure of Polygons

Window of centers of slip circles

$\begin{array}{lllll}\text { Nodes } & 1 & 2 & 3 & 4\end{array}$

Fixed point of all slip circles

Water Polygon

Soil Polygons

$\begin{array}{llll}7 & 8 & 9\end{array}$

2: $\quad \begin{array}{lllll}\text { Nodes } & 12 & 11 & 17 & 20\end{array}$

3: Nodes $17 \quad 18 \quad 20$

Properties of Soils

$\begin{array}{ccccccccc}\text { Soil } & \begin{array}{c}\text { Wd } \\ \mathrm{kN} / \mathrm{m}^{3}\end{array} & \begin{array}{c}\mathrm{Ws} \\ \mathrm{kN} / \mathrm{m}^{3}\end{array} & \begin{array}{c}\mathrm{Ko} \\ \end{array} & \begin{array}{c}\mathrm{c} \\ \mathrm{kN} / \mathrm{m}^{2}\end{array} & \begin{array}{c}\mathrm{phi} \\ \text { degrees }\end{array} & \begin{array}{c}\mathrm{P} / \mathrm{F} \\ \mathrm{p}=0\end{array} & \begin{array}{c}\text { cap } \\ \mathrm{m}\end{array} \\ 1 & 110.000 & 110.000 & 1.000 & 0.000 & 38.000 & \mathrm{P} & & 0.000 \\ 2 & 12571.430 & 12571.430 & 1.000 & 0.000 & 0.000 & \mathrm{P} & & 0.000 \\ 3 & 0.000 & 10.000 & 1.000 & 0.000 & 0.000 & \mathrm{P} & & 0.000\end{array}$

\section{Output Data}

Safety Factors

$\begin{array}{lllllllllll}1.344 & 1.383 & 1.426 & 1.471 & 1.519 & 1.570 & 1.622 & 1.679 & 1.740 & 1.802 & 1.870 \\ 1.293 & 1.325 & 1.359 & 1.396 & 1.436 & 1.477 & 1.520 & 1.566 & 1.617 & 1.668 & 1.723 \\ 1.244 & 1.267 & 1.295 & 1.324 & 1.355 & 1.388 & 1.422 & 1.460 & 1.499 & 1.539 & 1.584 \\ 1.197 & 1.213 & 1.233 & 1.255 & 1.278 & 1.303 & 1.329 & 1.357 & 1.387 & 1.418 & 1.452 \\ 1.152 & 1.162 & 1.174 & 1.189 & 1.203 & 1.221 & 1.241 & 1.260 & 1.282 & 1.304 & 1.328 \\ 1.111 & 1.115 & 1.121 & 1.126 & 1.135 & 1.145 & 1.156 & 1.169 & 1.181 & 1.195 & 1.210 \\ 1.067 & 1.063 & 1.061 & 1.062 & 1.066 & 1.075 & 1.077 & 1.081 & 1.087 & 1.092 & 1.099 \\ 1.067 & 1.062 & 1.064 & 1.060 & 1.051 & 1.049 & 1.048 & 1.048 & 1.049 & 1.049 & 1.052 \\ 1.076 & 1.071 & 1.076 & 1.073 & 1.069 & 1.067 & 1.064 & 1.064 & 1.067 & 1.069 & 1.072 \\ 1.094 & 1.094 & 1.103 & 1.107 & 1.108 & 1.113 & 1.120 & 1.127 & 1.137 & 1.150 & 1.169 \\ 1.121 & 1.130 & 1.144 & 1.170 & 1.192 & 1.220 & 1.253 & 1.305 & 1.307 & 1.300 & 1.294\end{array}$

Critical slip circle

Center: $x=4.767, y=24.346$, Radius: $21.462, F=1.048$
CALC. NO. 122633-C-004 
STB2006 - Slope Stability

David S. Messinger, P.E., Load Case 5A

\section{General Data}

$$
\begin{array}{ll}
\text { Licensed User } & : \text { David S. Messinger, P.E. } \\
\text { File Name } & : \text { CWCO5A.stb } \\
\text { Problem Name } & : \text { Load Case 5A } \\
\text { Number of Slices } & : 1000 \\
\text { Relative Horizontal Force: } 0.000000 & \\
\text { Number of Nodes } & : 20 \\
\text { Number of Soil Polygons : } 3
\end{array}
$$

Figure with critical slip circle

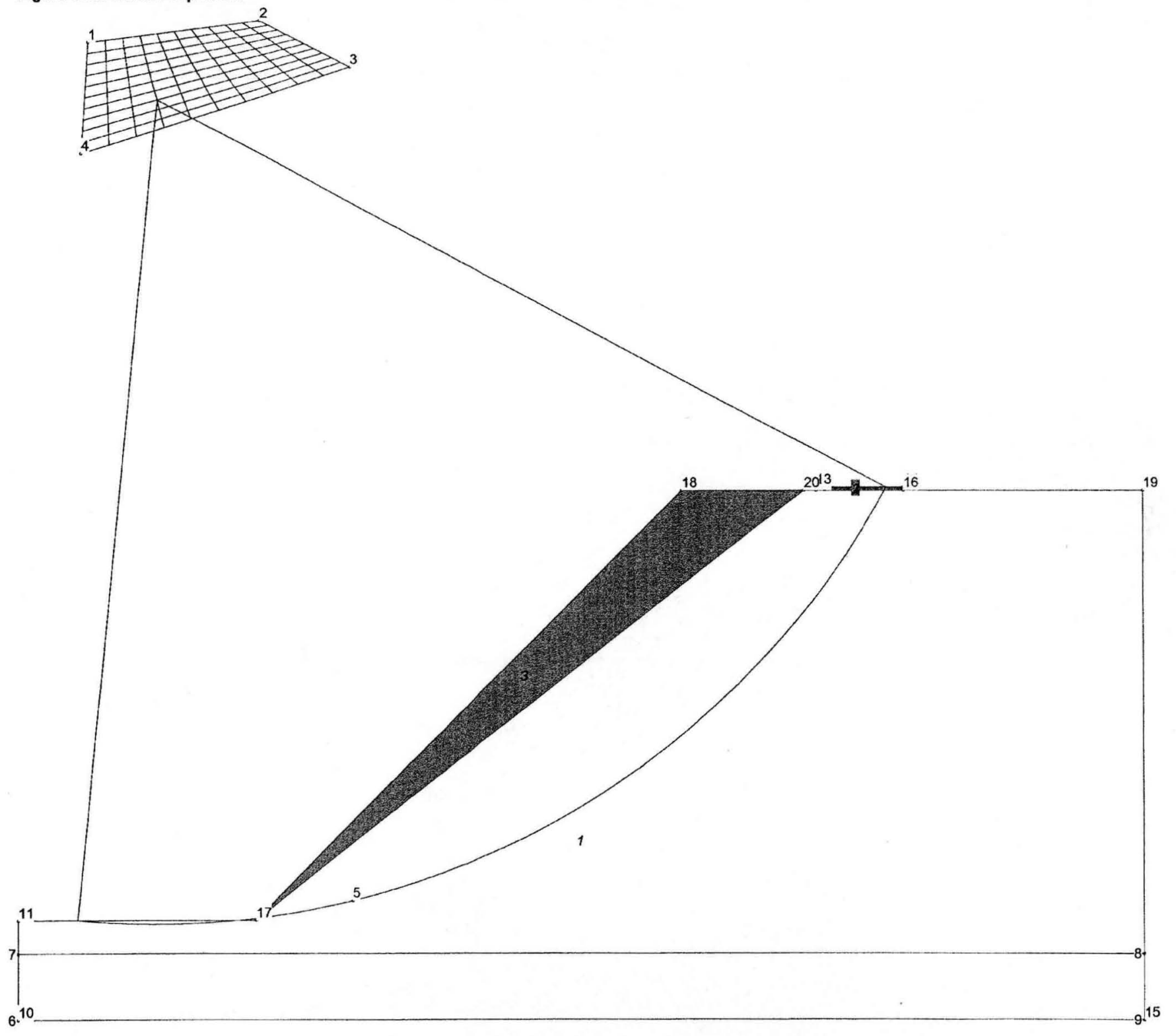

$F=1.088$ 
STB2006 - Slope Stability

David S. Messinger, P.E., Load Case 5A

Input Data

Coordinates of Nodes

$\begin{array}{ccc}\text { Node } & x & y \\ 1 & 2.111 & 29.560 \\ 2 & 7.127 & 30.226 \\ 3 & 9.935 & 28.822 \\ 4 & 1.905 & 26.189 \\ 5 & 10.000 & 3.600 \\ 6 & 0.000 & 0.000 \\ 7 & 0.000 & 2.000 \\ 8 & 34.000 & 2.000 \\ 9 & 34.000 & 0.000 \\ 10 & 0.000 & 0.000 \\ 11 & 0.000 & 3.000 \\ 12 & 24.000 & 16.000 \\ 13 & 24.000 & 16.100 \\ 14 & 26.625 & 16.100 \\ 15 & 34.000 & 0.000 \\ 16 & 26.625 & 16.000 \\ 17 & 7.000 & 3.000 \\ 18 & 20.000 & 16.000 \\ 19 & 34.000 & 16.000 \\ 20 & 23.639 & 16.000\end{array}$

\section{Structure of Polygons}

Window of centers of slip circles

Nodes 1

Fixed point of all slip circles

$$
\text { Node } 5
$$

Water Polygon

$\begin{array}{lllll}\text { Nodes } & 6 & 7 & 8 & 9\end{array}$

Soil Polygons

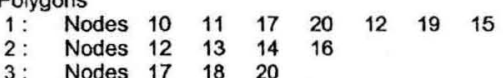

Properties of Soils

$\begin{array}{ccccccccc}\text { Soil } & \begin{array}{c}W d \\ \mathrm{kN} / \mathrm{m}^{3}\end{array} & \begin{array}{c}W \mathrm{~s} \\ \mathrm{kN} / \mathrm{m}^{3}\end{array} & \begin{array}{c}\mathrm{Ko} \\ \end{array} & \begin{array}{c}\mathrm{c} \\ \mathrm{kN} / \mathrm{m}^{2}\end{array} & \begin{array}{c}\mathrm{phi} \\ \text { degrees }\end{array} & \mathrm{P} / \mathrm{F} & \begin{array}{c}\mathrm{p}=0 \\ \mathrm{~m}\end{array} & \begin{array}{c}\text { cap } \\ \mathrm{m}\end{array} \\ 1 & 110.000 & 110.000 & 1.000 & 0.000 & 38.000 & \mathrm{P} & & 0.000 \\ 2 & 12571.430 & 12571.430 & 1.000 & 0.000 & 0.000 & \mathrm{P} & & 0.000 \\ 3 & 110.000 & 110.000 & 1.000 & 0.000 & 38.000 & \mathrm{P} & & 0.000\end{array}$

Output Data

Safety Factors

\begin{tabular}{|c|c|c|c|c|c|c|c|c|c|c|}
\hline 1.410 & 1.432 & 1.453 & 1.476 & 1.500 & 1.524 & 1.548 & 1.573 & 1.600 & 1.628 & 1.654 \\
\hline 1.360 & 1.376 & 1.393 & 1.410 & 1.427 & 1.446 & 1.465 & 1.485 & 1.504 & 1.524 & 1.547 \\
\hline 1.312 & 1.322 & 1.335 & 1.348 & 1.359 & 1.372 & 1.385 & 1.400 & 1.414 & 1.429 & 1.443 \\
\hline 1.264 & 1.272 & 1.281 & 1.288 & 1.296 & 1.304 & 1.312 & 1.320 & 1.330 & 1.339 & 1.348 \\
\hline 1.221 & 1.223 & 1.228 & 1.230 & 1.235 & 1.238 & 1.241 & 1.247 & 1.250 & 1.255 & 1.258 \\
\hline 1.178 & 1.178 & 1.178 & 1.177 & 1.177 & 1.176 & 1.177 & 1.176 & 1.176 & 1.176 & 1.176 \\
\hline 1.139 & 1.135 & 1.131 & 1.126 & 1.124 & 1.119 & 1.115 & 1.111 & 1.104 & 1.103 & 1.105 \\
\hline 1.111 & 1.103 & 1.091 & 1.090 & 1.089 & 1.089 & 1.089 & 1.088 & 1.089 & 1.089 & 1.091 \\
\hline 1.097 & 1.096 & 1.096 & 1.097 & 1.096 & 1.097 & 1.099 & 1.103 & 1.106 & 1.109 & 1.121 \\
\hline 1.104 & 1.106 & 1.108 & 1.112 & 1.116 & 1.120 & 1.128 & 1.135 & 1.146 & 1.157 & 1.178 \\
\hline 1.114 & 1.121 & 1.127 & 1.134 & 1.145 & 1.158 & 1.170 & 1.190 & 1.210 & 1.226 & 1.222 \\
\hline
\end{tabular}

Critical slip circle

Center: $x=4.104, y=27.813$, Radius: $24.921, F=1.088$
APPENDIX A

CALC. NO. 122633-C-004 
STB2006 - Slope Stability

Copyright $\odot 2006$ by A. Verruijt
APPENDIX A

CALC. NO. 122633-C-004
Appendix Page 26 of 43
Page 1

David S. Messinger, P.E., Load Case 5B

\section{General Data}

$\begin{array}{ll}\text { Licensed User } & \text { : David S. Messinger, P.E. } \\ \text { File Name } & \text { : CWC05B.stb }\end{array}$

Problem Name

Number of Slices

: Load Case 5B

Relative Horizontal Force: $\quad 0.000000$

Number of Nodes

Number of Soil Polygons : 3

Figure with critical slip circle

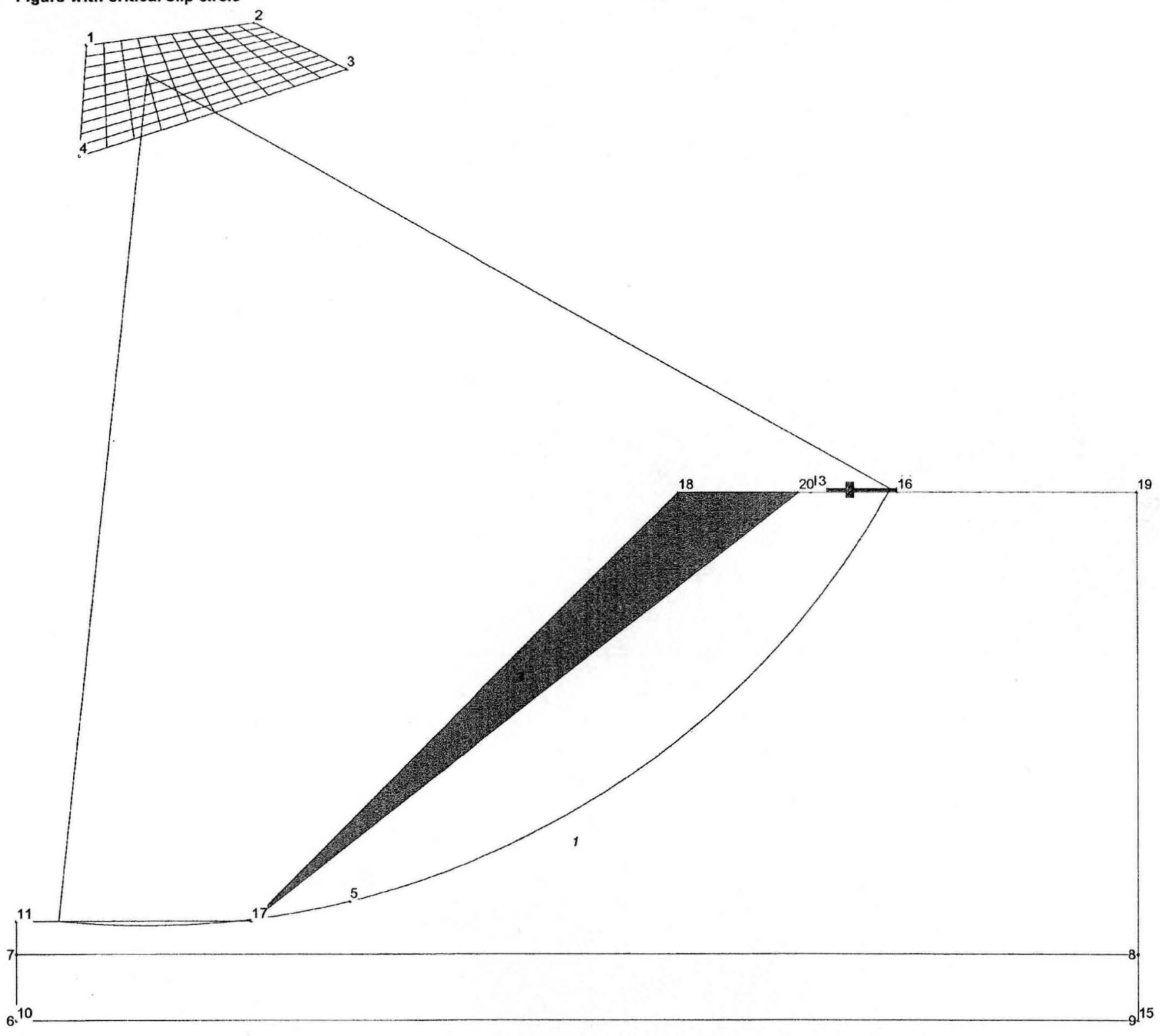

$F=1.022$ 
STB2006 - Slope Stability

David S. Messinger, P.E., Load Case 5B

Input Data

Coordinates of Nodes

$\begin{array}{ccc}\text { Node } & x & y \\ 1 & 2.111 & 29.560 \\ 2 & 7.127 & 30.226 \\ 3 & 9.935 & 28.822 \\ 4 & 1.905 & 26.189 \\ 5 & 10.000 & 3.600 \\ 6 & 0.000 & 0.000 \\ 7 & 0.000 & 2.000 \\ 8 & 34.000 & 2.000 \\ 9 & 34.000 & 0.000 \\ 10 & 0.000 & 0.000 \\ 11 & 0.000 & 3.000 \\ 12 & 24.000 & 16.000 \\ 13 & 24.000 & 16.100 \\ 14 & 26.625 & 16.100 \\ 15 & 34.000 & 0.000 \\ 16 & 26.625 & 16.000 \\ 17 & 7.000 & 3.000 \\ 18 & 20.000 & 16.000 \\ 19 & 34.000 & 16.000 \\ 20 & 23.639 & 16.000\end{array}$

\section{Structure of Polygons}

Window of centers of slip circles Nodes $\begin{array}{llll}1 & 2 & 3 & 4\end{array}$

Fixed point of all slip circles Node 5

Water Polygon

Soil Polygons Nodes $\begin{array}{llll}6 & 7 & 8\end{array}$

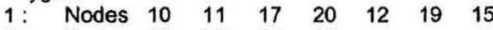

2: $\quad$ Nodes $12 \quad 13 \quad 14 \quad 16$

3: Nodes $\begin{array}{lll}17 & 18 & 20\end{array}$

Properties of Solls

$\begin{array}{ccccccccc}\text { Soil } & \begin{array}{c}\text { Wd } \\ \mathrm{kN} / \mathrm{m}^{3}\end{array} & \begin{array}{c}\mathrm{Ws} \\ \mathrm{kN} / \mathrm{m}^{3}\end{array} & \begin{array}{c}\mathrm{Ko} \\ \end{array} & \begin{array}{c}\mathrm{C} \\ \mathrm{kN} / \mathrm{m}^{2}\end{array} & \begin{array}{c}\text { phi } \\ \text { degrees }\end{array} & \mathrm{P} / \mathrm{F} & \begin{array}{c}\mathrm{p}=0 \\ \mathrm{~m}\end{array} & \begin{array}{c}\text { cap } \\ \mathrm{m}\end{array} \\ 1 & 110.000 & 110.000 & 1.000 & 0.000 & 38.000 & \mathrm{P} & & 0.000 \\ 2 & 12571.430 & 12571.430 & 1.000 & 0.000 & 0.000 & \mathrm{P} & & 0.000 \\ 3 & 0.000 & 10.000 & 1.000 & 0.000 & 0.000 & \mathrm{P} & & 0.000\end{array}$

Output Data

Safety Factors

$\begin{array}{lllllllllll}1.320 & 1.341 & 1.360 & 1.380 & 1.402 & 1.424 & 1.445 & 1.468 & 1.492 & 1.517 & 1.541 \\ 1.275 & 1.289 & 1.304 & 1.319 & 1.334 & 1.351 & 1.368 & 1.387 & 1.404 & 1.421 & 1.442 \\ 1.230 & 1.239 & 1.250 & 1.262 & 1.271 & 1.283 & 1.295 & 1.308 & 1.320 & 1.334 & 1.347 \\ 1.185 & 1.192 & 1.199 & 1.206 & 1.213 & 1.220 & 1.227 & 1.234 & 1.243 & 1.250 & 1.258 \\ 1.145 & 1.146 & 1.150 & 1.152 & 1.156 & 1.158 & 1.161 & 1.165 & 1.168 & 1.172 & 1.175 \\ 1.104 & 1.104 & 1.103 & 1.102 & 1.101 & 1.101 & 1.100 & 1.099 & 1.099 & 1.098 & 1.098 \\ 1.068 & 1.064 & 1.060 & 1.054 & 1.051 & 1.047 & 1.042 & 1.038 & 1.030 & 1.029 & 1.031 \\ 1.045 & 1.037 & 1.023 & 1.022 & 1.022 & 1.023 & 1.023 & 1.023 & 1.025 & 1.027 & 1.030 \\ 1.038 & 1.038 & 1.040 & 1.042 & 1.043 & 1.047 & 1.052 & 1.059 & 1.066 & 1.073 & 1.094 \\ 1.055 & 1.061 & 1.067 & 1.075 & 1.085 & 1.097 & 1.113 & 1.129 & 1.151 & 1.177 & 1.218 \\ 1.080 & 1.094 & 1.108 & 1.124 & 1.148 & 1.175 & 1.205 & 1.249 & 1.298 & 1.342 & 1.353\end{array}$

Critical slip circle

Center: $x=3.895, y=28.648$, Radlus: $25.781, F=1.022$ 
STB2006 - Slope Stability Copyright $(\odot 2006$ by A. Verruijt
APPENDIX A

CALC. NO. 122633-C-004
Appendix Page 28 of 43

Page 1

David S. Messinger, P.E., Load Case 6A

General Data

$$
\begin{array}{ll}
\text { Licensed User } & : \text { David S. Messinger, P.E. } \\
\text { File Name } & : \text { CWCO6A.stb } \\
\text { Problem Name } & : \text { Load Case 6A } \\
\text { Number of Slices } & : 1000 \\
\text { Relative Horizontal Force: } 0.000000 & : 20 \\
\text { Number of Nodes } & : 20 \\
\text { Number of Soil Polygons }: 3
\end{array}
$$

Figure with critical slip clrcle

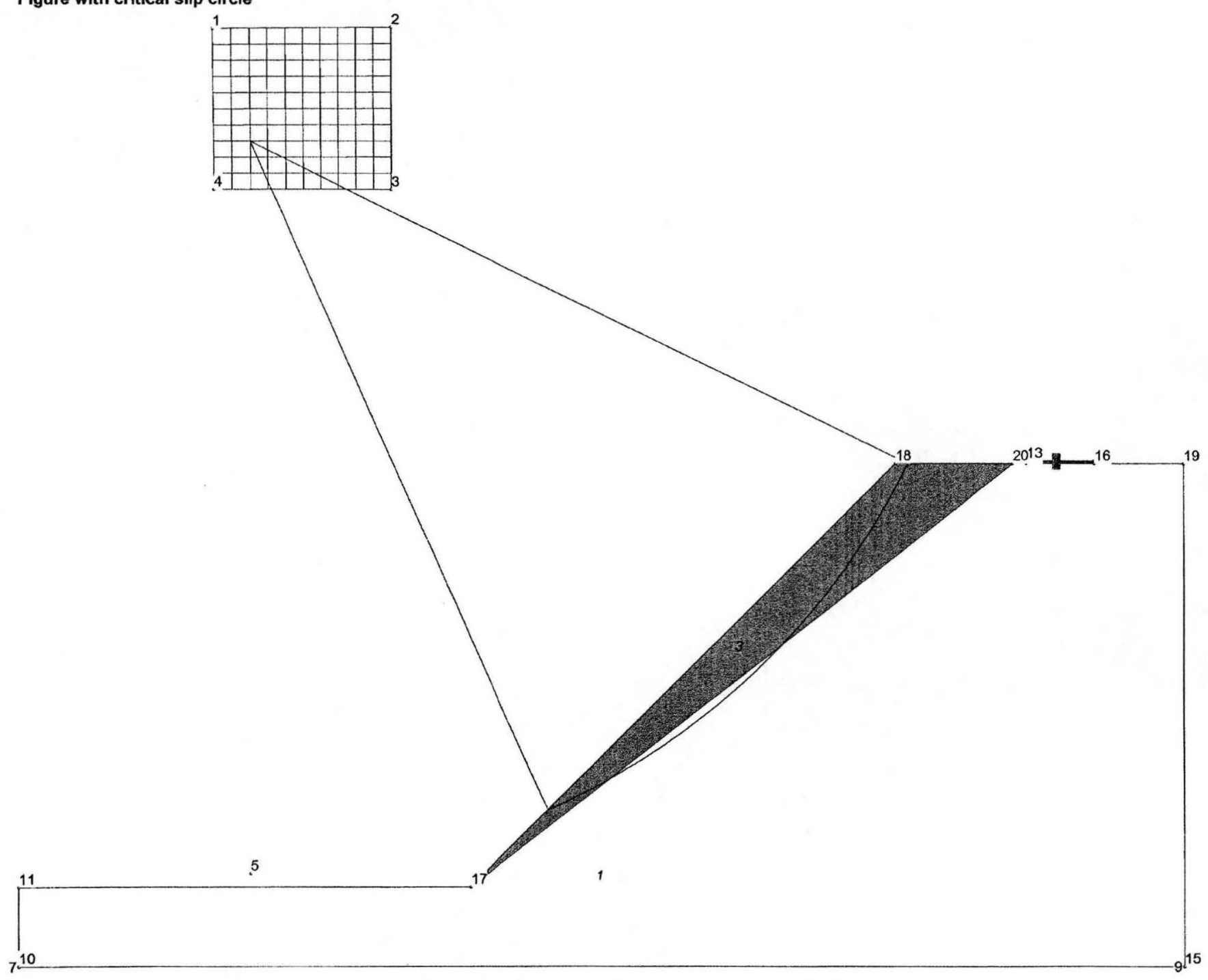

$$
F=1.000
$$

Input Data

\section{Coordinates of Nodes}

$\begin{array}{ccc}\text { Node } & x & y \\ 1 & 7.192 & 35.486 \\ 2 & 14.013 & 35.541 \\ 3 & 14.013 & 29.385 \\ 4 & 7.247 & 29.385 \\ 5 & & 3.500 \\ 6 & 0.000 & 0.000 \\ 7 & 0.000 & 0.000 \\ 8 & 44.000 & 0.000 \\ 9 & 44.000 & 0.000\end{array}$


STB2006 - Slope Stability

David S. Messinger, P.E., Load Case 6A

\section{APPENDIX A}

CALC. NO. 122633-C-004
Appendix Page 29 of 43

$\begin{array}{lcc}10 & 0.000 & 0.000 \\ 11 & 0.000 & 3.000 \\ 12 & 38.000 & 19.000 \\ 13 & 38.000 & 19.100 \\ 14 & 40.625 & 19.100 \\ 15 & 44.000 & 0.000 \\ 16 & 40.625 & 19.000 \\ 17 & 17.000 & 3.000 \\ 18 & 33.000 & 19.000 \\ 19 & 44.000 & 19.000 \\ 20 & 37.479 & 19.000\end{array}$

\section{Structure of Polygons}

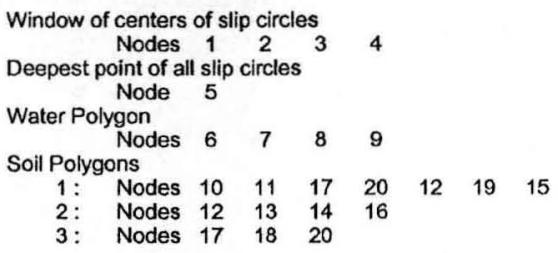

Properties of Soils

$\begin{array}{ccccccccc}\text { Soil } & \begin{array}{c}\mathrm{Wd} \\ \mathrm{kN} / \mathrm{m}^{3}\end{array} & \begin{array}{c}\mathrm{Ws} \\ \mathrm{kN} / \mathrm{m}^{3}\end{array} & \begin{array}{c}\mathrm{Ko} \\ \end{array} & \begin{array}{c}c \\ \mathrm{kN} / \mathrm{m}^{2}\end{array} & \begin{array}{c}\mathrm{phl} \\ \text { degrees }\end{array} & \begin{array}{l}\mathrm{P} / \mathrm{F} \\ \mathrm{p}=0\end{array} & \begin{array}{c}\text { cap } \\ \mathrm{m}\end{array} \\ 1 & 110.000 & 110.000 & 1.000 & 12.300 & 38.000 & \mathrm{P} & & 0.000 \\ 2 & 12571.430 & 12571.430 & 1.000 & 0.000 & 0.000 & \mathrm{P} & & 0.000 \\ 3 & 110.000 & 110.000 & 1.000 & 12.300 & 38.000 & \mathrm{P} & & 0.000\end{array}$

\section{Output Data}

\section{Safety Factors}

\begin{tabular}{|c|c|c|c|c|c|c|c|c|c|c|}
\hline 1.215 & 1.193 & 1.171 & 1.156 & 1.155 & 1.158 & 1.163 & 1.172 & 1.183 & 1.201 & 1.205 \\
\hline 1.164 & 1.147 & 1.146 & 1.147 & 1.151 & 1.157 & 1.168 & 1.183 & 1.196 & 1.179 & 1.162 \\
\hline 1.138 & 1.138 & 1.140 & 1.146 & 1.155 & 1.168 & 1.189 & 1.172 & 1.155 & 1.138 & 1.122 \\
\hline 1.133 & 1.138 & 1.146 & 1.158 & 1.179 & 1.165 & 1.148 & 1.131 & 1.115 & 1.100 & 1.085 \\
\hline 1.138 & 1.149 & 1.166 & 1.159 & 1.142 & 1.126 & 1.110 & 1.094 & 1.079 & 1.064 & 1.051 \\
\hline 1.154 & 1.154 & 1.138 & 1.121 & 1.105 & 1.089 & 1.074 & 1.059 & 1.046 & 1.034 & 1.023 \\
\hline 1.133 & 1.117 & 1.101 & 1.085 & 1.070 & 1.055 & 1.042 & 1.029 & 1.019 & 1.010 & 1.005 \\
\hline 1.098 & 1.082 & 1.067 & 1.052 & 1.039 & 1.027 & 1.016 & 1.007 & 1.002 & 1.001 & 1.006 \\
\hline 1.065 & 1.050 & 1.037 & 1.024 & 1.014 & 1.005 & 1.000 & 1.000 & 1.006 & 1.017 & 1.032 \\
\hline 1.03 & 1.024 & 1.013 & 1.005 & 1.000 & 1.000 & 1.008 & 1.024 & 1.043 & 1.073 & 1.117 \\
\hline 01 & 1.006 & 1.002 & 1.004 & 1.014 & 1.034 & 1.061 & 1.101 & 1.165 & 1.278 & 1.517 \\
\hline
\end{tabular}

Critical slip circle

Center: $x=8.587, y=31.219$, Radius: $27.719, F=1.000$ 
STB2006 - Slope Stability

Copyright $@ 2006$ by A. Verruijt

David S. Messinger, P.E., Load Case 6B

General Data

$\begin{array}{ll}\text { Licensed User } & \text { : David S. Messinger, P.E } \\ \text { File Name } & : \text { CWC06B.stb } \\ \text { Problem Name } & : \text { Load Case 6B } \\ \text { Number of Slices } & 1000 \\ \text { Relative Horizontal Force: } & 0.000000 \\ \text { Number of Nodes } & 20 \\ \text { Number of Soil Polygons } & 3\end{array}$

Definition Figure
APPENDIX A

CALC. NO. 122633-C-004

\section{Appendix Page 30 of 43}

Page 1

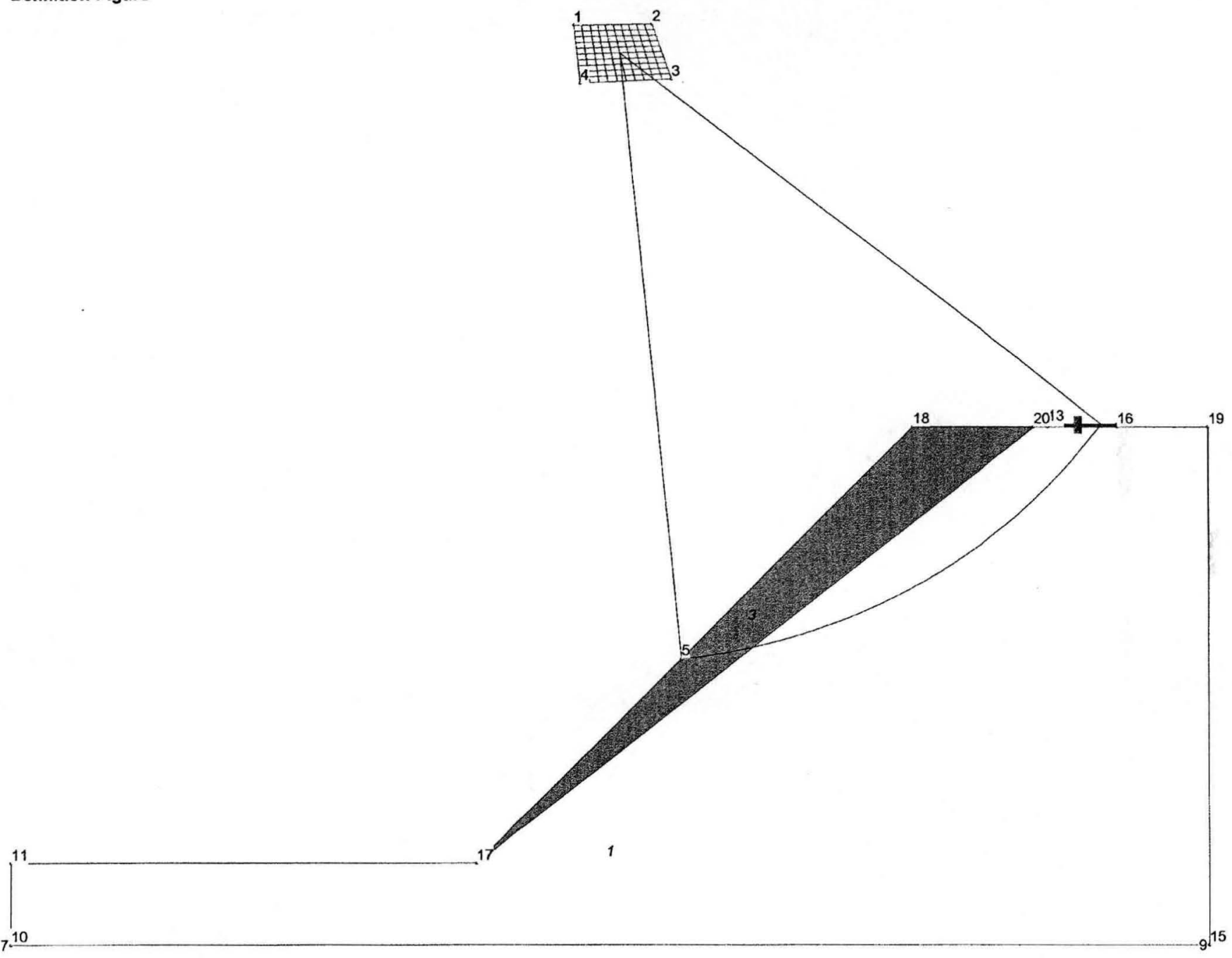

Input Data

Coordinates of Nodes

$\begin{array}{ccc}\text { Node } & x & y \\ 1 & 20.630 & 33.790 \\ 2 & 23.479 & 33.845 \\ 3 & 24.191 & 31.818 \\ 4 & 20.850 & 31.653 \\ 5 & 24.500 & 10.500 \\ 6 & 0.000 & 0.000 \\ 7 & 0.000 & 0.000 \\ 8 & 44.000 & 0.000 \\ 9 & 44.000 & 0.000 \\ 10 & 0.000 & 0.000 \\ 11 & 0.000 & 3.000 \\ 12 & 38.000 & 19.000 \\ 13 & 38.000 & 19.100 \\ 14 & 40.625 & 19.100 \\ 15 & 44.000 & 0.000\end{array}$


STB2006 - Slope Stability

David S. Messinger, P.E., Load Case 6B

$\begin{array}{lll}16 & 40.625 & 19.000 \\ 17 & 17.000 & 3.000 \\ 18 & 33.000 & 19.000 \\ 19 & 44.000 & 19.000 \\ 20 & 37.479 & 19.000\end{array}$

Structure of Polygons

Nodes 1
Fixed point of all slip circles

$$
\text { Node } 5
$$

Water Polygon

$$
\begin{aligned}
& \text { ygon } \\
& \text { Node } \\
& \text { Nons }
\end{aligned}
$$

$\begin{array}{llllll}\text { Soil Polygons } & 6 & 7 & 8 & 9\end{array}$

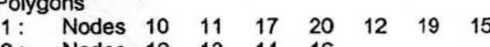

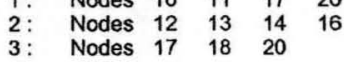

Properties of Soils

$\begin{array}{ccccccccc}\text { Soil } & \begin{array}{c}W d \\ \mathrm{kN} / \mathrm{m}^{3}\end{array} & \begin{array}{c}W \mathrm{~W} \\ \mathrm{kN} / \mathrm{m}^{3}\end{array} & \begin{array}{c}\mathrm{Ko} \\ \end{array} & \begin{array}{c}\mathrm{c} \\ \mathrm{kN} / \mathrm{m}^{2}\end{array} & \begin{array}{c}\text { phi } \\ \text { degrees }\end{array} & \mathrm{P} / \mathrm{F} & \begin{array}{c}\mathrm{p}=0 \\ \mathrm{~m}\end{array} & \begin{array}{c}\text { cap } \\ \mathrm{m}\end{array} \\ 1 & 110.000 & 110.000 & 1.000 & 12.300 & 38.000 & \mathrm{P} & & 0.000 \\ 2 & 12571.430 & 12571.430 & 1.000 & 0.000 & 0.000 & \mathrm{P} & & 0.000 \\ 3 & 0.000 & 10.000 & 1.000 & 0.000 & 0.000 & \mathrm{P} & & 0.000\end{array}$

\section{Output Data}

\section{Safety Factors}

$\begin{array}{lllllllllll}1.185 & 1.182 & 1.177 & 1.173 & 1.169 & 1.164 & 1.161 & 1.156 & 1.151 & 1.146 & 1.143 \\ 1.149 & 1.144 & 1.139 & 1.134 & 1.129 & 1.124 & 1.119 & 1.113 & 1.106 & 1.101 & 1.097 \\ 1.115 & 1.108 & 1.102 & 1.095 & 1.090 & 1.082 & 1.077 & 1.071 & 1.064 & 1.053 & 1.042 \\ 1.079 & 1.072 & 1.065 & 1.047 & 1.044 & 1.041 & 1.039 & 1.036 & 1.033 & 1.031 & 1.029 \\ 1.039 & 1.036 & 1.033 & 1.035 & 1.033 & 1.030 & 1.027 & 1.024 & 1.022 & 1.020 & \mathbf{1 . 0 1 8} \\ 1.028 & 1.025 & 1.022 & 1.018 & 1.016 & 1.013 & 1.017 & 1.016 & 1.013 & 1.012 & \mathbf{1 . 0 1 1} \\ 1.018 & 1.016 & 1.013 & 1.010 & 1.008 & 1.006 & 1.003 & 1.002 & 1.001 & 1.008 & 1.007 \\ 1.011 & 1.008 & 1.006 & 1.004 & 1.003 & 1.001 & 1.002 & 1.001 & 1.002 & 1.002 & 1.005 \\ 1.006 & 1.004 & 1.003 & 1.002 & 1.002 & 1.003 & 1.003 & 1.005 & 1.008 & 1.013 & 1.017 \\ 1.004 & 1.004 & 1.005 & 1.006 & 1.008 & 1.011 & 1.014 & 1.022 & 1.029 & 1.040 & 1.050 \\ 1.006 & 1.009 & 1.011 & 1.015 & 1.021 & 1.031 & 1.038 & 1.052 & 1.069 & 1.090 & 1.117\end{array}$

Critical slip circle

APPENDIX A

CALC. NO. 122633-C-004
Appendix Page 31 of 43

Page 2

Center: $x=21.742, y=32.334$, Radius: $22.386, F=1.001$ 
David S. Messinger, P.E., Load Case 6C

General Data

Licensed User

File Name

Problem Name

Number of Slices

Relative Horizontal
Number of Nodes

: David S. Messinger, P.E.

: CWC06C.stb

Load Case 6C

Number of Soil Polygons : 2

Figure with critical slip circle

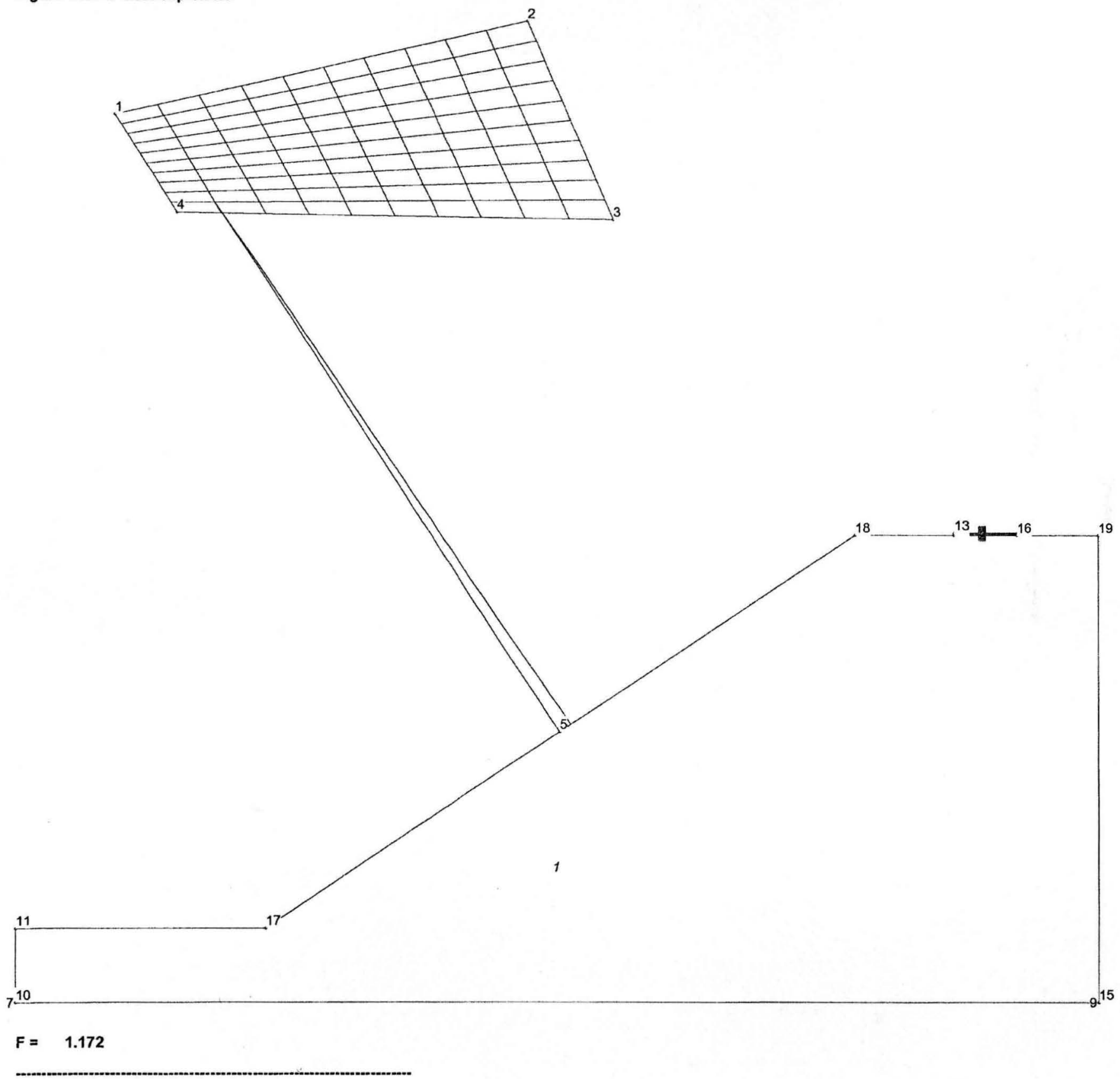


STB2006 - Slope Stability

David S. Messinger, P.E., Load Case 6C

Input Data

Coordinates of Nodes

$\begin{array}{ccc}\text { Node } & x & y \\ 1 & 4.013 & 36.115 \\ 2 & 20.767 & 39.931 \\ 3 & 24.191 & 31.818 \\ 4 & 6.469 & 32.117 \\ 5 & 22.000 & 11.000 \\ 6 & 0.000 & 0.000 \\ 7 & 0.000 & 0.000 \\ 8 & 44.000 & 0.000 \\ 9 & 44.000 & 0.000 \\ 10 & 0.000 & 0.000 \\ 11 & 0.000 & 3.000 \\ 12 & 38.000 & 19.000 \\ 13 & 38.000 & 19.100 \\ 14 & 40.625 & 19.100 \\ 15 & 44.000 & 0.000 \\ 16 & 40.625 & 19.000 \\ 17 & 10.000 & 3.000 \\ 18 & 34.000 & 19.000 \\ 19 & 44.000 & 19.000\end{array}$

Structure of Polygons

Window of centers of slip circles Nodes $\begin{array}{llll}1 & 2 & 3 & 4\end{array}$

Fixed point of all slip circles Node 5

Water Polygon

Nodes $\begin{array}{lllll}6 & 7 & 8 & 9\end{array}$

Soil Polygons

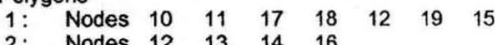

Properties of Solis

\begin{tabular}{|c|c|c|c|c|c|c|c|c|}
\hline Soil & $\begin{array}{l}\text { Wd } \\
\mathrm{kN} / \mathrm{m}^{3}\end{array}$ & $\begin{array}{l}\mathrm{Ws} \\
\mathrm{kN} / \mathrm{m}^{3}\end{array}$ & Ko & $\underset{\mathrm{kN} / \mathrm{m}^{2}}{\mathrm{C}}$ & $\begin{array}{c}\text { phi } \\
\text { degrees }\end{array}$ & P/F & $\begin{array}{c}p=0 \\
m\end{array}$ & $\begin{array}{l}\text { cap } \\
\mathrm{m}\end{array}$ \\
\hline 1 & 110.000 & 110.000 & 1.000 & 0.000 & 38.000 & $\mathrm{P}$ & & 0.000 \\
\hline 2 & 12571.430 & 12571.430 & 1.000 & 0.000 & 0.000 & $\mathrm{P}$ & & 0.000 \\
\hline
\end{tabular}

Output Data

Safety Factors

$\begin{array}{lllllllllll}1.466 & 1.463 & 1.462 & 1.461 & 1.461 & 1.462 & 1.465 & 1.465 & 1.468 & 1.473 & 1.478 \\ 1.412 & 1.415 & 1.416 & 1.420 & 1.422 & 1.427 & 1.433 & 1.437 & 1.452 & 1.462 & 1.473 \\ 1.519 & 1.518 & 1.518 & 1.518 & 1.518 & 1.519 & 1.520 & 1.522 & 1.524 & 1.526 & 1.530 \\ 1.378 & 1.376 & 1.374 & 1.372 & 1.371 & 1.369 & 1.368 & 1.367 & 1.367 & 1.367 & 1.368 \\ 1.268 & 1.267 & 1.265 & 1.263 & 1.262 & 1.261 & 1.261 & 1.261 & 1.261 & 1.262 & 1.263 \\ 1.213 & 1.214 & 1.215 & 1.216 & 1.217 & 1.218 & 1.220 & 1.221 & 1.222 & 1.224 & 1.225 \\ 1.196 & 1.196 & 1.196 & 1.197 & 1.197 & 1.198 & 1.198 & 1.199 & 1.199 & 1.200 & 1.201 \\ 1.183 & 1.183 & 1.183 & 1.183 & 1.184 & 1.184 & 1.184 & 1.184 & 1.184 & 1.184 & 1.184 \\ 1.175 & 1.175 & 1.175 & 1.175 & 1.175 & 1.175 & 1.175 & 1.175 & 1.175 & 1.175 & 1.175 \\ 1.172 & 1.172 & 1.172 & 1.172 & 1.172 & 1.172 & 1.172 & 1.172 & 1.172 & 1.172 & 1.172 \\ 1.173 & 1.173 & 1.173 & 1.173 & 1.173 & 1.173 & 1.173 & 1.173 & 1.173 & 1.173 & 1.173\end{array}$

Critical slip circle

Center: $x=7.986, y=32.528$, Radius: $25.688, F=1.172$
APPENDIX A
CALC. NO. 122633-C-004
Appendix Page 33 of 43

Page 2 
STB2006 - Slope Stability Copyright $\odot 2006$ by A. Verruijt
APPENDIX A

CALC. NO. 122633-C-004

\section{Appendix Page 34 of 43}

Page 1

David S. Messinger, P.E., Load Case 6C1

\section{General Data}

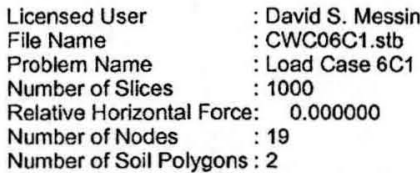

Licensed User

File Name

Problem Name

Number of Slices

: Load Case 6C1

Relative Horizontal Force: 0.000000

Number of Soil Polygons : 2

\section{Figure with critical slip circle}

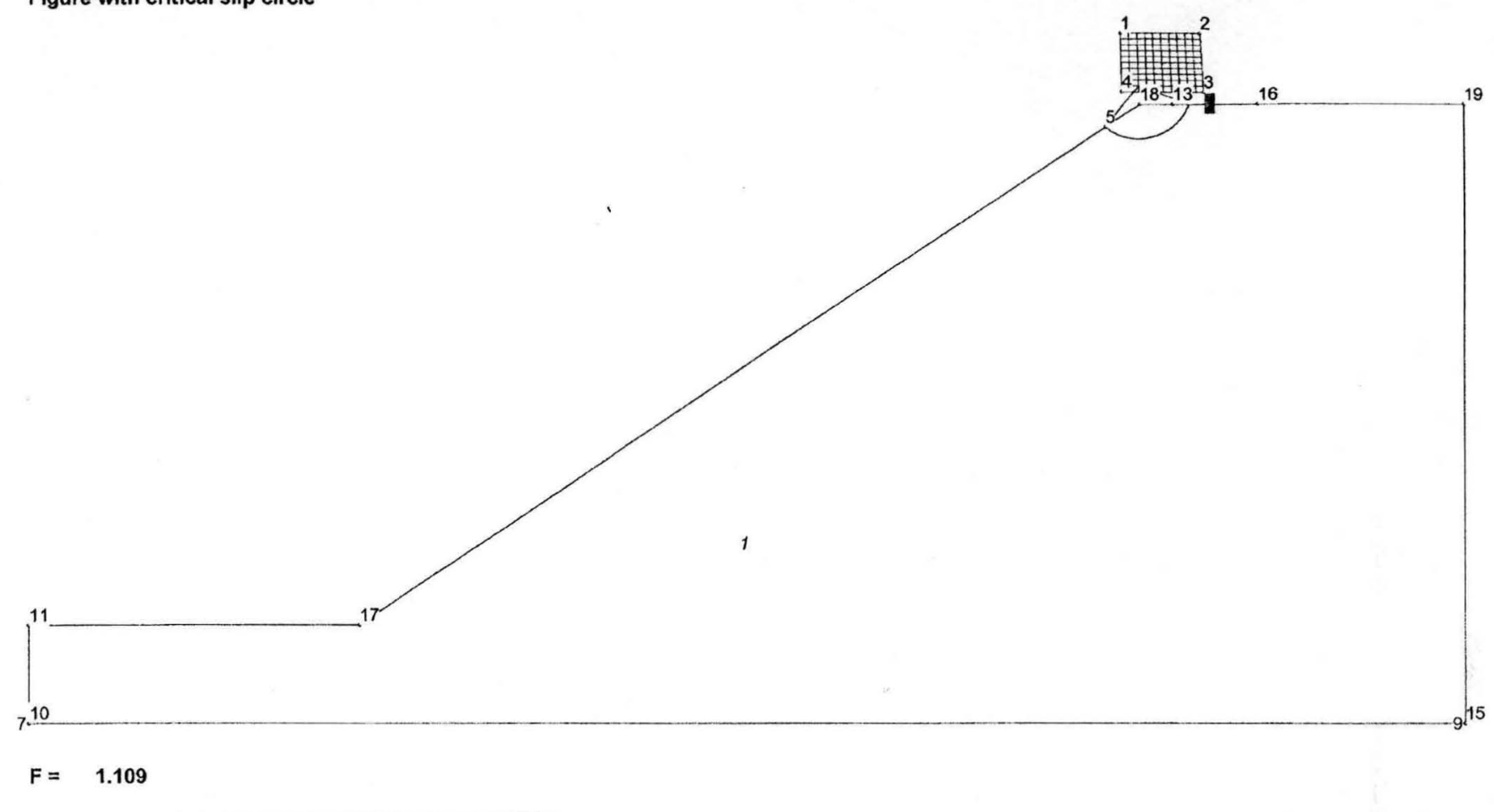

Input Data

\section{Coordinates of Nodes}

$\begin{array}{ccc}\text { Node } & x & y \\ 1 & 33.431 & 21.190 \\ 2 & 35.847 & 21.190 \\ 3 & 35.976 & 19.378 \\ 4 & 33.475 & 19.387 \\ 5 & 32.950 & 18.300 \\ 6 & 0.000 & 0.000 \\ 7 & 0.000 & 0.000 \\ 8 & 44.000 & 0.000 \\ 9 & 44.000 & 0.000 \\ 10 & 0.000 & 0.000 \\ 11 & 0.000 & 3.000 \\ 12 & 35.000 & 19.000 \\ 13 & 35.000 & 19.010 \\ 14 & 37.625 & 19.010 \\ 15 & 44.000 & 0.000 \\ 16 & 37.625 & 19.000 \\ 17 & 10.000 & 3.000 \\ 18 & 34.000 & 19.000 \\ 19 & 44.000 & 19.000\end{array}$

\section{Structure of Polygons}

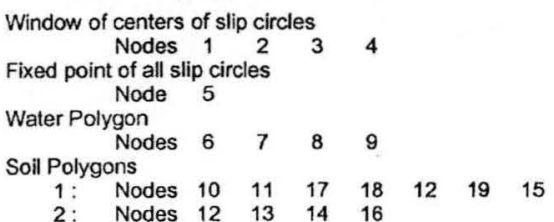


STB2006 - Slope Stability

David S. Messinger, P.E., Load Case 6C1

Properties of Soils

\begin{tabular}{|c|c|c|c|c|c|c|c|c|}
\hline Soil & $\begin{array}{l}\text { Wd } \\
\mathrm{kN} / \mathrm{m}^{3}\end{array}$ & $\begin{array}{l}\text { Ws } \\
\mathrm{kN} / \mathrm{m}^{3}\end{array}$ & Ko & $\underset{\mathrm{kN} / \mathrm{m}^{2}}{\mathrm{c}}$ & $\begin{array}{c}\text { phi } \\
\text { degrees }\end{array}$ & $\mathrm{P} / \mathrm{F}$ & $\begin{array}{l}p=0 \\
m\end{array}$ & $\underset{\mathrm{m}}{\text { cap }}$ \\
\hline 1 & 110.000 & 110.000 & 1.000 & 11.500 & 38.000 & P & & 0.000 \\
\hline 2 & 125714.300 & 125714.300 & 1.000 & 0.000 & 0.000 & $\mathrm{P}$ & & 0.000 \\
\hline
\end{tabular}

APPENDIX A

CALC. NO. 122633-C-004
Appendix Page 35 of 43

Page 2

Output Data

Safety Factors

$\begin{array}{lllllllllll}8.308 & \mathbf{8 . 3 3 9} & \mathbf{8 . 4 9 7} & 8.569 & \mathbf{8 . 7 2 9} & \mathbf{8 . 8 5 8} & 9.084 & 9.367 & 9.628 & 10.024 & 10.512 \\ 5.210 & \mathbf{5 . 1 6 4} & \mathbf{5 . 1 4 9} & \mathbf{5 . 1 4 4} & \mathbf{5 . 1 2 8} & 5.149 & 5.142 & 5.200 & 5.254 & 5.334 & 5.472 \\ 3.631 & 3.582 & 3.518 & 3.480 & 3.429 & 3.387 & 3.376 & 3.356 & 3.349 & 3.367 & 3.382 \\ 2.686 & 2.627 & 2.567 & 2.510 & 2.454 & 2.406 & 2.370 & 2.334 & 2.314 & 2.302 & 2.306 \\ 2.098 & \mathbf{2 . 0 5 9} & \mathbf{2 . 0 2 2} & 1.989 & 1.960 & 1.932 & 1.915 & 1.909 & 1.909 & 1.921 & 1.948 \\ 1.923 & \mathbf{1 . 8 8 3} & \mathbf{1 . 8 3 7} & 1.797 & 1.758 & 1.723 & 1.694 & 1.670 & 1.662 & 1.661 & 1.675 \\ 1.764 & \mathbf{1 . 7 1 4} & 1.664 & 1.619 & 1.573 & 1.530 & 1.493 & 1.460 & 1.434 & 1.426 & 1.427 \\ 1.621 & \mathbf{1 . 5 6 7} & 1.513 & 1.460 & 1.408 & 1.358 & 1.317 & 1.276 & 1.242 & 1.220 & 1.222 \\ 1.492 & \mathbf{1 . 4 3 6} & 1.380 & 1.331 & 1.278 & 1.227 & 1.179 & 1.138 & 1.117 & 1.109 & 1.137 \\ 1.393 & \mathbf{1 . 3 4 2} & 1.292 & 1.245 & 1.202 & 1.170 & 1.164 & 1.188 & 1.295 & 1.674 & 3.995 \\ 1.346 & \mathbf{1 . 3 1 8} & 1.306 & 1.326 & 1.427 & 1.866 & 3.691 & 3.602 & 3.522 & 3.458 & 3.421\end{array}$

Critical slip circle

Center: $x=33.969, y=19.566$, Radius: $1.625, F=1.109$ 
STB2006 - Slope Stability

Copyright (1) 2006 by A. Verruijt
APPENDIX A

CALC. NO. 122633-C-004
Appendix Page 36 of 43 .

Page 1

David S. Messinger, P.E., Load Case 6C2

General Data

Licensed User

File Name

Problem Name

Number of Slices

Relative Horizontal Force:

Number of Nodes

David S. Messinger, P.E.

: CWC06C2.stb

Load Case 6C2

Number of Soil Polygons : 2

0.000000

Definition Figure

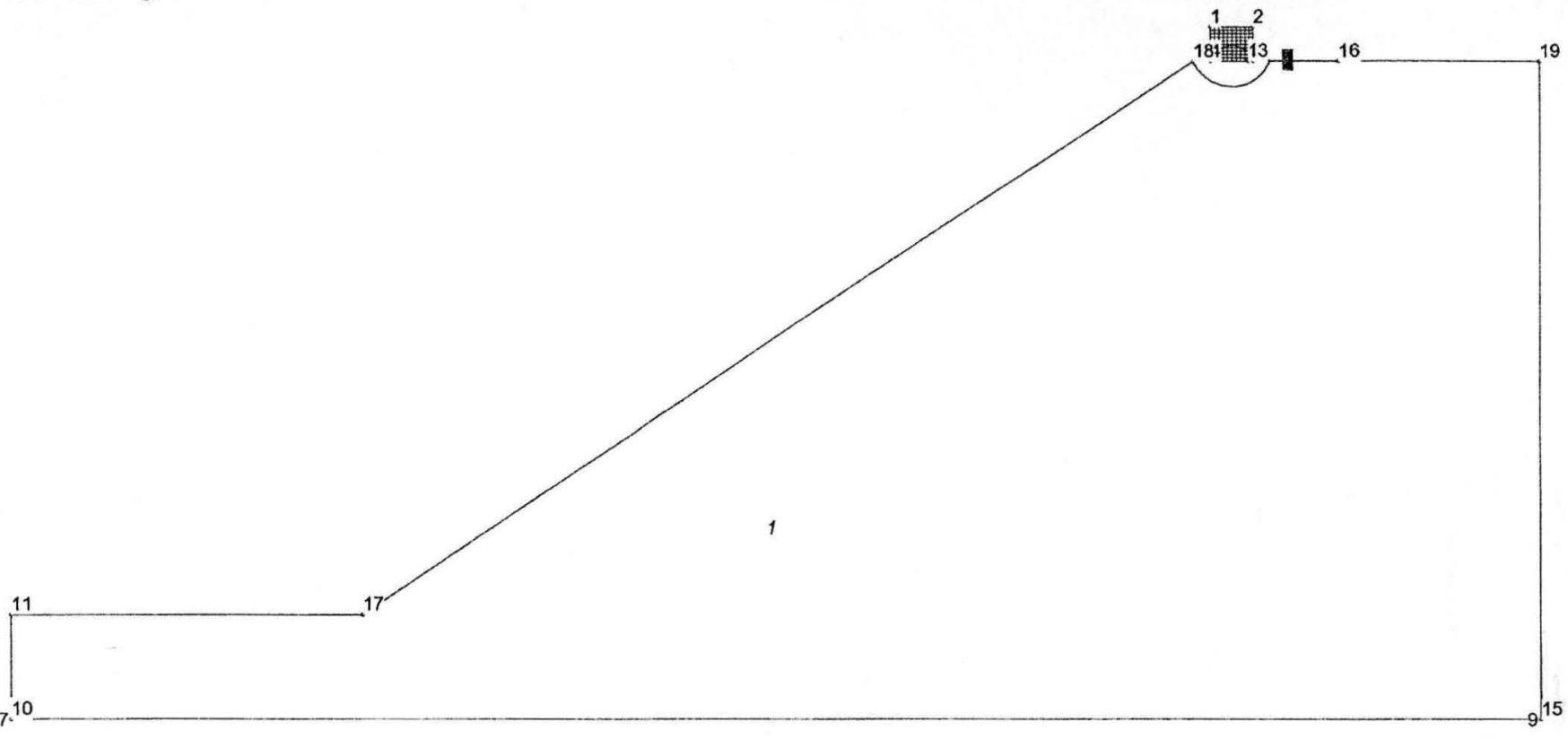

Input Data

Coordinates of Nodes

$\begin{array}{ccc}\text { Node } & \mathrm{x} & \mathrm{y} \\ 1 & 34.500 & 20.000 \\ 2 & 35.760 & 20.000 \\ 3 & 35.761 & 19.000 \\ 4 & 34.500 & 19.000 \\ 5 & 34.000 & 19.000 \\ 6 & 0.000 & 0.000 \\ 7 & 0.000 & 0.000 \\ 8 & 44.000 & 0.000 \\ 9 & 44.000 & 0.000 \\ 10 & 0.000 & 0.000 \\ 11 & 0.000 & 3.000 \\ 12 & 35.600 & 19.000 \\ 13 & 35.600 & 19.010 \\ 14 & 38.225 & 19.010 \\ 15 & 44.000 & 0.000 \\ 16 & 38.225 & 19.000 \\ 17 & 10.000 & 3.000 \\ 18 & 34.000 & 19.000 \\ 19 & 44.000 & 19.000\end{array}$

Structure of Polygons

Window of centers of slip circles Nodes 123

Fixed point of all slip circles

Node 5

Water Polygon

$\begin{array}{lllll}\text { Nodes } & 6 & 7 & 8 & 9\end{array}$

il Polygons

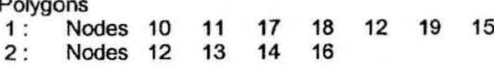


STB2006 - Slope Stability

David S. Messinger, P.E., Load Case 6C2

Properties of Soils

$\begin{array}{ccccccccc}\text { Soil } & \begin{array}{c}W d \\ \mathrm{kN} / \mathrm{m}^{3}\end{array} & \begin{array}{c}\mathrm{Ws} \\ \mathrm{kN} / \mathrm{m}^{3}\end{array} & \begin{array}{c}\mathrm{Ko} \\ \end{array} & \begin{array}{c}c \\ \mathrm{kN} / \mathrm{m}^{2}\end{array} & \begin{array}{c}\mathrm{phi} \\ \text { degrees }\end{array} & \begin{array}{c}\mathrm{P} / \mathrm{F} \\ \mathrm{p}=0\end{array} & \begin{array}{c}\text { cap } \\ \mathrm{m}\end{array} \\ 1 & 110.000 & 110.000 & 1.000 & 0.000 & 38.000 & \mathrm{P} & & 0.000 \\ 2 & 125714.300125714 .300 & 1.000 & 0.000 & 0.000 & \mathrm{P} & & 0.000\end{array}$

Appendix Page 37 of 43

Page 2

Output Data

Safety Factors

\begin{tabular}{|c|c|c|c|c|c|c|c|c|c|}
\hline 2.187 & 2.155 & 2.130 & 2.112 & 2.102 & 2.100 & 2.107 & 2.123 & 2.146 & 2.178 \\
\hline 2.027 & 1.991 & 1.961 & 1.937 & 1.922 & 1.916 & 1.919 & 1.932 & 1.954 & 1.983 \\
\hline 1.864 & 1.826 & 1.791 & 1.762 & 1.742 & 1.730 & 1.734 & 1.743 & 1.759 & 1.788 \\
\hline 1.715 & 1.666 & 1.624 & 1.595 & 1.569 & 1.552 & 1.542 & 1.554 & 1.571 & 1.600 \\
\hline 1.572 & 1.519 & 1.471 & 1.429 & 1.402 & 1.380 & 1.369 & 1.374 & 1.391 & 1.420 \\
\hline 1.445 & 1.383 & 1.327 & 1.285 & 1.244 & 1.221 & 1.206 & 1.205 & 1.227 & 1.260 \\
\hline 1.344 & 1.274 & 1.219 & 1.164 & 1.126 & 1.093 & 1.082 & 1.084 & 1.115 & 1.163 \\
\hline 1.341 & 1.287 & 1.224 & 1.189 & 1.164 & 1.145 & 1.164 & 1.222 & 1.298 & 1.453 \\
\hline- & - & -- & - & -- & $\ldots$ & -- & - & - & -.. \\
\hline-- & -- & -.. & -- & - & $\cdots$ & -.. & -.. & - & -- \\
\hline-- & -- & - & - & -- & - & -- & -.. & -- & -- \\
\hline
\end{tabular}

Critical slip circle

Center: $x=35.004, y=19.400$, Radius: $1.236, F=1.082$ 
STB2006 - Slope Stability

Copyright $\Theta 2006$ by A. Verruijt

David S. Messinger, P.E., Load Case 6C3

General Data

Licensed User

File Name

Problem Name

Number of Slices

Relative Horizontal

Number of Nodes
Number of Soil Polygons : 3

\section{Figure with critical slip circle}

David S. Messinger, P.E.

CWC06C3.stb

Load Case 6C3

1000

1

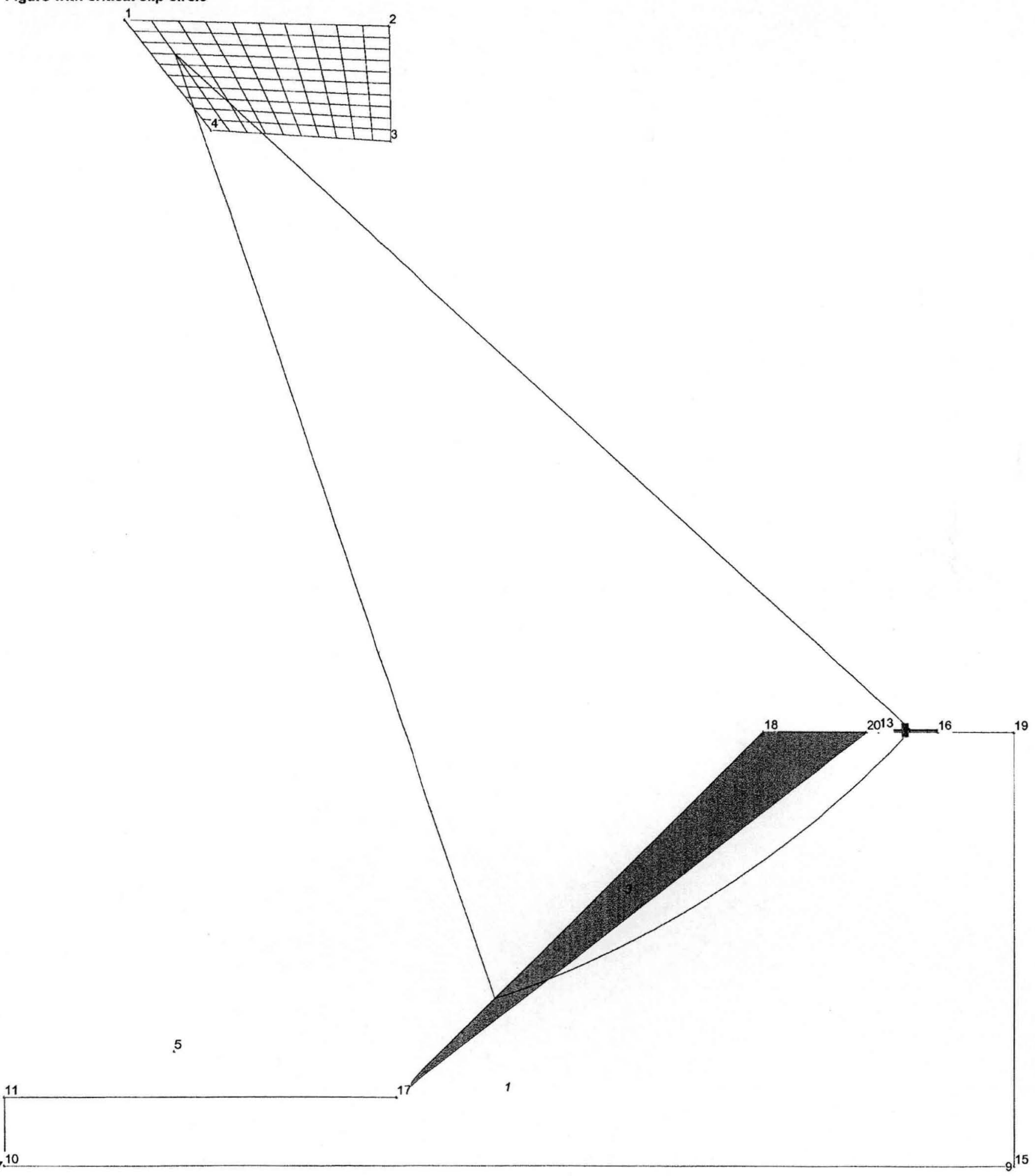

APPENDIX A

CALC. NO. 122633-C-004
Appendix Page 38 of 43

Page 1 
STB2006 - Slope Stability

David S. Messinger, P.E., Load Case 6C3

Input Data

Coordinates of Nodes

$\begin{array}{ccc}\text { Node } & x & y \\ 1 & 5.155 & 50.062 \\ 2 & 16.642 & 49.844 \\ 3 & 16.717 & 44.784 \\ 4 & 8.846 & 45.245 \\ 5 & & 5.000 \\ 6 & 0.000 & 0.000 \\ 7 & 0.000 & 0.000 \\ 8 & 44.000 & 0.000 \\ 9 & 44.000 & 0.000 \\ 10 & 0.000 & 0.000 \\ 11 & 0.000 & 3.000 \\ 12 & 38.000 & 19.000 \\ 13 & 38.000 & 19.100 \\ 14 & 40.625 & 19.100 \\ 15 & 44.000 & 0.000 \\ 16 & 40.625 & 19.000 \\ 17 & 17.000 & 3.000 \\ 18 & 33.000 & 19.000 \\ 19 & 44.000 & 19.000 \\ 20 & 37.479 & 19.000\end{array}$

\section{Structure of Polygons}

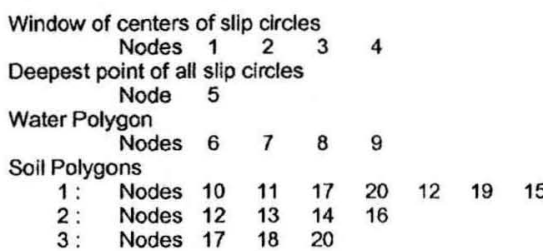

Properties of Soils

$\begin{array}{ccccccccc}\text { Soil } & \begin{array}{c}W d \\ \mathrm{kN} / \mathrm{m}^{3}\end{array} & \begin{array}{c}W \mathrm{Ws} \\ \mathrm{kN} / \mathrm{m}^{3}\end{array} & \begin{array}{c}\mathrm{Ko} \\ \end{array} & - & \begin{array}{c}\mathrm{C} \\ \mathrm{kN} / \mathrm{m}^{2}\end{array} & \begin{array}{c}\text { phi } \\ \text { degrees }\end{array} & \begin{array}{l}\mathrm{P} / \mathrm{F} \\ \mathrm{p}=0\end{array} & \begin{array}{c}\text { cap } \\ \mathrm{m}\end{array} \\ 1 & 110.000 & 110.000 & 1.000 & 11.500 & 38.000 & \mathrm{P} & & 0.000 \\ 2 & 12571.430 & 12571.430 & 1.000 & 0.000 & 0.000 & \mathrm{P} & & 0.000 \\ 3 & 0.000 & 10.000 & 1.000 & 0.000 & 38.000 & \mathrm{P} & & 0.000\end{array}$

Output Data

Safety Factors

$\begin{array}{lllllllllll}1.784 & 1.763 & 1.742 & 1.722 & 1.701 & 1.681 & 1.660 & 1.640 & \mathbf{1 . 6 2 0} & \mathbf{1 . 5 9 9} & 1.579 \\ 1.664 & 1.648 & \mathbf{1 . 6 3 2} & 1.616 & 1.600 & 1.584 & 1.568 & \mathbf{1 . 5 5 2} & \mathbf{1 . 5 3 6} & \mathbf{1 . 5 2 0} & 1.504 \\ 1.556 & 1.544 & \mathbf{1 . 5 3 2} & 1.521 & 1.509 & 1.497 & 1.485 & \mathbf{1 . 4 7 3} & \mathbf{1 . 4 6 1} & \mathbf{1 . 4 4 9} & 1.437 \\ 1.458 & 1.450 & \mathbf{1 . 4 4 2} & 1.434 & 1.425 & 1.417 & 1.407 & \mathbf{1 . 3 9 8} & \mathbf{1 . 3 9 0} & \mathbf{1 . 3 8 1} & 1.373 \\ 1.369 & 1.364 & \mathbf{1 . 3 5 9} & 1.353 & 1.348 & 1.341 & 1.336 & \mathbf{1 . 3 3 1} & \mathbf{1 . 3 2 6} & \mathbf{1 . 3 2 0} & 1.314 \\ 1.286 & 1.284 & 1.281 & 1.278 & 1.275 & 1.272 & \mathbf{1 . 2 6 9} & \mathbf{1 . 2 6 6} & \mathbf{1 . 2 6 3} & \mathbf{1 . 2 6 0} & 1.256 \\ 1.203 & 1.202 & 1.202 & 1.202 & 1.201 & 1.201 & \mathbf{1 . 2 0 0} & \mathbf{1 . 1 9 9} & \mathbf{1 . 1 9 9} & \mathbf{1 . 1 9 8} & 1.198 \\ 1.116 & 1.120 & 1.121 & 1.124 & 1.126 & 1.128 & \mathbf{1 . 1 3 0} & \mathbf{1 . 1 3 2} & \mathbf{1 . 1 3 4} & \mathbf{1 . 1 3 6} & 1.138 \\ 1.043 & 1.043 & 1.043 & 1.044 & 1.044 & 1.044 & \mathbf{1 . 0 4 5} & \mathbf{1 . 0 6 1} & \mathbf{1 . 0 6 7} & 1.072 & 1.077 \\ 1.038 & 1.033 & 1.030 & 1.026 & 1.033 & 1.031 & 1.030 & \mathbf{1 . 0 3 0} & \mathbf{1 . 0 3 1} & \mathbf{1 . 0 3 0} & 1.032 \\ 1.383 & 1.289 & 1.149 & 1.102 & 1.072 & 1.052 & \mathbf{1 . 0 4 0} & \mathbf{1 . 0 4 3} & \mathbf{1 . 0 3 5} & \mathbf{1 . 0 3 1} & \mathbf{1 . 0 2 8}\end{array}$

Critical slip circle

Center: $x=7.303, y=48.588$, Radius: $43.588, F=1.026$ 
STB2006 - Slope Stabllity

Copyright @ 2006 by A. Verruljt

David S. Messinger, P.E., Load Case 6D

General Data

Licensed User

File Name

Problem Name

Number of Slices

Relative Horizontal Force:

Number of Nodes
Number of Soil Polygons : 2

\section{Figure with critical slip circle}

David S. Messinger, P.E.

WC06D.stb

oad Case 6D

000

\section{APPENDIX A}

CALC. NO. 122633-C-004
Appendix Page 40 of 43

Page 1

$$
\left.\right|_{7} ^{11}
$$

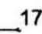

$F=1.057$

Input Data

Coordinates of Nodes

$\begin{array}{ccc}\text { Node } & x & y \\ 1 & 32.156 & 37.086 \\ 2 & 35.042 & 37.086 \\ 3 & 35.042 & 33.184 \\ 4 & 32.156 & 33.237 \\ 5 & 33.572 & 18.655 \\ 6 & 0.000 & 0.000\end{array}$


STB2006 - Slope Stability

David S. Messinger, P.E., Load Case 6D

\section{Structure of Polygons}

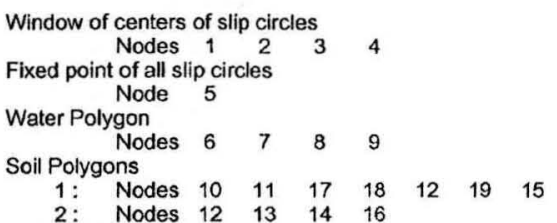

Properties of Soils

$\begin{array}{ccccccccc}\text { Soil } & \begin{array}{c}W d \\ \mathrm{kN} / \mathrm{m}^{3}\end{array} & \begin{array}{c}\mathrm{Ws} \\ \mathrm{kN} / \mathrm{m}^{3}\end{array} & \begin{array}{c}\mathrm{Ko} \\ \end{array} & \begin{array}{c}\mathrm{c} \\ \mathrm{kN} / \mathrm{m}^{2}\end{array} & \begin{array}{c}\text { phi } \\ \text { degrees }\end{array} & \begin{array}{c}\mathrm{P} / \mathrm{F} \\ \mathrm{p}=0\end{array} & \begin{array}{c}\text { cap } \\ \mathrm{m}\end{array} \\ 1 & 110.000 & 110.000 & 1.000 & 0.000 & 38.000 & \mathrm{P} & & 0.000 \\ 2 & 18214.290 & 18214.290 & 1.000 & 0.000 & 0.000 & \mathrm{P} & & 0.000\end{array}$

Output Data

Safety Factors

$\begin{array}{ccccccccccc}3.460 & 3.403 & 3.330 & 3.273 & 3.193 & 3.135 & 3.054 & 2.995 & 2.906 & 2.846 & 2.754 \\ 2.980 & 2.917 & 2.812 & 2.713 & 2.633 & 2.514 & 2.375 & 2.279 & 2.117 & 1.984 & 1.784 \\ 1.913 & 1.662 & 1.403 & 1.057 & 1.077 & 1.301 & 1.564 & 1.972 & 2.561 & 3.441 & 5.003 \\ 2.636 & 3.479 & 4.562 & 6.598 & 9.143 & 11.871 & 12.315 & 12.197 & \mathbf{1 2 . 0 7 7} & 11.956 & 11.833 \\ 11.499 & 11.386 & 11.272 & 11.156 & 11.039 & 10.920 & 10.801 & 10.679 & \mathbf{1 0 . 5 5 7} & 10.433 & 10.307 \\ 10.211 & 10.098 & 9.983 & 9.868 & 9.751 & 9.633 & 9.513 & 9.392 & 9.270 & 9.146 & 9.020 \\ 9.106 & 8.995 & 8.882 & 8.769 & 8.654 & 8.538 & 8.421 & 8.302 & 8.182 & 8.060 & 7.937 \\ 8.159 & 8.051 & 7.942 & 7.832 & 7.721 & 7.608 & 7.494 & 7.379 & 7.263 & 7.145 & 7.026 \\ 7.348 & 7.243 & 7.138 & 7.032 & 6.925 & 6.817 & 6.708 & 6.598 & 6.486 & 6.374 & 6.260 \\ 6.650 & 6.550 & 6.450 & 6.349 & 6.246 & 6.143 & 6.039 & 5.934 & 5.828 & 5.721 & 5.613 \\ 6.049 & 5.954 & 5.859 & 5.762 & 5.665 & 5.567 & 5.468 & 5.369 & 5.268 & 5.167 & 5.064\end{array}$

Critical slip circle

Center: $x=34.465, y=35.918$, Radius: $17.286, F=1.057$ 
STB2006 - Slope Stability

Copyright $\odot 2006$ by A. Verruijt
APPENDIX A

CALC. NO. 122633-C-004
Appendix Page 42 of 43

Page 1

David S. Messinger, P.E., Load Case 6D1

General Data

File Name

Problem Name

: David S. Messinger, P.E.

Number of Slices WCO6D1 th

: Load Case 6D1

$: 1000$

Number of Nodes $: 19^{0.000000}$

Number of Soil Polygons : 2

Figure with critical slip circle

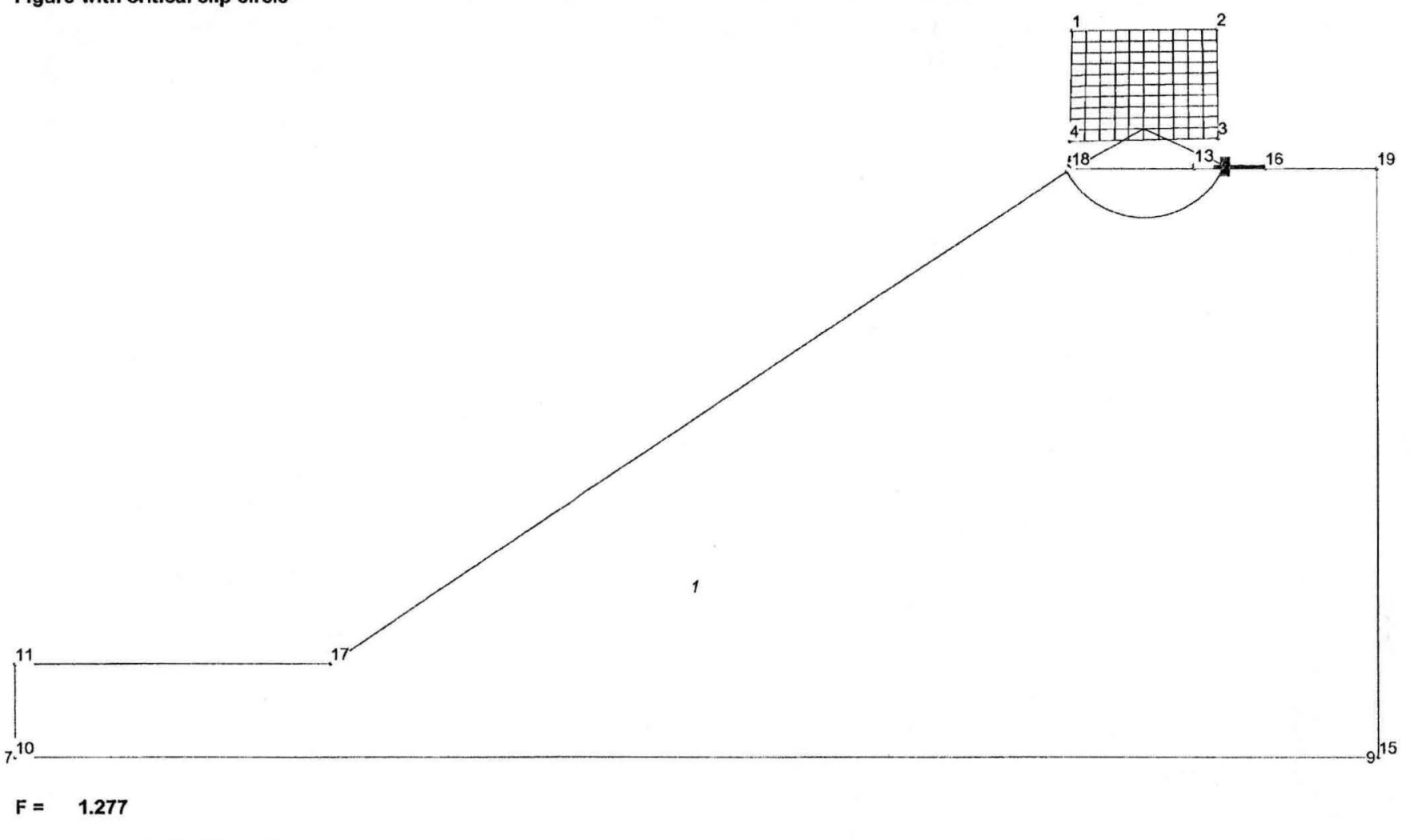

Input Data

\section{Coordinates of Nodes}

$\begin{array}{ccc}\text { Node } & x & y \\ 1 & 34.035 & 23.471 \\ 2 & 38.737 & 23.514 \\ 3 & 38.780 & 19.977 \\ 4 & 33.949 & 19.891 \\ 5 & 33.850 & 18.900 \\ 6 & 0.000 & 0.000 \\ 7 & 0.000 & 0.000 \\ 8 & 44.000 & 0.000 \\ 9 & 44.000 & 0.000 \\ 10 & 0.000 & 0.000 \\ 11 & 0.000 & 3.000 \\ 12 & 38.000 & 19.000 \\ 13 & 38.000 & 19.100 \\ 14 & 40.333 & 19.100 \\ 15 & 44.000 & 0.000 \\ 16 & 40.333 & 19.000 \\ 17 & 10.000 & 3.000 \\ 18 & 34.000 & 19.000 \\ 19 & 44.000 & 19.000\end{array}$

\section{Structure of Polygons}

Window of centers of slip circles
Nodes $1 \frac{2}{3} \quad 4$

Fixed point of all slip circles

Node 5 
STB2006 - Slope Stability

David S. Messinger, P.E., Load Case 6D1

\section{APPENDIX A}

CALC. NO. 122633-C-004

\section{Appendix Page 43 of 43}

Water Polygon

Nodes $\begin{array}{lllll}6 & 7 & 8 & 9\end{array}$

Soil Polygons

$\begin{array}{lllllllll}\text { 1: } & \text { Nodes } & 10 & 11 & 17 & 18 & 12 & 19 & 15 \\ \text { 2: } & \text { Nodes } & 12 & 13 & 14 & 16 & & & \end{array}$

Properties of Soils

$\begin{array}{ccccccccc}\text { Soil } & \begin{array}{c}W d \\ \mathrm{kN} / \mathrm{m}^{3}\end{array} & \begin{array}{c}\mathrm{Ws} \\ \mathrm{kN} / \mathrm{m}^{3}\end{array} & \begin{array}{c}\mathrm{Ko} \\ \end{array} & \begin{array}{c}\mathrm{C} \\ \mathrm{kN} / \mathrm{m}^{2}\end{array} & \begin{array}{c}\text { phi } \\ \text { degrees }\end{array} & \mathrm{P} / \mathrm{F} & \mathrm{p}=0 & \begin{array}{c}\text { cap } \\ \mathrm{m}\end{array} \\ 1 & 110.000 & 110.000 & 1.000 & 0.000 & 38.000 & \mathrm{P} & & 0.000 \\ 2 & 18214.290 & 18214.290 & 1.000 & 0.000 & 0.000 & \mathrm{P} & & 0.000\end{array}$

Output Data

Safety Factors

$\begin{array}{ccccccccccc}17.202 & 17.277 & 17.175 & 17.125 & 17.135 & 17.220 & 17.392 & 17.670 & 18.072 & 18.624 & 19.564 \\ 7.253 & 7.111 & 6.984 & 6.876 & 6.750 & 6.693 & 6.642 & 6.658 & 6.720 & 6.839 & 6.976 \\ 4.202 & 4.066 & 3.954 & 3.829 & 3.739 & 3.643 & 3.586 & 3.537 & 3.507 & 3.529 & 3.574 \\ 2.758 & 2.647 & 2.536 & 2.426 & 2.331 & 2.249 & 2.175 & 2.116 & 2.069 & 2.052 & 2.058 \\ 2.017 & 1.921 & 1.836 & 1.747 & 1.670 & 1.598 & 1.530 & 1.481 & 1.447 & 1.435 & 1.451 \\ 1.848 & 1.759 & 1.670 & 1.586 & 1.504 & 1.436 & 1.369 & 1.314 & 1.286 & 1.277 & 1.317 \\ 1.629 & 1.615 & 1.587 & 1.611 & 1.681 & 1.817 & 2.110 & 2.707 & 4.155 & 11.519 & 411.090 \\ 100.969 & 103.688 & 106.927 & 110.829 & 115.633 & 121.679 & 129.501 & 140.017 & 154.783 & 176.775 & 211.777 \\ 53.135 & 53.684 & 54.396 & 55.319 & 56.529 & 58.137 & 60.322 & 63.392 & 67.915 & 75.041 & 87.389 \\ 25.479 & 25.091 & 24.717 & 24.362 & 24.036 & 23.754 & 23.542 & 23.445 & 23.547 & 24.038 & 25.406 \\ 11.851 & 11.302 & 10.736 & 10.153 & 9.548 & 8.919 & 8.260 & 7.564 & 6.822 & 6.019 & 5.128\end{array}$

Critical slip circle

Center: $x=36.367, y=20.290$, Radius: $2.875, F=1.277$ 
Revision 2

Attachment B

Calculation 300013-C-001

B-1 


\section{Calculation Cover Sheet and Revision Summary}

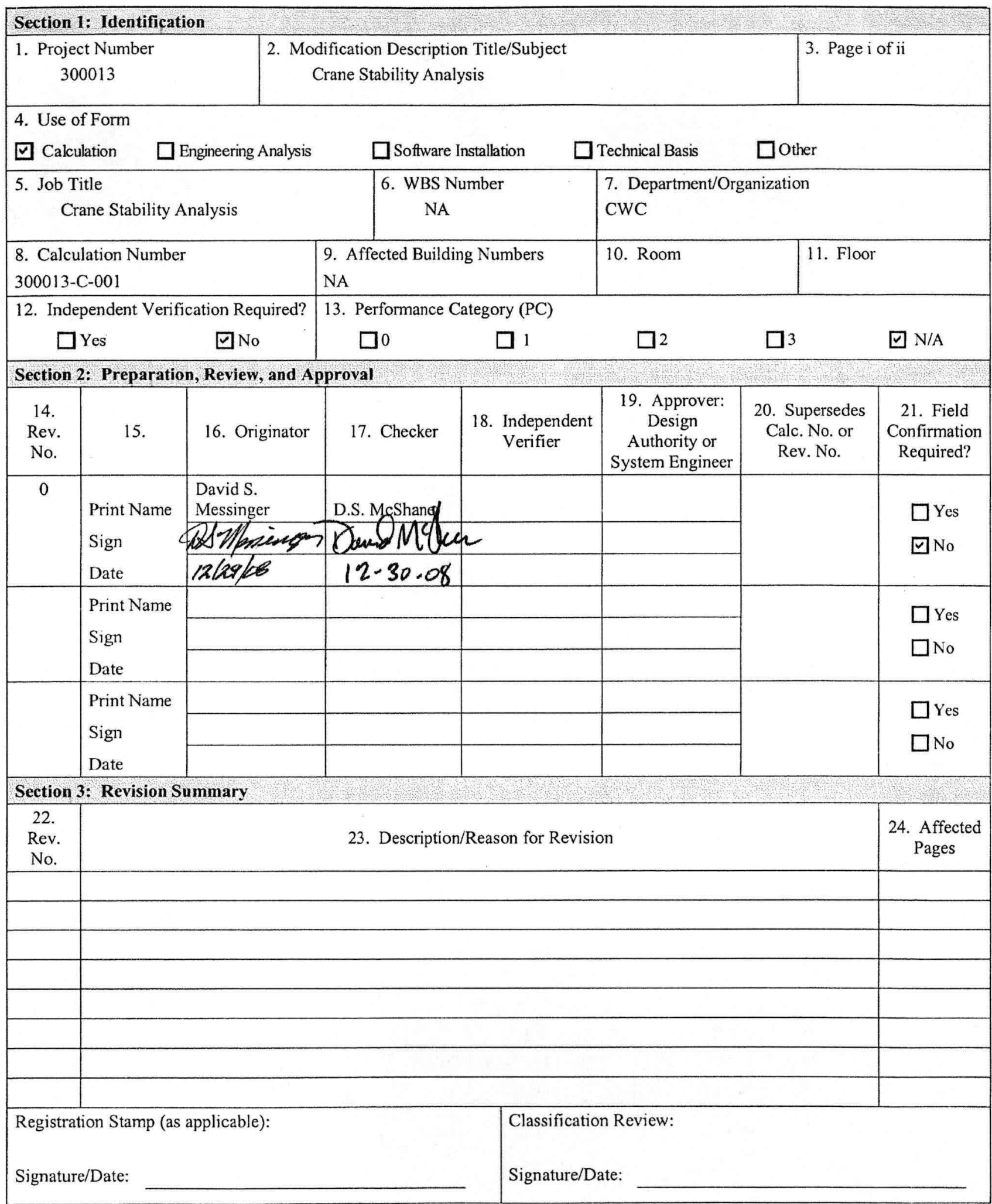




\section{Calculation/Technical Basis Sheet}

\section{Section 1: Identification}

1. Project Number

300013

2. Modification Description Title/Subject

Crane Stability Analysis

4. Calculation Number

300013-C-001

Section 2: Scope, Objective, Method, Assumptions, Technical Basis

6. Scope and Objective

This calculation was performed to support safe crane operations connected with drum retrieval in trench's at the

Central Waste Facility in the 200 West Area. There are two cranes considered in this analysis. The first is a

Manitowoc Model AT1100G12.4T0287 and the second is a Link-Belt Model LS-518.

\section{Method}

Hand calculation using Mathcad 14.0 MO11

The approach recommended by Bowels in Ref. 2, Section 4-9 will be followed.

8. Assumptions and Technical Basis

1. The soil weight is assumed to be about $110 \mathrm{pcf}$. This is a reasonable for the area of interest.

2. The angle of internal friction for the soil is 380 . (Ref. 1)

3. The dry soil is cohesion less but has an apparent cohesion of between $11 \mathrm{psf}$ and $14 \mathrm{psf}$ when freshly excavated allowing the newly excavated slope to stand at $1 \mathrm{H}: 1 \mathrm{~V}$.

4. The Link Belt Crane tracks are 44 inches wide, and exert a maximum ground loading of 20.9 psi.

5. Determine the margin of safety for soil failure for the maximum crane loads.

Section 3: Design Inputs/References

\begin{tabular}{|l|l|}
\hline 9. Ref. No. & \multicolumn{1}{|c|}{ 10. Inputs/References (with Revision and/or Date or Source) } \\
\hline 1 & Calculation No. 122633-C-004 \\
\hline 2 & Foundation Analysis and Design, 5th Edition, Bowles, McGraw Hill \\
\hline & \\
\hline Section 4: Conclusions \\
$\begin{array}{l}\text { 1. The Manitowoc crane was found to have a margin of safety of } 12 \% \text { for the maximum crane load and } 15 \% \text { for the maximum } \\
\text { expected service load at the trench. }\end{array}$
\end{tabular}
expected service load at the trench.

2. The Link-Belt crane was found to have a margin of safety of $52 \%$ with regard to maximum service load at the trench. No maximum crane loading was provided.

\section{Checkee's Note: THE chame, MODEL ATIlOOG 12.4 T0287 is Not a Manitowac Crane. This Crane is a Groóz Etare Manufactured by Grove Cranes, which is a SubsidiA2y of MANiTOWOC CRanes. Dom 12.30-08}




\section{Fluor Hanford, Inc.}

Client: CHPRC

Subject: Crane Stability Analysis for

Retrieval Work At CWC Trench

Location: CWC 200W

\section{ENGINEERING ANALYSIS}

Calc. No.:300013-C-001

Revision: 0

Page No.: 1 of 3

T.O./Job No.: 300013

Originated by: D.S. Messinger, P.E.

Checked by: David S. McShane, P.E.

\section{OBJECTIVE:}

This calculation was performed to support safe crane operations connected with drum retrieval in trench's at the Central Waste Facility in the 200 West Area. There are two cranes considered in this analysis. The first is a Manitowoc Model AT1100G12.4T0287 and the second is a Link-Belt Model LS-518.

\section{REFERENCE:}

1. Calculation No. 122633-C-004

2. Foundation Analysis and Design, 5th Edition, Bowles, McGraw Hill

\section{METHOD:}

Hand calculation using Mathcad 14.0 MO11

The approach recommended by Bowels in Ref. 2, Section 4-9 will be followed.

\section{ASSUMPTIONS AND LIMITATIONS:}

1. The soil weight is assumed to be about $110 \mathrm{pcf}$. This is a reasonable for the area of interest.

2. The angle of internal friction for the soil is $38^{\circ}$. (Ref. 1)

3. The dry soil is cohesion less but has an apparent cohesion of between 11 psf and 14psf when freshly excavater allowing the newly excavated slope to stand at $1 \mathrm{H}: 1 \mathrm{~V}$.

4. The Link Belt Crane tracks are 44 inches wide, and exert a maximum ground loading of $20.9 \mathrm{psi}$.

5. Determine the margin of safety for soil failure for the maximum crane loads.

\section{CONCLUSION:}

1. The Manitowoc crane was found to have a margin of safety of $12 \%$ for the maximum crane load and $15 \%$ for the maximum expected service load at the trench.

2. The Link-Belt crane was found to have a margin of safety of $52 \%$ with regard to maximum service load at the trench. No maximum crane loading was provided.

\section{CALCULATIONS:}

\section{COULOMB EARTH PRESSURES COEFFICIENTS:}

(Passive Pressure)

$$
\mathrm{K}_{\mathrm{p}}(\phi, \alpha, \beta, \delta):=\frac{\sin (\alpha-\phi)^{2}}{\sin (\alpha)^{2} \cdot \sin (\alpha+\delta) \cdot\left(1-\sqrt{\frac{\sin (\phi+\delta) \sin (\phi+\beta)}{\sin (\alpha+\delta) \sin (\alpha+\beta)}}\right)^{2}}
$$

$\mathrm{K}_{\mathrm{p}}(38 \mathrm{deg}, 90 \mathrm{deg}, 10 \mathrm{deg}, 20 \mathrm{deg})=21.636 \quad$ Values check against table 11-1 \& 11-2 of Bowles. (Ref. 2) 


\section{Fluor Hanford, Inc.}

Client: CHPRC

Subject: Crane Stability Analysis for Retrieval Work At CWC Trench Location: CWC 200W
ENGINEERING

ANALYSIS
Calc. No.300013-C-001 Revision: 0

Page No.: 2 of 3

T.O./Job No.: 300013

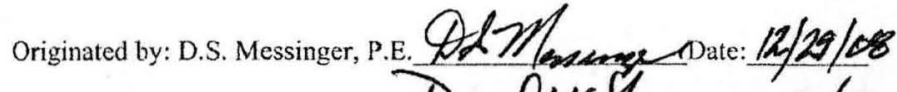

Checked by: David S. McShane, P.E. Deend $M^{c}$ Shere Date: $12 / 20 / 08$

Trench with 1-1/2:1 slope:

$\phi:=38 \mathrm{deg}$

$\mathrm{K}_{\mathrm{p}}(38 \mathrm{deg}, 90 \operatorname{deg}, 33.7 \mathrm{deg}, 38 \mathrm{deg})=22.924$

$\mathrm{K}_{\mathrm{pmax}}:=\mathrm{K}_{\mathrm{p}}(38 \mathrm{deg}, 90 \mathrm{deg}, 33.7 \mathrm{deg}, 38 \mathrm{deg})$

$\mathrm{K}_{\mathrm{p}}(38 \mathrm{deg}, 90 \mathrm{deg},-33.7 \mathrm{deg}, 38 \mathrm{deg})=1.772$

$\mathrm{K}_{\mathrm{pmin}}:=\mathrm{K}_{\mathrm{p}}(38 \mathrm{deg}, 90 \mathrm{deg},-33.7 \mathrm{deg}, 38 \mathrm{deg})$

$\mathrm{R}:=\frac{\mathrm{K}_{\mathrm{pmin}}}{\mathrm{K}_{\mathrm{pmax}}}=0.077$

From Table 4-4, $\mathrm{N}_{\gamma \mathrm{H}}:=56.1 \quad \mathrm{~b}:=4 \mathrm{ft}$

$\mathrm{B}:=4 \mathrm{ft}$

$\mathrm{L}:=\mathrm{B}$

$\gamma:=110 \frac{\mathrm{lbf}}{\mathrm{ft}^{3}}$

$\mathrm{c}:=11 \frac{\mathrm{lbf}}{\mathrm{ft}^{2}}$

$\mathrm{N}_{\mathrm{q}}^{\prime}:=48.93$

$\mathrm{N}_{\mathrm{c}}^{\prime}:=45.23$

(See Ref. 2, Sec. 4-9, Par. 2, subpar. 1-4)

Inclination factors:

$$
\mathrm{i}_{\mathrm{c}}:=1 \quad \mathrm{i}_{\mathrm{q}}:=1 \quad \mathrm{i}_{\gamma}:=1 \quad \text { No inclination }
$$

Shape factors:

$\mathrm{s}_{\mathrm{c}}:=1+\frac{\mathrm{N}_{\mathrm{q}}^{\prime}}{\mathrm{N}_{\mathrm{c}}^{\prime}}=2.082 \mathrm{~s}_{\mathrm{q}}:=1+\frac{\mathrm{B}}{\mathrm{L}} \cdot \sin (\phi)=1.616$ for a square footing at the surface, $\mathrm{s}_{\gamma}:=0.6$

$q_{b a r}:=0 \quad$ since $d=O B \quad$ Compute $N_{\gamma}^{\prime}:=\frac{N_{\gamma H}}{2}+\frac{N_{\gamma H}}{2} \cdot\left[R+\frac{b}{2 B} \cdot(1-R)\right]=43.159$

$q_{\text {ult }}:=c \cdot N_{c}^{\prime} \cdot s_{c} \cdot i_{c}+q_{b a r} \cdot N_{q}^{\prime} \cdot s_{q} \cdot i_{q}+\frac{1}{2} \gamma \cdot B \cdot N_{\gamma}^{\prime} \cdot s_{\gamma} \cdot i_{\gamma}=6.733 \frac{\text { kip }}{\mathrm{ft}^{2}}$

$\mathrm{qult} \cdot \mathrm{B}^{2}=107.724 \mathrm{kip}$

The maximum crane jack load, Jack $k_{\max }:=94.820 \mathrm{kip} \quad \operatorname{Load}_{\max }:=91.2 \mathrm{kip}$

The margin of safety for the crane with $4^{\prime} \times 4^{\prime}$ jack pad set back $4^{\prime}$ from the top of slope is:

$1-\frac{\text { Jack }_{\max }}{\left(\mathrm{qult}_{\mathrm{u}} \cdot \mathrm{B}^{2}\right)}=11.979 \%$

$1-\frac{\text { Load }_{\text {max }}}{\left(q_{u l t} \cdot B^{2}\right)}=15.339 \%$
Therefore for the assumed conditions the crane would reach its maximum capacity before the soil under the jack pad would fail.

$$
\frac{\text { qult }^{2} B^{2}}{\text { Load }_{\max }}=1.181
$$


Fluor Hanford, Inc.

Client: CHPRC

Subject: Crane Stability Analysis for Retrieval Work At CWC Trench Location: CWC 200W
ENGINEERING ANALYSIS
Calc. No.:300013-C-001

Revision: 0

Page No.: 3 of 3

T.O./Job No.: 300013

Originated by: D.S. Messinger, P.E. ALb/enmer Date:12/29/08

Checked by: David S. McShane, P.E Dund M S/lecenate: $12 / 30 / 08$

Considering the Link-Belt LS-518 tracked crane, only the width and length of track differ from the above condition.

$\mathrm{B}:=44$ in $\quad \mathrm{L}:=15 \mathrm{ft} \quad$ effective length @ $20.9 \mathrm{psi} \quad \mathrm{s}_{\mathrm{q}}:=1+\frac{\mathrm{B}}{\mathrm{L}} \cdot \sin (\phi)=1.15$

Maximum track pressure, track $_{\max }:=20.9 \mathrm{psi}$

$q_{\text {ult }}:=\mathrm{c} \cdot \mathrm{N}_{\mathrm{c}}^{\prime} \cdot \mathrm{s}_{\mathrm{c}} \cdot \mathrm{i}_{\mathbf{c}}+\mathrm{q}_{\mathrm{bar}} \cdot \mathrm{N}_{\mathrm{q}}^{\prime} \cdot \mathrm{s}_{\mathrm{q}} \cdot \mathrm{i}_{\mathrm{q}}+\frac{1}{2} \gamma \cdot \mathrm{B} \cdot \mathrm{N}_{\gamma}^{\prime} \cdot \mathrm{s}_{\gamma} \cdot \mathrm{i}_{\gamma}=2.013 \times 10^{5} \mathrm{lb} \cdot \mathrm{s}^{-2} \cdot \mathrm{ft}^{-1}$

$\mathrm{qult}_{\mathrm{ul}} \cdot \mathrm{B}^{2}=2.707 \times 10^{6} \mathrm{lb} \cdot \mathrm{s}^{-2} \cdot \mathrm{ft}$

Assume the margin of safety for the tracked crane is $1-\frac{\text { track }_{\max }}{\text { qult }_{\text {alt }}}=51.908 \%$

or the factor of safety is $\frac{\mathrm{qu}_{\mathrm{ult}}}{\text { track }_{\max }}=2.079$ 
Link-Belt Constructon Equipment Co., Lexington, Kentucky - LS-518

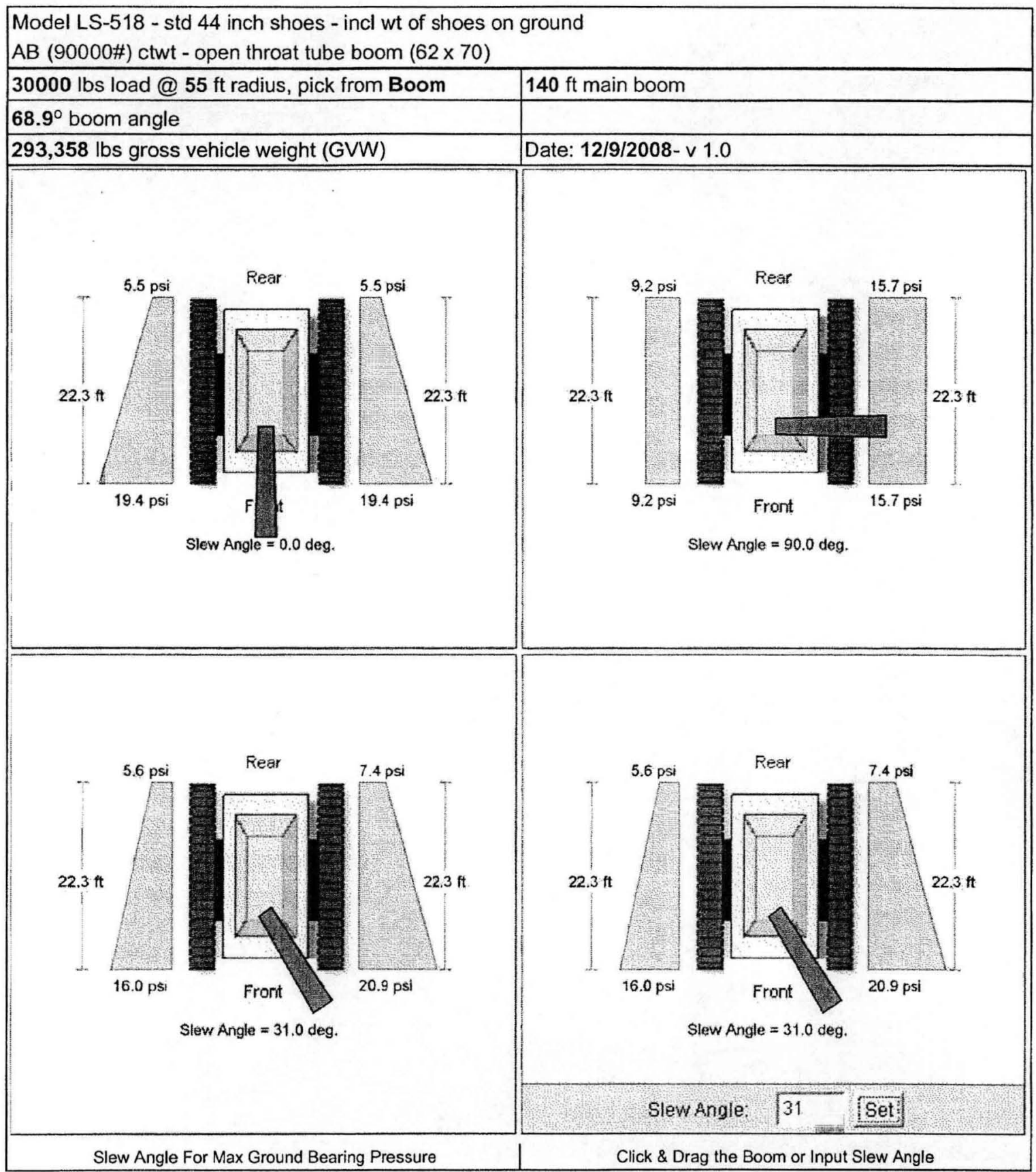

\section{CAUTION: DO NOT USE FOR CAPACITIES!}

User to consult the crane rating manual or capacity plate supplied with the machine for input values used in these ground bearing reaction calculations. Do not exceed allowable lifting capacities for configured machine setup.

$$
<\text { - Go Back }
$$


Messinger, David S

From:

Sent:

To:

Subject:

Attachments:

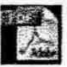

at1100g12.4to

.7 (sm).pdf (4 M
McShane, David S

Thursday, December 11, 2008 1:02 PM

Messinger, David S

FW: Crane Pad Loads

at1100g12.4to287 (sm).pdf

-..--Original Message-..--

From: Yanochko, Ronald M (Ron)

Sent: Wednesday, September 24, 2008 12:20 PM

To: McShane, David S

Subject: FW: Crane Pad Loads

For your use.

-...-Original Message-...-

From: Myers, Douglas W [mailto:Douglas.Myers@manitowoc.com]

Sent: Wednesday, September 24, 2008 12:13 PM

To: Yanochko, Ronald M (Ron)

Subject: FW: Crane Pad Loads

Ron,

This took a long time, but below is information on your AT1100 pad load request.

Regards,

Doug Myers

Product Specialist

Grove

Manitowoc Crane Group

Phone 717-593-5035

Fax 717-593-5104

Email - douglas.myers@manitowoc.com

-.---Original Message--.--

From: Hollingshead, Neil J

Sent: Wednesday, September 24, 2008 1:49 PM

To: Myers, Douglas $W$

Subject: Fw: Crane Pad Loads

Not sure if you got this

Neil

Neil Hollingshead

Manitowoc Cranes

Global Product Manager

All Terrain \& Rough Terrain Cranes

+44 (0) 7894595484 (mobile)

+44 (0) 1915201013 (office)

neil.hollingshead@manitowoc.com

Message sent by BlackBerry 
---- Original Message -...-

From: Borsberry, David J

CALC 300013-C-001

APPENDIX Page 3 of 10

To: Bage, Michael $\mathrm{T}$; Hollingshead, Neil J

Sent: Tue Sep 23 13:47:49 2008

Subject: RE: Crane Pad Loads

Mike,

The attached jack load graph for this model shows a max jack point load of 43 tonnes (94820 pounds).

This is with the 27300 pound ballast lifting 25698 pounds at 55 feet radius.

The graphical method is only a guide and is not an exact result.

It will usually err to the high side but is the only info we can officially provide.

For your info a calculation programme devised by Sunderland Engineering is available.

This was never officially issued but it is oK to help verify the graphical results.

The calculation for this crane shows the worst position is over the rear corner.

The rear corner jack point load for the 25662 pounds load at 55 feet radius is 41.31 tonnes (91100 pounds).

The same jack with the 25698 pounds load at 55 feet radius is 41.37 tonnes (91200 pounds).

Dave

From: Bage, Michael T

Sent: 21 September 2008 08:54

To: Hollingshead, Neil J

Cc: Borsberry, David J

Subject: RE: Crane Pad Loads

Neil,

I guess the only person that can help with this is Dave Borsberry.

I copy him to see what can be done.

Thanks and regards, Mike. 
From: Hollingshead, Neil J

Sent: 21 September 2008 11:39

To: Bage, Michael T

Subject: FW: Crane Pad Loads

Try again as first mail bounced back.

Best regards

Neil

Neil Hollingshead

Manitowoc Cranes

Global Product Manager

All Terrain \& Rough Terrain Cranes

+44 (0) 7894595484 (mobile)

+44 (0) 1915201013 (office)

neil.hollingshead@manitowoc.com

From: Hollingshead, Neil J

Sent: 18 September 2008 13:29

To: Bage, Mike

CC: Myers, Douglas w

Subject: FW: Crane Pad Loads

Mike

Do you know how this will be handled ?

Neil Hollingshead

Manitowoc Cranes

Global Product Manager

All Terrain \& Rough Terrain Cranes

+44 (0) 7894595484 (mobile)

+44 (0) 1915201013 (office)

neil.hollingshead@manitowoc.com

From: Myers, Douglas W 
Sent: 18 September 2008 13:19

To: Hollingshead, Neil J

Neil,

I know this is not your area, but who is left that can help with a pad load request for an AT1100. All the guys in the UK are gone. Any idea??

Doug Myers

Product Specialist

Grove

Manitowoc Crane Group

Phone 717-593-5035

Fax 717-593-5104

Email - douglas.myers@manitowoc.com <mailto:douglas.myers@manitowoc.com>

From: Yanochko, Ronald M (Ron) [mailto:Ronald_M_Ron_Yanochko@RL.gov]

Sent: Tuesday, September 16, 2008 6:30 PM

To: Myers, Douglas $\mathrm{W}$

Cc: McShane, David S

Subject: Crane Pad Loads

This is a follow-up to our telephone conversation, earlier this day.

Please provide outrigger pad loads for the following crane information, as discussed.

Crane Description: Grove All-Terrain 110 Ton

Crane Model No.: AT1100 All-terrain hydraulic crane

Serial No.: 850430

Case No. 1 Case No. 2

Counter weight to be used: 27,300 lbs.
27,300 lbs. 
CALC 300013-C-001

Outrigger Spans:

$25^{\prime}$ - $0 "$ x 25' - 0"

Boom Length:

100 - 4"

Boom Angle:

48 degrees

Radius :

$55^{\prime}-0^{\prime \prime}$

Lifted Load:

$25,662.0 \mathrm{lbs}$.

Pad Diameter:

28 inches $25^{\prime}-0^{\prime \prime} \times 25^{\prime}-0 "$

$100^{\prime}-4 "$

57.3 degrees

$55^{\prime}-0^{\prime \prime}$

25, 698 lbs.

28 inches 


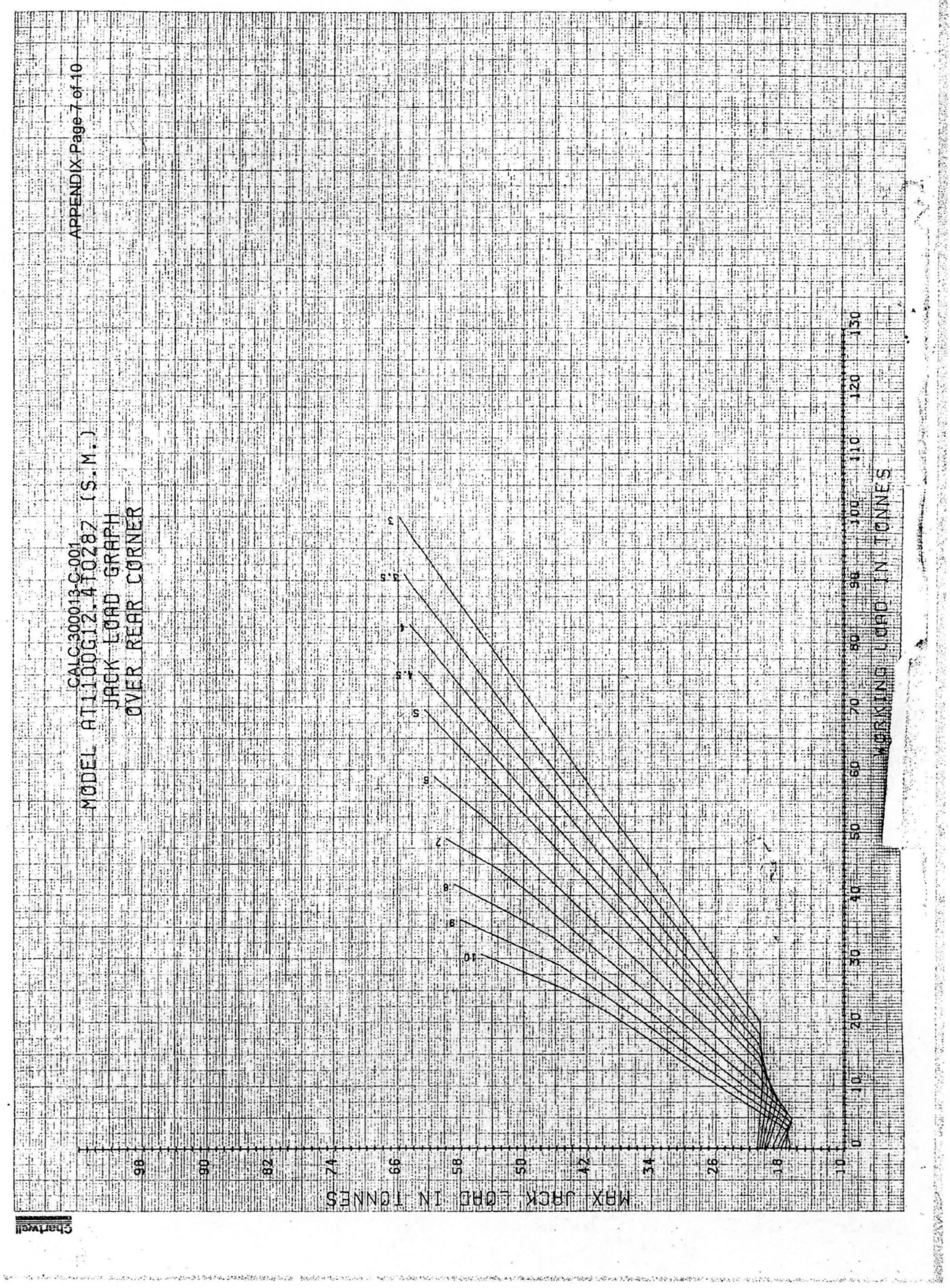




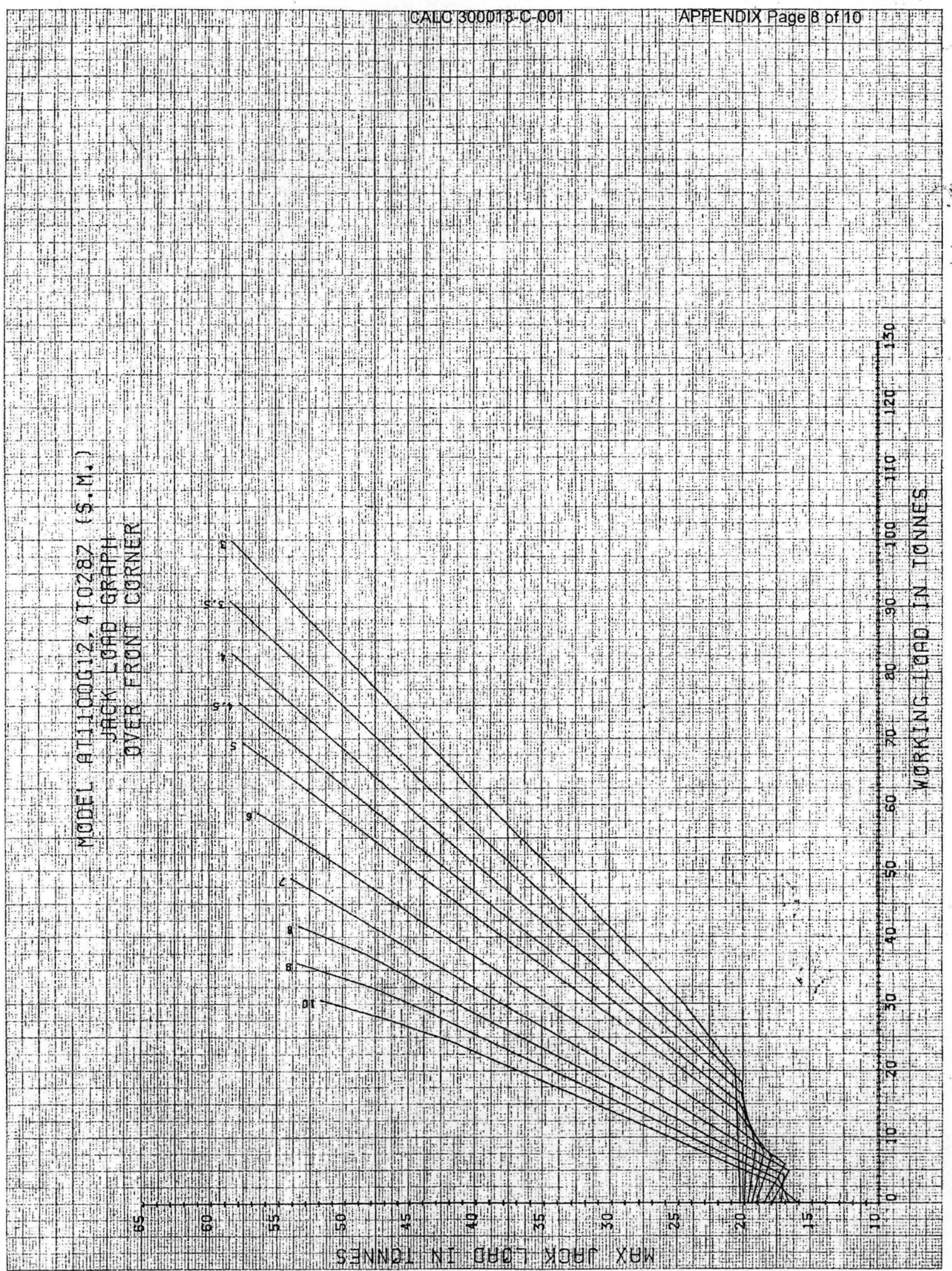


MOBEL AT $1100 G 12.4$ TO287 (S.M.) JACK LOAB GRAPH

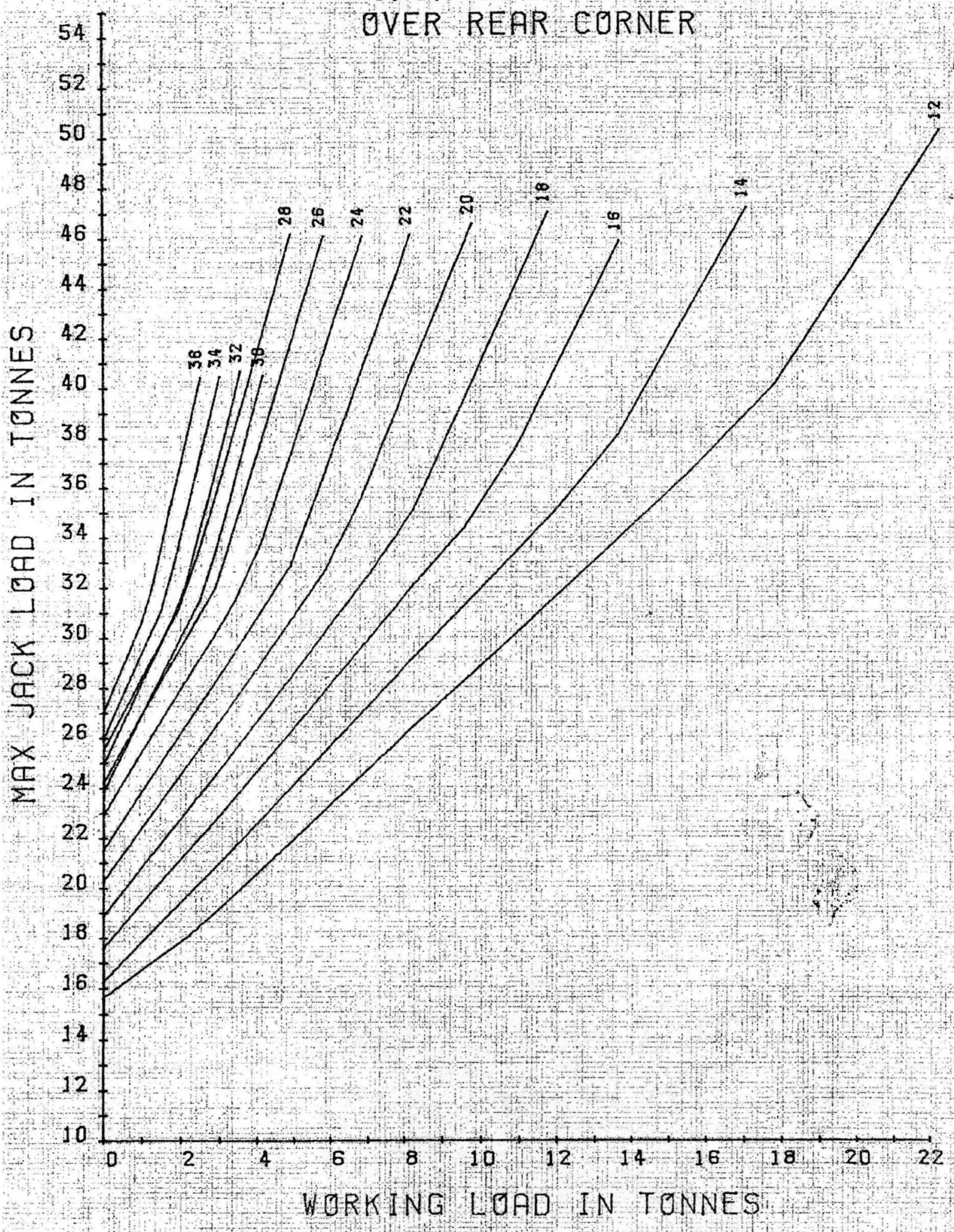




\section{MODEL AT $1100 G 12.4 T 028$ ) (S.M.) JACK LOAD GRAPH OVER FRONT CORNER}

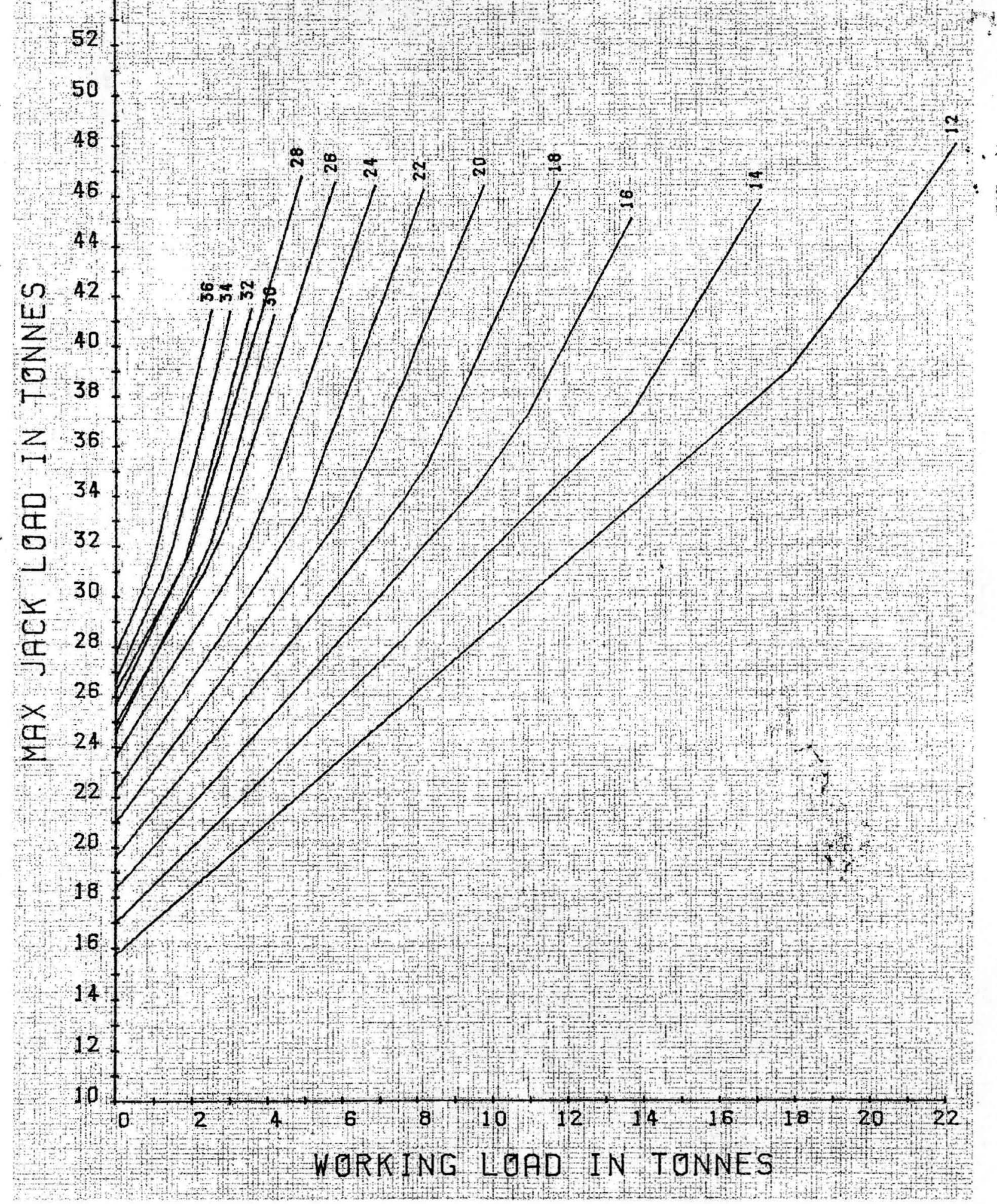

